\title{
Chalés paulistanos
}

\section{Eudes Campos ${ }^{1}$}

RESUMO: $\bigcirc$ presente artigo estuda a origem, o desenvolvimento e a decadência, no ambiente urbano paulistano, de um tipo de construção denominado chalé. Fruto do Romantismo do século XIX, e muito popular no último terço do oitocentismo, o chalé assumiu alto valor simbólico - embora de significado ambíguo -, por estar ligado tanto à noção de uma idealizada vida campestre, quanto à de modernidade técnica, que então se introduzia em São Paulo. Popularizou-se em razão da facilidade de importação de material de construção industrializado e expandiu-se durante a onda construtiva que atingiu a capital paulista a partir do ano de 1875. Em fins do Império, foi objeto de medidas restritivas municipais por ter sido considerada desregrada sua proliferação no espaço urbano da cidade. E, a partir do começo do século $X X$, a transformação do gosto, as reformas urbanísticas então encetadas no Centro paulistano (1902-1914) e o desejo de construir um novo cenário urbano segundo o sistema de valores e os interesses das camadas hegemônicas contribuíram para o seu gradativo desaparecimento. PALAVRAS-CHAVE: Chalé. Arquitetura. Pitoresco. Ecletismo. Habitação. São Paulo.

ABSTRACT: This article studies the origins, flourishment and decadence of a certain style of building, known as swiss cottages or chalets, in the urban environment of Sao Paulo. Its source is found in $19^{\text {th }}$ century romanticism and in the last quarter of the eighteen hundreds this kind of construction was very popular. At this time it had taken on a high symbolic value - although of an ambiguous nature - for it was both intimately associated to an idealization of country life and to technological modernity, which was then being ushered in the city of Sao Paulo. It became very popular on account of the availability of industrialized construction material for importation and it expanded during a construction boom that attained the city of Sao Paulo, after 1875. On the downfall of Brazilian monarchy, it gradually disappeared, as it became the object of restrictive measures from the local county, which considered its proliferation unruly. From the beginning of the XXth century, there was a change in public taste and urban reforms were implemented in downtown Sao Paulo (1902 to 1914), which was followed by a desire for a new urban scene, more in touch with the system of values and interests of hegemonic sectors of the local political elite.

KEYWORDS: Swiss Cottage. Architecture. Picturesque. Eclectism. Habitation. Sao Paulo.
1. Arquiteto, doutor pela FAU/USP e pesquisador do Arquivo Histórico Municipal Washington Luís, Departamento do Patrimônio Histórico.E-mail:<eudes_mello@ hotmail.com>. 
2. Obras consultadas sobre o assunto: Robin Middelton \& David Watkin (1980, p. 33 e ss); Claude Mignot (1983, p.13 e ss); e Nikolaus Pevsner (1969, p.77 e ss)
Considerada uma das modalidades de edificação mais populares na cidade de São Paulo durante o último terço do século XIX, o chalé até hoje não mereceu um estudo aprofundado, à altura de sua importância. Este artigo é, portanto, uma tentativa de fazê-lo. Embora bastante pormenorizado, deve ser visto como uma contribuição despretensiosa, já que estamos ciente de que não poderemos, por ora, responder a todas as instigantes perguntas que o tema suscita. Como plano de abordagem, traçaremos primeiro, em linhas gerais, a trajetória de criação e desenvolvimento do chalé no Exterior, e, a seguir, identificaremos alguns exemplares paulistanos do século XIX, que serão analisados, sempre que possível, do ponto de vista estilístico, construtivo e programático.

Com a crescente popularização do chalé em São Paulo, não só houve uma disseminação de seus elementos decorativos por outros tipos de construção, como também sua presença acabou por perder o sentido das conveniências. Adotado a princípio como um tipo edilício apropriado a casas de subúrbio, adaptou-se em seguida às atividades de entretenimento e recreação e às atividades ligadas à saúde, pois os proprietários das primeiras clínicas médicas procuravam lugares retirados e salubres para sua instalação. Por fim, os elementos arquitetônicos mais característicos dos chalés passaram a se espalhar pelo centro da cidade, freqüentando modestos prédios comerciais ou mistos, de clara fisionomia popular. Foi então necessário criar disposições normativas municipais que disciplinassem a ocorrência desordenada desse tipo de edificação.

Como praticamente nenhum exemplar de chalé sobreviveu na cidade, para estudá-lo foi indispensável recorrer à documentação iconográfica e à documentação escrita, em geral constituída de anúncios de jornais. À semelhança de nossos estudos anteriores, também lançamos mão, aqui, de farta documentação custodiada pelo Arquivo Histórico Municipal Washington Luís (AHMWLL), da Prefeitura da Cidade de São Paulo - instituição que detém fontes arquivísticas (leis, disposições camarárias e documentos administrativos, entre outras) de consulta obrigatória para todos que pretendem estudar a história da arquitetura paulistana - e das coleções de imagens pertencentes ao Museu Paulista (MP) e à Divisão de lconografia e Museus (DIM), do DPH.

pitoresco e a recuperação estética das construções vernáculas

A arquitetura doméstica burguesa da Europa no século XIX tem suas raízes arraigadas no movimento pitoresco inglês da primeira metade dos Setecentos. Foi a arte dos jardins pitorescos, desenvolvida nas grandes propriedades rurais aristocráticas inglesas, que promoveu a revalorização do ambiente natural, em que os exemplares de arquitetura deviam harmoniosamente se integrar ${ }^{2}$.

O jardim inglês contrapunha-se ao artificialismo formal do jardim à francesa, e sua origem mais remota recuava aos precedentes da ltália do 
Renascimento. Seu amor às irregularidades e sinuosidades naturais (sharawaggi), no entanto, provinha da arte dos jardins do Extremo Oriente ${ }^{3}$. A paisagem pitoresca inglesa nasceu, assim, da fusão da jardinagem, com a pintura, a topografia, a poesia, o exotismo, a arqueologia e a arquitetura. $\bigcirc$ jardineiro inglês tinha como objetivo criar um esplêndido cenário de aparência natural, mas cheio de efeitos evocativos, que fizessem vibrar a sensibilidade dos visitantes.

Os vários elementos que compunham esse gênero de jardinagem, os bosquetes de aspecto selvagem, eventualmente inspirados em quadros de Salvador Rosa (1615-1673), os lagos, os riachos, os templetes de estilo palladiano, as pontes, as grutas, as ruínas clássicas ou medievais - falsas ou verdadeiras -, as cenográficas aldeias montadas com construções rústicas inspiradas nas da campagna romana, por vezes retiradas de quadros de Claude Lorrain (1600-1682) e de Gaspard Poussin (1615-1675), deviam interagir intensa e harmoniosamente, criando um quadro pastoril, literário e culto, para deleite dos proprietários e seus convidados.

Foi sob a influência dessas circunstâncias culturais que, por exemplo, o arquiteto neoclássico Richard Mique (1728-1794) construiu, entre 1783 e 1786, à beira de um lago artificial, o famoso hameau nos jardins do Petit Trianon, em Versalhes, para uma fútil Maria Antonieta, que tentava fugir do ambiente opressivo da Corte lao que se supõe, ele o fez sob o efeito da atmosfera evocativa presente na obra do pintor Hubert Robert, 1733-1808, um artista querido da realeza francesa). Entregando-se à anglomania em moda na época, a soberana passava temporadas no local com seus cortesãos mais próximos, vestida de camponesa e tirando leite de vacas, com baldes de porcelana de Sèvres, pintados como se fossem de madeira e decorados com cabeças de faunos.

Na década de 1790 e nos anos imediatamente seguintes, foram publicados na Inglaterra os mais importantes textos sobre a estética do Pitoresco, de autoria de W. Gilpin (Three essays on picturesque beauty, 1794), Uvedale Price (Architecture and buildings connected with scenery, 1794-1798; Essay on the picturesque, 1810) e R. Payne Knight (An analytical inquiry into the principles of taste, 1805). E já em 1809, na França napoleônica e neoclássica, saía, de J. C. Kraft e P. L. F. Dubois, o álbum intitulado Productions de plusiers architectes français et étrangers relatives aux jardins pittoresques et aux fabriques de divers genres qui peuvent entrer dans leurs composition, em que eram ilustrados os principais tipos de construções decorativas (folies) destinadas a jardins: o pavilhão indiano, o pagode chinês, a capela gótica, o templo egípcio e a casa campestre à italiana.

Na Inglaterra, porém, a estética do Pitoresco acarretaria resultados mais conseqüentes, contribuindo: para a recuperação estética dos edifícios e das ruínas medievais; para a retomada dos antigos castelos ingleses como modelo de moradia campestre para a aristocracia rural; para o desenvolvimento de projetos residenciais de acordo com composições assimétricas e plantas irregulares, a fim de fundir as construções no ambiente paisagístico, e para a concepção de novos tipos construtivos de arquitetura doméstica burguesa,
3. A palavra sharawadgi (mencionada pela primeira vez no livro de William Temple, Gardens of Epicurus, datado de 1685 e publicado em 1692) ou sharawaggi (como Horace Walpole chamou depois) é uma palavra de origem etimológica obscura. Chegou a ser considerada corruptela de um termo chinês, que significaria "graça desordenada" ou "graça descuidada".Alguns estudiosos afirmaram, contudo, que esse termo foi simplesmente inventado por Temple, uma espécie de chinoiserie literária, para definir a qualidade máxima dos jardins chineses, a sua beleza peculiar, que era a de reproduzir as irregularidades da Natureza por intermédio das mãos humanas, de maneira a um tem po minuciosa e fantástica. Ver: A note on Sharawaggi, em Nikolaus Pevsner (1969,p.103 a109). Na Internet, entretanto, localizamos umas considerações recentes sobre a etimologia da palavra sharawaggi. Trata-se, ao que parece, de uma antiga palavra japonesa, ainda hoje sobrevivente no dialeto de Kyushu:shorowaji,que é usada quando as duas metades de uma coisa não combinam ou não se casam, ou seja, quando há assimetria ou irregularidade em algo. Ver: SHARAWAGGI. Disponível em:<http://.www.languagehat.com/archives/001729 php>. Acessado: fev. 2008 
4. Ver Petra Lamers-Schütze (2003, p. 288-295, para Boffrand; p. 312-317, para Peyre).

5.Ver A. J. Downing ([1969], passim). baseados na arquitetura vernácula, o cottage (pequena construção doméstica de tipo campestre) e a vila suburbana.

Foi no ambiente rural inglês que o estilo pitoresco nasceu, mas o arquiteto John Nash (1752-1835) logo deu provas de que podia ser usado também no contexto urbano. Em 1811 , ergueu os primeiros exemplares de casa suburbana com jardins (Blaise Hamlet, perto de Bristol, Gloucestershire, Inglaterra). As edificações tinham inspiração decididamente rústica; foram erguidas com técnicas de construção rudimentares e, às vezes, cobertas com telhados de colmo.

Paralelamente ao desenvolvimento da estética pitoresca na Inglaterra durante o século XVIII, temos as teorias estéticas francesas, resultantes do subjetivismo e do psicologismo. Como resultado dessas teorias, surgiv a estética arquitetural que falava ao espírito e comovia a alma do espectador, fundamentada no jogo regrado de associações de idéias (histórico-literárias e ético-religiosas).

arquiteto francês Germain Boffrand (1667-1756), em 1745, afirmava que a arquitetura devia falar aos homens como as palavras de uma língua, enquanto Marie-Joseph Peyre (1730-1785), em 1765, defendia a idéia de que a arquitetura era capaz de suscitar emoções fortes ${ }^{4}$. Duas tendências arquitetônicas que se apoiaram nesses novos ideais estéticos foram o Pitoresco e o Historicismo, ambas expressando o desejo de evasão romântica, surgida como reação ao racionalismo moderno e à realidade cada vez mais dura da civilização paleoindustrial.

No final da ldade Clássica reconheceu-se a "expressividade simbólica" da arquitetura por intermédio da teoria do "caráter" dos edifícios, ou seja, à arquitetura era reconhecida a capacidade de transmitir idéias abstrałas num nível acima de sua realidade material. À beleza da forma deveria sobrepor-se a "beleza relativa", também chamada "beleza de expressão", que é aquela que comunica idéias morais, sociais e intelectuais. De todos os tipos de arquitetura, segundo os teóricos, era a arquitetura doméstica que mais se prestava a expressar os sentimentos sociais e morais do homem. As concepções românticas sobre a arquitetura residencial defendiam, portanto, a ampla utilização do ecletismo tipológico-estilístico, afirmando haver sempre um estilo vernáculo ou histórico idôneo para cada tipo funcional de arquitetura doméstica, urbana ou campestre, e para cada tipo de temperamento e modo de vida do proprietário.

Em meados do século XIX, todo esse aparato teórico voltado para a arquitetura doméstica já se achava consolidado, e o arquiteto A. J. Downing (1815-1852), em seu grande sucesso editorial, The architecture of the country houses (1850), predispôs-se a divulgá-lo nos EUA por meio de projetos arquitetônicos, a fim de convencer, tanto os arquitetos norte-americanos quanto os seus clientes, das vantagens da arquitetura doméstica pitoresca de caráter historicista que então imperava na Europa ${ }^{5}$. 
Segundo o historiador Claude Mignot, foi P. R. Robinson, em seu álbum Rural Architecture or a Serie of Designs for Ornamental Cottages (cuja primeira edição data de 1822 e a quarta de 1836), quem propôs, pela primeira vez, um modelo de construção rural suíça (swiss cottage), desenhado em 1816, no caminho de retorno da ltália (estampa 8), como passível de ser adotado pelas pequenas casas de campo inglesas ${ }^{b}$. Não conhecemos tal modelo, mas dada a precocidade da data em que foi proposto, só podemos imaginá-lo conservando a maioria das características arquitetônicas originais, entre elas a singela volumetria, muito acessível à sensibilidade da cultura clássica então dominante.

Em sua forma vernácula, era uma construção de madeira bastante simples, típica da região rural da Suíça francesa. Em geral, possuía planta retangular e telhado de duas águas, com suave inclinação, disposto de modo a voltar uma das empenas para a frente. Notabilizava-se, sobretudo, pela profusa ornamentação externa, executada por meio de entalhes rudemente falquejados em determinadas partes da construção, como as mãos-francesas que sustentavam os largos beirais, as bordas de portas e janelas e as tábuas que formavam o peitoril do balcão do primeiro andar.

O renomado crítico de arte inglês John Ruskin (1819-1900), em sua obra de juventude The Poetry of Architecture (1838), informava que, na verdade, havia dois tipos de construção campestre suíça: o abrigo temporário de verão no alto dos Alpes, usado para a proteção dos camponeses que levavam o gado para pastar nas montanhas, conhecido sob o nome de chalet, e a casa rústica situada no fundo do vale, habitada durante o rigoroso inverno, o swiss cottage (Figura 1). Ruskin fez uma comovente descrição desse pitoresco e agradável

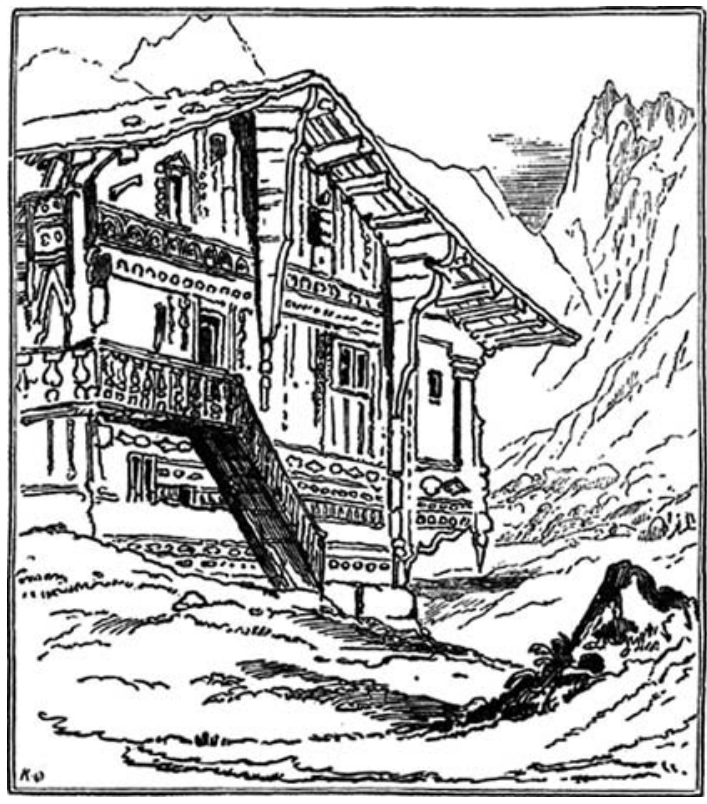

Figura 1 - John Ruskin. Chalé suíço, 1837. Ilustração. The poetry of Architecture, 1838. p. 25. 
7.Ver John Ruskin (1838, p. 25).

8. Giovanna Rosso del Brenna $(1987$, p. 39, n. 6$)$

9. Ver A. J. Downing ([1969], p. 151, fig. 63).

10. Ver Osbourne House tipo de construção campestre e, já naquele tempo, alertava as famílias inglesas de classe média para o fato de que aquela pequena construção enfeitada em que viviam - rodeada de jardinzinhos, com um tanque com repucho onde havia um peixe dourado e dois ou três patos, entre outros detalhes - nada tinha de fato do swiss cottage verdadeiro?.

Giovanna Rosso del Brenna ${ }^{8}$ lembra-nos, por sua vez, que o interesse pelo chalé suíço aumentou muito na Europa dos Oitocentos depois que foi publicado o álbum Architecture suisse ou choix de maisons rustiques des Alpes du canton de Berne, em 1844, da autoria de Charles-Adolf de Graffenried e Ludwig von Sturler (Figura 2). O próprio A. J. Downing, em sua obra já citada, incluiu uma gravura (tirada de um jornal britânico da década de 1840) que patenteava a curiosidade do público inglês por esse tipo de construção rural ${ }^{9}$.

E não se deve esquecer ainda que até a família real britânica manifestou grande apreço pelo chalé, ao ser providenciada pelo príncipe-consorte Alberto (1819-1861), marido da rainha Vitória (1819-1901), a compra e transferência de uma construção rural verdadeira da Suíça (o Osborne Cottage), reconstruída (1853-1854) nos jardins da Osborne House (1 846-1 851 1), East Cowes, na ilha de Wight, para que os seus jovens filhos pudessem brincar nela, adquirindo noções práticas de economia doméstica ${ }^{10}$.

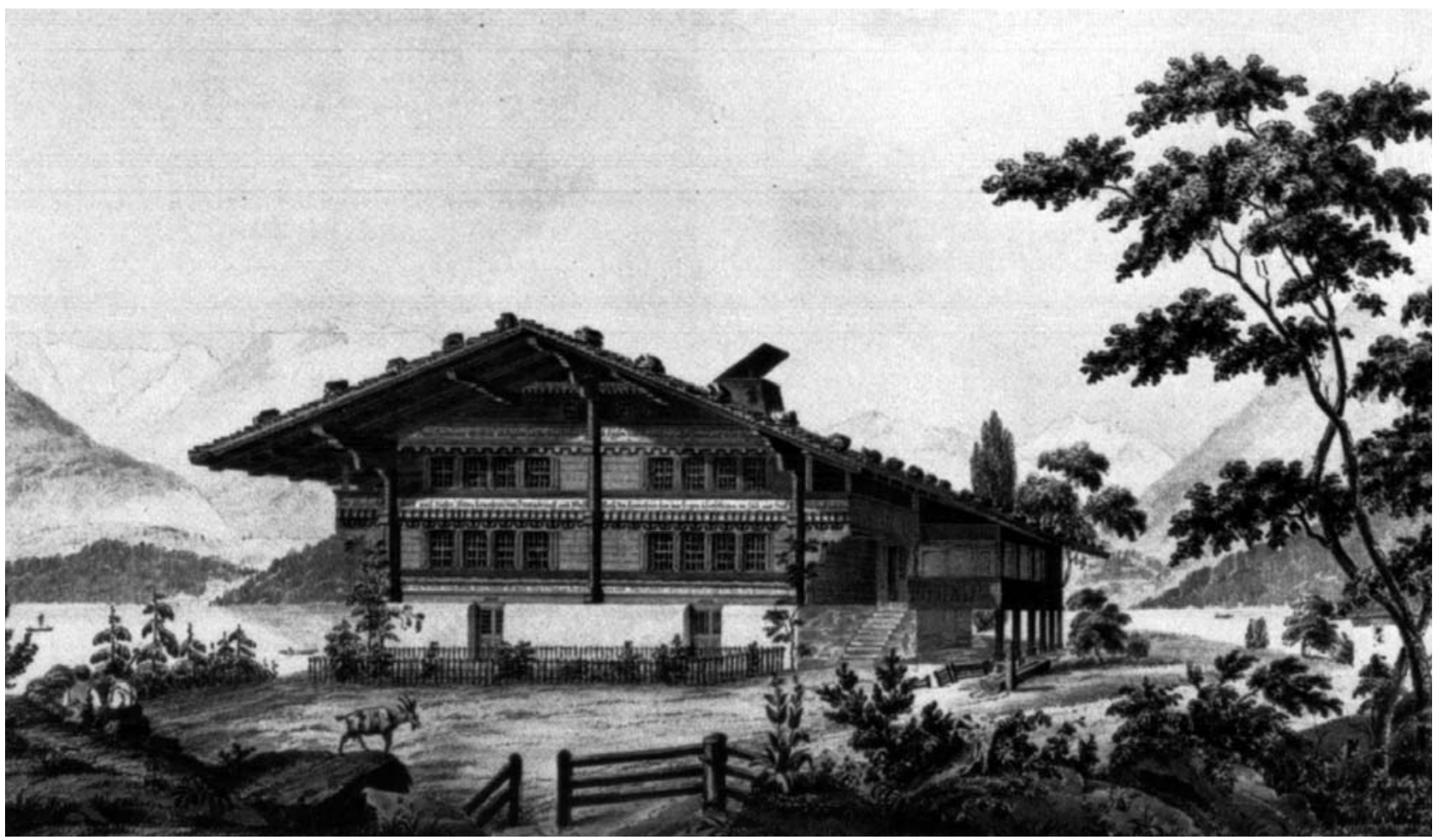

Figura 2 - Charles-Adolf de Graffenried e Ludwig von Sturler. Chalé em Iseltwald, 1843. Ilustração. Architecture suisse ou choix de maisons rustiques des Alpes du canton de Berne, 1844. 
Como podemos observar pelo comentário feito por Ruskin em seu The Poetry of Architecture, a construção suiça autêntica, rústica mas pitoresca, acabou por se transformar por completo nas mãos dos arquitetos eruditos europeus. Algumas de suas características tradicionais simplesmente não se amoldavam aos costumes burgueses de então, nem aos novos conceitos de higiene e conforto. Pretendendo introduzir a arquitetura romântica européia nos EUA, ainda sob a atmosfera do Neoclassicismo nos meados do século XIX, o arquiteto A. J. Downing citava dois dos hábitos campestres incompatíveis com o comportamento civilizado contemporâneo: o costume de os camponeses suiços acolherem seus animais domésticos no pavimento térreo das casas e o de disporem grandes pedras sobre as coberturas a fim de evitar que as telhas deslizassem"1.

Na verdade, o que acabaria por sobreviver dessas construções rurais primitivas na arquitetura erudita oitocentista seria tão-somente o teto de duas águas, dispostas com grande angulação (Ruskin fala em 155\%), com oitão frontal e largos beirais, originalmente sustentados por grandes mísulas ou mãos-francesas. A decoração principal desse tipo de telhado, no entanto - constituída por abas beirais profusamente recortadas, os chamados lambrequins, e pelos torneados pináculos, inseridos nos pontos extremos da cobertura -, que tanta personalidade conferia aos chalés ecléticos de meados do oitocentismo, não pertencia de fato à construção rústica de estilo alpino.

Já em 1838, Ruskin havia chamado a atenção para as intromissões ornamentais indevidas que apareciam nas imitações inglesas daquele tempo. Em relação aos lambrequins, foi taxativo. Não existiam na construção original. "No ornamental work is ever employed to disguise the beams of the projecting part of the roof, nor does any run along its edges"12, garantiu.

Esse tipo de ornamentação fora copiado da existente nas velhas construções domésticas medievais inglesas, e, com o desenvolvimento do Ecletismo, tal ornamentação acabou incorporada à versão erudita do chalé. Na obra acima citada de Downing, por exemplo, as vergeboards (abas beirais ou testeiras), ricamente entalhadas, às vezes estavam ausentes dos exemplares arquitetônicos

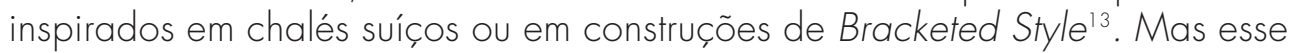
elemento decorativo era freqüente nas composições arquitetônicas baseadas no Gothic Style e no Pointed Style, um estilo medievalizante, não especificamente gótico, que incluía as edificações do período Tudor (séc. XV e XVI) ${ }^{14}$.

Segundo as prescrições de Downing, abas testeiras decoradas só deveriam comparecer em exemplares arquitetônicos mais faustosos executados nesse estilo, como as vilas suburbanas, e não em meros cottages. Aliás, Downing era muito exigente quanto à aparência das vergeboards. Deveriam ser entalhadas em tábuas de pinho de duas e meia a três polegadas de espessura (seis a sete centímetros aproximadamente), para ter aparência sólida e legítima, e, assim, produzir um efeito rico e pitoresco. E nunca se assemelhar às vulgares imitações feitas com tábuas finas, que já então se faziam para a decoração de pequenos cottages e cujo aspecto - a seu ver excessivamente frágil, arrebicado e de mau gosto - era deplorado pelo arquiteto norte-americano ${ }^{15}$. Embora condenáveis por sua frivolidade, segundo critérios estéticos de importantes arquitetos da
11.VerA.J.Downing ([1969], p. 124; 152).

12.Ver John Ruskin (1838, p. 33).

13.VerA.J.Downing ([1969], p. 113 , fig. 37 ; p. 124, fig. 47).

14. Idem, p. 296, fig. $128 ;$ p. 300 , fig. 130 ; p. 305 , fig. 134 , por exemplo.

15.Idem,([1969],p.105;328; 352). 
16.A obra de Downing, já citada,é toda ela muito rica em considerações desse tipo.

17.John Ruskin (1853,p. 18). época, os rendilhados lambrequins e os pináculos graciosamente torneados, uma vez integrados no telhado de duas águas com empena frontal, tornaram-se símbolo de um idealizado mundo rural, remoto e pleno de bucolismo. E logo, na segunda metade do século XIX, esses exemplares se espalharam pelos subúrbios das modernas cidades estrangeiras, sempre associados aos mais diferentes estilos historicistas catalogados pelas academias, graças às facilidades oferecidas em virtude da fabricação industrializada de muitos de seus elementos construtivos.

Na verdade, num primeiro estágio, ao telhado de duas águas primitivo se haviam juntado as testeiras recortadas e os pináculos torneados das construções inglesas medievais. Mais tarde, não seria incomum encontrarem-se até peças em forma de palmeta, de madeira ou de outro material, a ocupar, nas coberturas de chalé, o mesmo lugar dos acrotérios nos telhados dos antigos templos gregos. Ao mesmo tempo, as empenas triangulares resultantes das duas águas do telhado, começaram a ser tratadas como frontões clássicos, com enrolamentos fitomórficos decorativos de estuque aplicados à superfície das paredes, e perfurados por óculos de formato circular que, na maioria das vezes, funcionavam como ventiladores dos desvãos entre o teto e o telhado. Não demoraria muito e janelas apontadas, de sabor medieval, ou bay windows viriam freqüentar também essa modalidade arquitetônica, que se mostrou tão maleável aos desígnios do Ecletismo.

Não é de estranhar que um tipo de telhado específico tenha alcançado tamanha popularidade e um simbolismo tão intenso. Afinal, durante o período do Romantismo, no âmbito das edificações domésticas, por vezes, teóricos de Arquitetura atribuíam a vocabulários ornamentais de origem historicista - e até mesmo a simples elementos construtivos - uma significação simbólica muito precisa $^{16}$.

John Ruskin, por exemplo - em sua conferência sobre o Domestic Revival (Edinburgo, 1853), na qual afirmava os valores dos edifícios vernáculos e do cottage -, asseverava que era a forma do telhado o que o distinguia das construções domésticas neoclássicas, que tanto desprezava, por tal forma ser não só pitoresca por si mesma, mas por exprimir a profunda necessidade humana de um abrigo. O cottage era essencialmente um telhado. Sua alma - sua essência e significado - reduzia-se ao teto; era nisso que consistia o abrigo, era nisso que se diferenciava o cottage de uma simples fenda na rocha ou de um esconderijo entre as árvores. Era na espessa e impenetrável cobertura de palha do cottage que se concentravam o seu âmago e hospitalidade. E Ruskin convidava os ouvintes a reparar na diferença existente entre as expressões "sob o meu teto" e "entre paredes"17.

Podemos supor que os valores conferidos por Ruskin a um rústico telhado de cottage eram atribuídos por muitos de seus contemporâneos a um rendilhado telhado de chalé. Ou, antes, conseguiam até enxergar mais, pois, enquanto o telhado de colmo do cottage inglês ficou para sempre associado à noção de boa acolhida no âmbito do mundo rural anglo-saxão, o chalé transfigurado - alegre e garrido - chegou a ser visto como elemento arquitetônico cosmopolita, digno de figurar nas construções ligeiras destinadas à diversão e entretenimento, em todo o mundo ocidental. 
Introdução e difusão dos chalés em São Paulo ${ }^{18}$

Segundo o depoimento de João Fernando (Yan) de Almeida Prado, os mais remotos exemplares de chalés na cidade de São Paulo surgiram graças à influência dos engenheiros ingleses que então trabalhavam na construção da estrada de ferro de Santos a Jundiaí (1860-1867)19.

Não conseguimos localizar nenhum documento escrito ou iconográfico que ratificasse essa taxativa afirmação de Yan de Almeida Prado. Tudo o que sabemos é que, no acervo do Museu Paulista, há uma foto de autoria de Militão Augusto de Azevedo, datada aproximadamente de 1867, que talvez possa ser tomada como indício dessa hipótese. A imagem nos mostra a pequena Estação de São Bernardo como uma modesta construção coberta por um telhado de duas águas, cujas empenas laterais eram ornadas com tábuas testeiras e pináculos no ângulo superior, elementos decorativos típicos das construções inglesas medievalizantes, que se haviam incorporado na composição dos chalés oitocentistas (Figura 3).

É possível que tenham sido mesmo os ingleses os primeiros a introduzir esse gênero de construção em São Paulo, em exemplares singelos de arquitetura

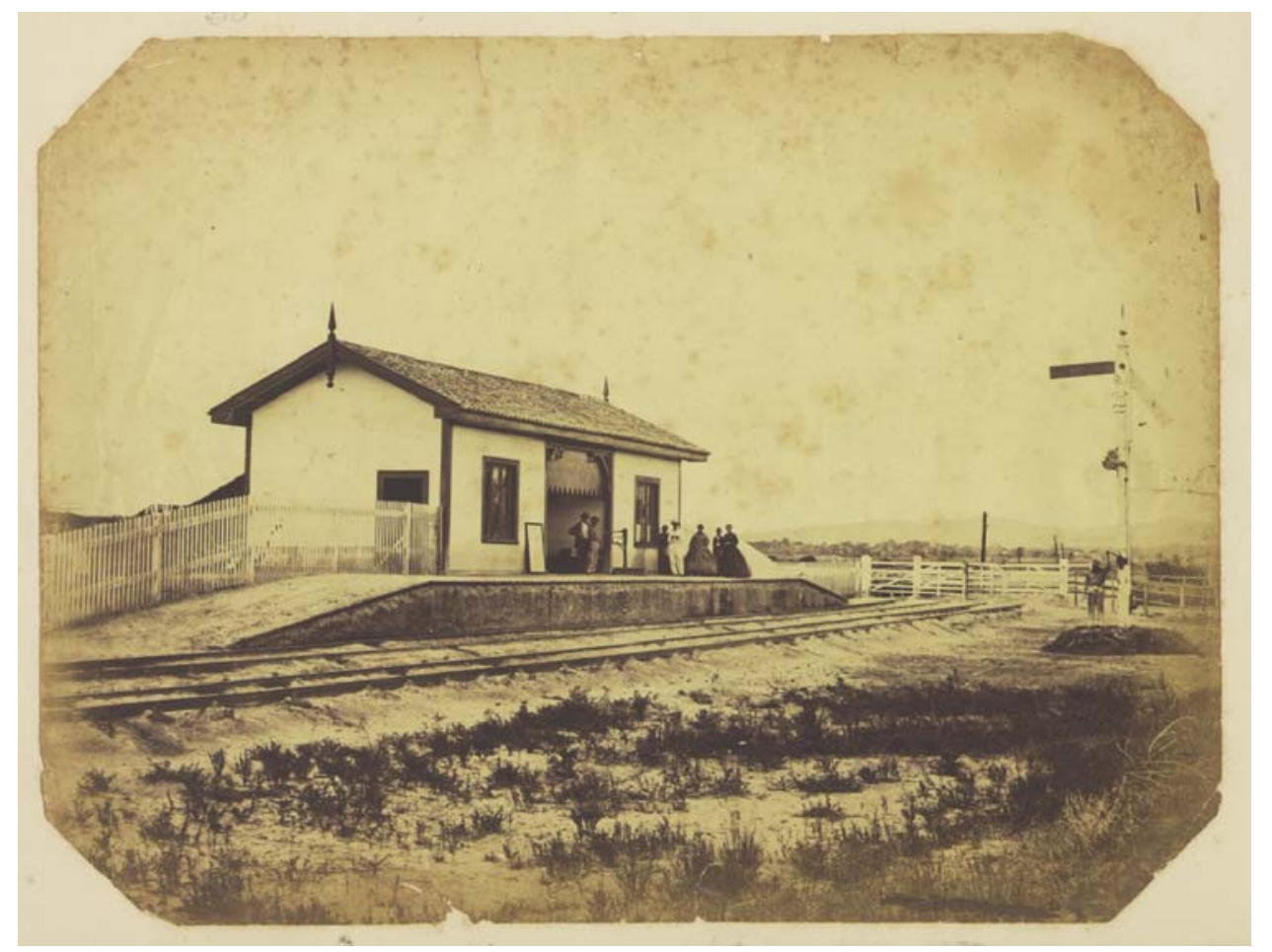

Figura 3 - Como podemos observar, a estação de passageiros de São Bernardo não passava de um edifício modesto, coberto por telhado de duas águas, com testeiras escondendo as pontas dos caibros, e ornado com pináculos, elementos decorativos que se haviam tornado distintivos dos chalés. Na parte superior da entrada, viam-se também peças de madeira entalhadas, detalhes decorativos que reforçavam o aspecto pitoresco da construção. Militão Augusto de Azevedo. Estação de passageiros de São Bernardo, c. 1867. Fotografia. Acervo do Museu Paulista da USP, São Paulo.
18. Aqui nos concentramos na investigação do chalé paulistano. Para termos uma idéia geral de como esse tipo de construção foi introduzido no país, é necessário recorrer a estudos referentes à arquitetura oitocentista do Recife, de Salvador, do Rio de Janeiro, de Petrópolis e Poços de Caldas, por exemplo, em que poderemos colher uma ou outra informação preciosa, porém, esparsa (ignoramos a existência de estudos monográficos, como o ora publicado, referentes aos chalés em outras partes do Brasil). Por constituírem os grandes centros urbanos do Brasil Império ou os lugares de vilegiatura da moda de então, nessas cidades os chalés certamente apareceram alguns anos mais cedo do que em São Paulo.

19. PRADO, J. F. de Almeida (Yan de Almeida).S. Paulo antigo e sua arquitetura. Illustração brasileira, Rio de Janeiro, anno $\mathrm{X}, \mathrm{n}^{\circ} .109$. s. p., set. 1929. 
20. Cf. CARPINTEIRO francez. ferroviária influenciados pelo Pitoresco, mas certamente não foram os únicos. Na imprensa paulistana de 1861, por exemplo, surpreendemos um carpinteiro francês divulgando seus trabalhos. Bernachot era seu nome e informava, no Correio Paulistano:

\section{Carpinteiro francez}

Bernachot, carpinteiro francez, constructor no Rio de Janeiro, do theatro de S. Pedro, do Cassino, da Beneficencia portugueza, e da estação do Caminho União e Industria, na posse [sic], achando-se nesta cidade por causa da saude, encarrega-se de tomar por empreitada quaesquer construcções que sejão, como tambem faz escadas de toda a especie, como ainda não tem apparecido em S. Paulo. $\bigcirc$ annunciante tambem dá plantas e modelos para construcções.

Hotel Paulo rua de S. Bento 20

Esse profissional não deve ter-se demorado na cidade, pois o reclame acima reproduzido foi o único encontrado por nós nos periódicos paulistanos. Seu currículo, porém, era notável: além de haver trabalhado na reconstrução do incendiado Teatro de São Pedro de Alcântara, levantou uma das curiosas estações da Estrada União e Indústria, a de Posse. Tratava-se, essa última construção, de uma estação de muda labrigo localizado a distâncias regulares ao longo da estrada, onde se efetuava o revezamento de cavalgaduras e animais de tiro), de inspiração pitoresca (Figura 4), como todas as concebidas para aquela

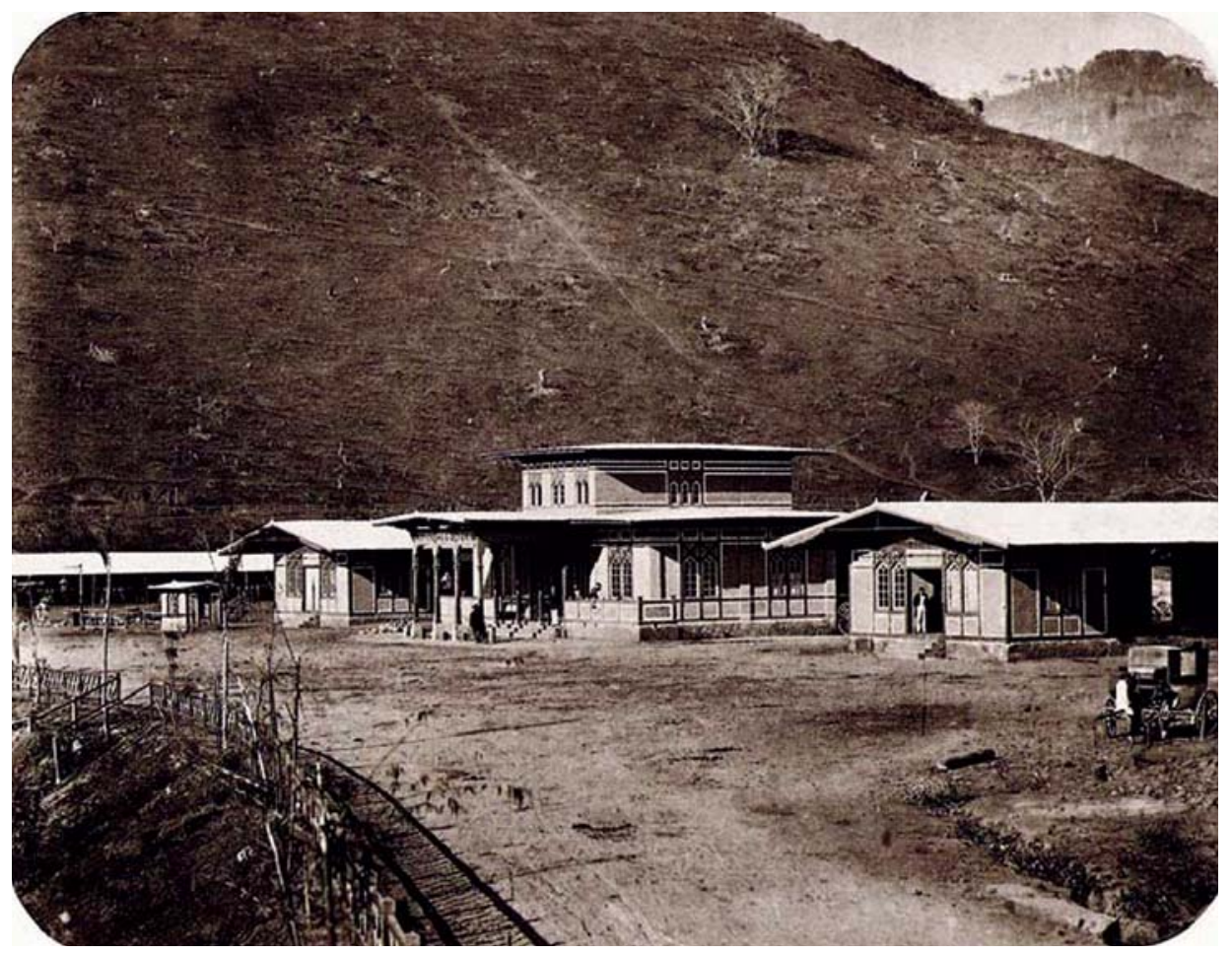

Figura 4 - Revert Henrique Klumb. Estação de muda de Paraibuna (1860), na Estrada União e Indústria, década de 1860. Fotografia. Em Vasquez (1998). 
famosa estrada de rodagem (1 856-1 861 1), que vai de Petrópolis a Juiz de Fora ${ }^{21}$. Ignoramos se obteve algum trabalho enquanto permaneceu na Capital; em caso afirmativo, poderia, quem sabe, ter sido um dos introdutores da estética do Pitoresco na arquitetura paulistana, talvez projetando e construindo algum dos primeiros chalés da cidade. Infelizmente, esse artífice, que supomos hábil e competente, não deixou vestígios, desaparecendo da mesma forma meteórica que surgiu.

Como é sabido, foi a construção da ferrovia de Santos a Jundiaí (1 860-1867) que veio dar condições para a rápida expansão da cultura cafeeira pela região oeste da Província. À medida que um número cada vez maior de sacas de café chegava ao Porto de Santos, subia, em sentido contrário, uma quantidade sempre crescente de produtos importados, entre eles artigos de construção que seriam aplicados nas novas casas paulistas ou, ao menos, has destinadas às camadas mais abastadas.

A crise inflacionária desencadeada no final da Guerra do Paraguai ocasionou a falência do Banco Mauá (1875) e foi esse desastre financeiro que motivou os membros das camadas privilegiadas a investir em bens de raiz na Capita $^{22}$. Justamente dessa fase de ampla renovação e expansão imobiliária paulistana data a proliferação dos chalés pelos arrabaldes da cidade. Indicativo disso é o anúncio que a Olaria do Bom Retiro fazia publicar no Correio Paulistano em 1878. O estabelecimento, de propriedade do advogado, empresário e banqueiro João Ribeiro da Silva, comunicava encarregar-se de construir casas e chalés nos terrenos que vendia em Santa Ifigênia. Responsável pelas obras e plantas que fossem encomendadas achava-se o arquiteto francês Charles Peyronton, formado na Academia de Bordéus e, afirmava-se, "vantajosamente conhecido na America do Sul, pelas importantes obras que tem feito" 23 .

Pela leitura dos anúncios em jornais, podemos acompanhar a maneira pela qual o consumidor provido de recursos pouco acima da média ia ficando cada vez mais exigente em relação às residências que estavam sendo colocadas no mercado imobiliário paulistano. Até a década de 1860, nos avisos de venda ou locação de casas, o imóvel nunca era descrito a não ser sumariamente. Quase sempre o número de janelas voltadas para a rua bastava para dar uma idéia do padrão da moradia, sendo comum louvar-se a qualidade dos materiais de construção utilizados, sobretudo na fase correspondente à transição de sistema construtivo na cidade de São Paulo (1850-1870). Com freqüência, só se mencionava serem casas térreas ou de sobrado para pequenas ou grandes famílias. Mais tarde, esporadicamente, se referiam ao fato de serem as casas assobradadas (isto é, com piso único sobre porão) e providas de compartimentos espaçosos, independentes, arejados e iluminados por janelas.

Com o avanço das noções de higiene e conforto, e com o rápido suceder de empresas de serviços públicos postas em atividade na Capital a partir dos anos 1870, começam a surgir longas e minuciosas descrições, destacando todas as comodidades que estavam ao alcance do feliz comprador ou locador do imóvel anunciado: água da Cantareira, esgotos, luz a gás, fogão econômico, latrinas no sistema inglês, banheiros azulejados ou cimentados,
21. Ver ilustração da estação de Paraibuna em Pedro C. S Telles (1984,p. 173-174). Das 12 antigas estações, hoje só se conserva, parcialmente, essa de Paraibuna (1860), no município de Comendador Levy Gasparian, tombada pelo Instituto do Patrimônio Histórico Nacional e onde está instalado o Museu Ferroviário. Uma construção de estilo pitoresco, de dois pavimentos, cobertura de chapas galvanizadas e estrutura de madeira trabalhada. $O$ pórtico de entrada apresenta cobertura de duas águas com pouquíssima inclinação, como os telhados dos chalés. O edifício da estação era ladeado por dois outros, igualmente cobertos por telhados de duas águas, com empena frontal e largos beirais. A esse respeito, ver ainda, Pedro Karp Vasquez (1998, passim). Nessa obra acha-se reproduzida excelente documentação fotográfica de época, realizada, por volta de 1861, pelo fotógrafo alemão Revert Henrique Klumb (183?-c.1886), referente às várias estações de muda da Estrada União e Indústria. Entre elas, vê-se não só a estação da Posse como as demais estações, algumas das quais concebidas à maneira de chalé

22. Ver Antônio Egídio Martins (1973, p. 238).

23. Cf.ANNUNCIOS 
24.Ver Eudes Campos (1997, cap.4, p. 318-341).

25. Ver CARPINTARIA a vapor.

26.Ver FABRICA de SantoAntonio.

27.Ver ALMANACH administrativo... ([1887?], p. 17)

28. Ver CRÊTE de faîtage em terre cuite. banheiras de mármore com água quente e fria, banho de chuva em área cimentada, cozinha com lavatório de louça, grande jardim com aposentos para criado, com boas e raras flores, gradil e portão de ferro, repuxos, cascatas, e várias benfeitorias no quintal: horta, pomar, galinheiro, cocheiras, poço com bomba, tanque para lavar roupa; e, ainda, bondes à porta ou a poucos minutos de distância. Dessas casas erguidas nos subúrbios, às vezes se desfrutavam belas vistas; com sorte, o local onde se situavam era, além de aprazível, muito saudável pela "proximidade do gazometro" - sendo esta última observação motivada pela crença que se tinha de que as emanações provenientes da produção de gás de iluminação eram benéficas às pessoas com problemas pulmonares. Nos anos 1880, freqüentemente todos esses itens de bem-estar estavam reunidos sob o mesmo teto, em geral um teto rendilhado de chalé suburbano, num misto de modernidade e fantasia.

Após a inauguração da ferrovia inglesa, a renovação das técnicas construtivas que havia atingido a Capital avançou com rapidez. E isso resultou no fato de, provavelmente, desde os primeiros chalés, virem sendo neles empregados os novos materiais de construção: tijolos, abundantemente produzidos na Capital a partir dos anos de 1860; madeiras importadas (pinhos estrangeiros), aparelhadas ou perfiladas nas serrarias a vapor recém-abertas na cidade; elementos de ferro fundido (vigas, colunas, rosetas de respiradouros de porão, etc.), tanto introduzidos pelo porto de Santos, quanto fabricados nas fundições locais (notemos que uma fundição criada por antigos funcionários estrangeiros da Fábrica do Ipanema estava instalada nas proximidades da Estação da Luz desde 1868), além de telhas planas importadas de Marselha, já imitadas em 1885 pelo coronel Antônio Proost Rodovalho em sua Fazenda das Caieiras, nos Perus, próximo do Juqueri ${ }^{24}$.

No Correio Paulistano de 3 de abril de $1881^{25}$ encontramos um reclame da carpintaria a vapor denominada Fábrica de Santo Antônio, de propriedade de D.J.C. Silva. A serraria anunciava ter colocado à disposição de seus fregueses um desenhista francês, especialmente contratado para criar ornatos de chalés. Já em 1877, quando inaugurado por Braga e Cia., no Bexiga, o mesmo estabelecimento afirmava, na imprensa diária, ter máquinas para fazer recortes finos e vazados, máquinas que naturalmente eram usadas na execução dos enfeites rendilhados apropriados para esse tipo de construção ${ }^{26}$.

Aliás, deve-se notar que os elementos decorativos mais típicos dos chalés oitocentistas, os lambrequins, não eram feitos apenas de madeira recortada. Sabemos ter havido lambrequins de zinco, estampados e em relevo, e chegamos a encontrar, em anúncios, alusão a surpreendentes e curiosos lambrequins de cerâmica ${ }^{27}$. É possível, contudo, que nesse último caso não se tratasse propriamente de testeiras rendadas, mas de frágeis peças ornamentais, aplicadas uma junto da outra, ao longo das cumeeiras, formando vistosas cristas de terracota (crêtes de faîtage). Substituindo as costumeiras peças de ferragem decorativa, essas cristas peculiares podem ser vistas ainda hoje em telhados de construções interioranas francesas ${ }^{28}$. 
Os chalés não eram construídos apenas com material vindo de fora e com auxílio de trabalho mecânico; de fato, muitos, feitos de madeira, foram inteiramente fabricados no Exterior e despachados desmontados para cá. Nascido em Santos, e um dos primeiros engenheiros paulistas a se formar nos EUA, Fernando de Albuquerque parece ter sido, durante algum tempo, o representante em São Paulo de um fabricante norte-americano. Em 1878, anunciava numa das folhas publicadas na cidade:

Construcção de chalets: o engenheiro Fernando de Albuquerque possue uma variada collecção de plantas para construcção de chalets americanos 29 .

A Serraria Bela Vista, por sua vez, situada nos Campos Elísios e de propriedade de um importante personagem da época, Elias Pacheco Chaves, mantinha na superintendência do negócio o engenheiro-arquiteto alemão Mateus Häussler. Esse profissional se encarregava de fazer plantas e orçamentos para construções de qualquer gênero, assim como da construção de edifícios, por empreitada ou administração. Decerto, projetava, de preferência, chalés, pois era nesse tipo de construção que poderiam ser abundantemente aproveitadas as madeiras comercializadas na serraria ${ }^{30}$. Entre os chalés que presumidamente projetou, contava-se, decerto, aquele em que habitou o major Diogo de Barros, proprietário de uma construção desse tipo ao lado de sua fábrica de tecidos da rua Florêncio de Abreu, como veremos adiante.

Construções românticas e nostálgicas por excelência, legítimas herdeiras da estética do Pitoresco, os chalés erguidos nos subúrbios paulistanos só seriam considerados perfeitos se tivessem uma ambientação paisagística adequada. Era justamente isso que sucedia com os vistos por Koseritz na Corte em 1883. Estes últimos mostravam-se muito agradáveis pois, à maneira eclética, conciliavam típicas construções de regiões nevadas com exuberantes espécimes característicos da flora das regiões quentes:

são cercados de lindos jardins, cujas flores tropicais, lindas palmeiras e plantas ornamentais se misturam com grutas cintilantes, regatos com pontes, cascatas e repuxos num conjunto encantador ${ }^{31}$.

Ao criar um paisagismo apropriado aos chalés, os jardineiros de então mantinham viva a tradição dos velhos jardins pitorescos, com canteiros irregulares, tanquinhos, repuxos, grutas de embrechados e pontilhões, agora ladeados de guarda-corpos feitos de troncos falsos de cimento. Não era portanto por acaso que profissionais se anunciavam nos jornais prontos para executar esse tipo de ornamentação de gosto ingênuo, mas legitimamente coerente com a estética pitoresca surgida nos Setecentos:

Serafim Corso Mestre de Obras - acceita obras por empreitada ou administração, encarregase de embellezamento de jardins, grutas, cascatas, etc. Acceita trabalhos para fôra. S. Paulo - 34, Rua do Imperador, 34. S. Paulo ${ }^{32}$.
29. Cf.AVISOS - Construcção de chalets.

30. ALMANACH administrativo... (1886, p. 31).

31. Cf. Carl von Koseritz (1980, p. 75).

32. ALMANACH administrativo... ([188-], p. 55). 
33. São Paulo (Estado) (Correspondência, Ordem 5195).

34.Ver EMPRESA Paulista de Eletricidade

35. Ver VENDE-SE.

36. Ver TELHAS francezas

37. Cf. Firmo de A. Diniz (Junius). (1978, p. 35)

38. SÃO PAULO (Cidade) $(L i$ vros de lançamento, v. 0376 , folha $149 \mathrm{v}$ )
Foi esse mesmo Serafim Corso quem desenvolveu o projeto da fonte do jardim do Palácio do Governo, no largo de Palácio (hoje pátio do Colégio), em 1886, a partir de um croquis fornecido por um engenheiro provincial - fonte em que se aliavam a pomposa linguagem da arquitetura neo-renascentista do Segundo Império francês e os tronquinhos tortuosos e as pedras falsas feitos de cimento armado ${ }^{33}$. Foi esse mesmo profissional italiano quem executou, por essa mesma época, a grande gruta do Jardim da Luz, até hoje existente.

Se, por um lado, é fato que os chalés se reportavam a uma idealizada vida campestre, natural e simples, por outro, parece claro o envolvimento desse tipo de habitação com a modernidade. Isso se traduzia, por exemplo, na intensa busca de conforto por parte dos moradores de chalés. A novidade representada pela aparência formal da construção parecia estimular o proprietário a sair em busca de outras inovações no campo da técnica. Muito provavelmente não é mera coincidência o fato de Abílio A. S. Marques (português, morador num chalé da rua Barão de ltapetininga, no morro do Chá) ter iluminado sua casa com eletricidade desde 1881 . Entusiasmo que o levou a inaugurar os serviços da primeira empresa de iluminação elétrica da cidade em $1888^{34}$. Outro destacado personagem contemporâneo, o major Diogo Antônio de Barros, também se mostrou grande admirador da luz elétrica por incandescência. Empregou-a em seu chalé da rua Florêncio de Abreu, nas proximidades da fábrica de tecidos de algodão de sua propriedade, experiência que, infelizmente, parece não ter durado.

A notícia mais recuada que conseguimos localizar sobre chalé residencial erguido na Capital foi encontrada num anúncio do Correio Paulistano de 22 de setembro de 1877, o que o insere certamente na vaga construtiva que se seguiu à quebra do Banco Mauá. Segundo esse anúncio, Manuel Ferreira Leal, antigo mestre-de-obras da ferrovia inglesa e empreiteiro lusitano, punha à venda um pequeno exemplar, do qual era dono, situado no largo da Glória, chalé esse provavelmente por ele projetado e construído ${ }^{35}$. Significativamente, essa construção era contemporânea dos primeiros anúncios de telhas de Marselha que se faziam na imprensa diária da cidade ${ }^{36}$, pois, como se sabe, as duas águas lambrequinadas eram em geral cobertas com esse tipo de telhas planas importadas. Já bastante numerosos, os chalés foram surpreendidos por Junius nos arrabaldes da cidade por volta de 1882: no Chá, nos Campos Elísios e na estrada do Vergueiro ${ }^{37}$.

Sem muito custo, conseguimos identificar algumas dessas moradias destinadas aos estratos médios superiores. Numa ilustração alegórica da inauguração do Viaduto do Chá em 1892, por exemplo, surpreendemos o chalé onde habitava de Abílio A. S. Marques, no Chá, no local onde hoje se vê o Edifício Alexandre Mackenzie, atualmente ocupado pelo Shopping Light (Figuras 5 e 6). Construída a partir de 187938, a casa era dotada de dois pavimentos, com fachadas simétricas e envasaduras com arcos apontados, influenciados pelo medievalismo então em voga. Erguia-se no meio do lote, rodeada de um pequeno jardim à inglesa, complementação ideal para essas extravagantes construções. A partir de 1886, seu endereço nos almanaques aparece como 


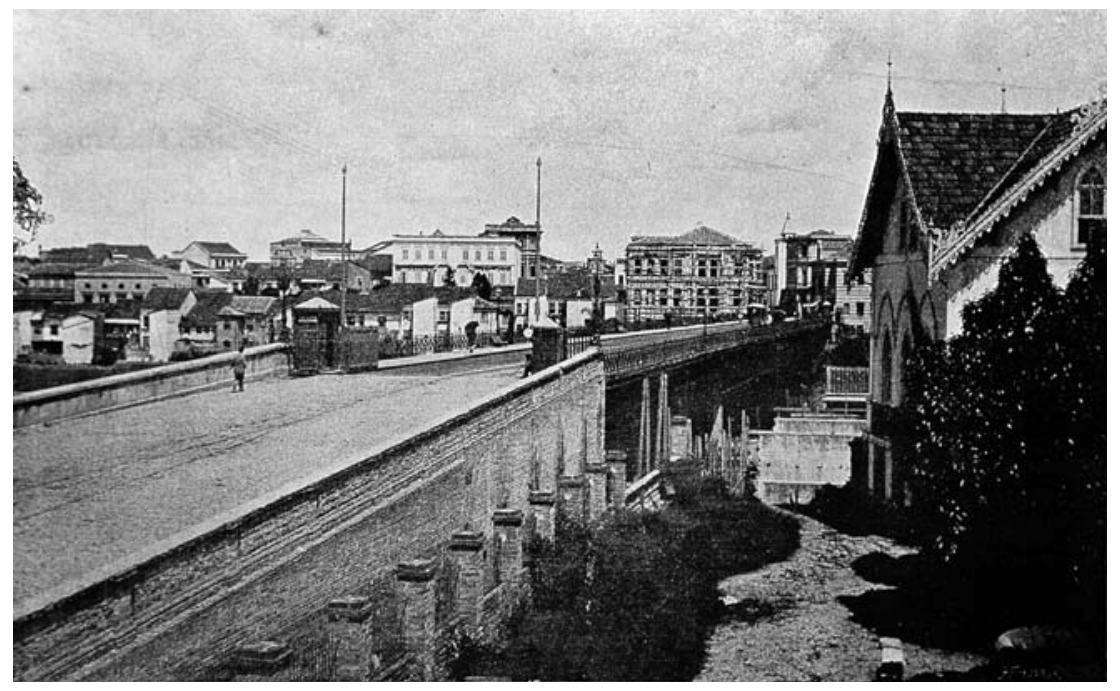

Figura 5 - À direita da imagem, vê-se o chalé em que habitava Abílio A. S. Marques, no local onde se ergue hoje o Edifício Alexandre Mackenzie, atualmente ocupado pelo Shopping Light. Axel Frick. Vista do Viaduto do Chá (c. 1895). Fotografia. Em Gustavo Koenigswald (1895). Acervo Biblioteca Mário de Andrade, São Paulo. Reprodução José Rosael.

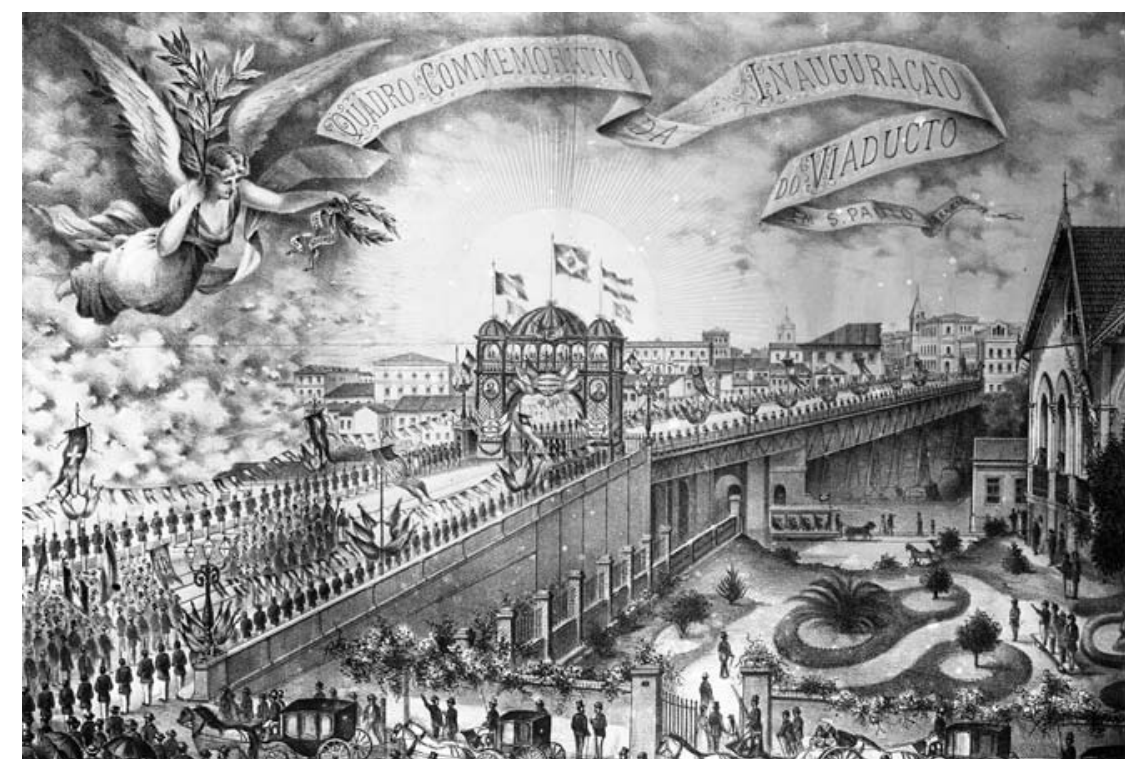

Figura 6 - Nessa gravura, observa-se à direita o mesmo chalé visto na foto anterior, com jardinzinho de feições românticas, com seus caminhos sinuosos e aparentemente ornado com um belo exemplar de cicadácea. No confronto com a Figura 5, verificase que esse paisagismo não passava de uma idealização artística, mas mesmo assim muito eloqüente na medida em que revela quanto a exótica vegetação de origem tropical e a estética pitoresca eram bem-vindas em ambientações de chalés. Jules Martin (atribuição). Ilustração alegórica comemorativa da inauguração do Viaduto do Chá, 1892. Fotografia. Acervo da Divisão de Iconografia e Museus, DPH, São Paulo. 
39. Ver ALMANACH administrativo... (1884, p. 225).

40.Ver SÃO PAULO (Cidade) (Mappa topographico, folha 51/12).

41. Cf. Ricardo Severo (1917, p. 415). rua Barão de Itapetininga, n. 1, e, como dissemos antes, chamava a atenção por ser iluminada à luz elétrica, desde 1881 segundo consta.

Outro chalé notável, geralmente visto à distância em antigas imagens do bairro da Bela Vista, era a residência do engenheiro Fernando de Albuquerque, à qual se alude no almanaque paulista editado em $1884^{39}$. Apresentava curiosa planta cruciforme, segundo o Mapa SARA Brasil|40 (Figura 7), o que interpretamos ser um ingênuo expediente para conferir alguma movimentação à planivolumetria originalmente muito simples do chalé, característica que levou Ricardo Severo, muitos anos depois, a defini-lo pejorativamente como construção "em forma de cazota de cachorro" 41 . Igual a tantos outros, esse chalé do Bexiga estava provido de varanda e avantajados lambrequins filigranados (Figuras 8-13).

Seu proprietário, graduado na América do Norte, dava a conhecer nos jornais que dispunha de plantas de chalés americanos para atender os

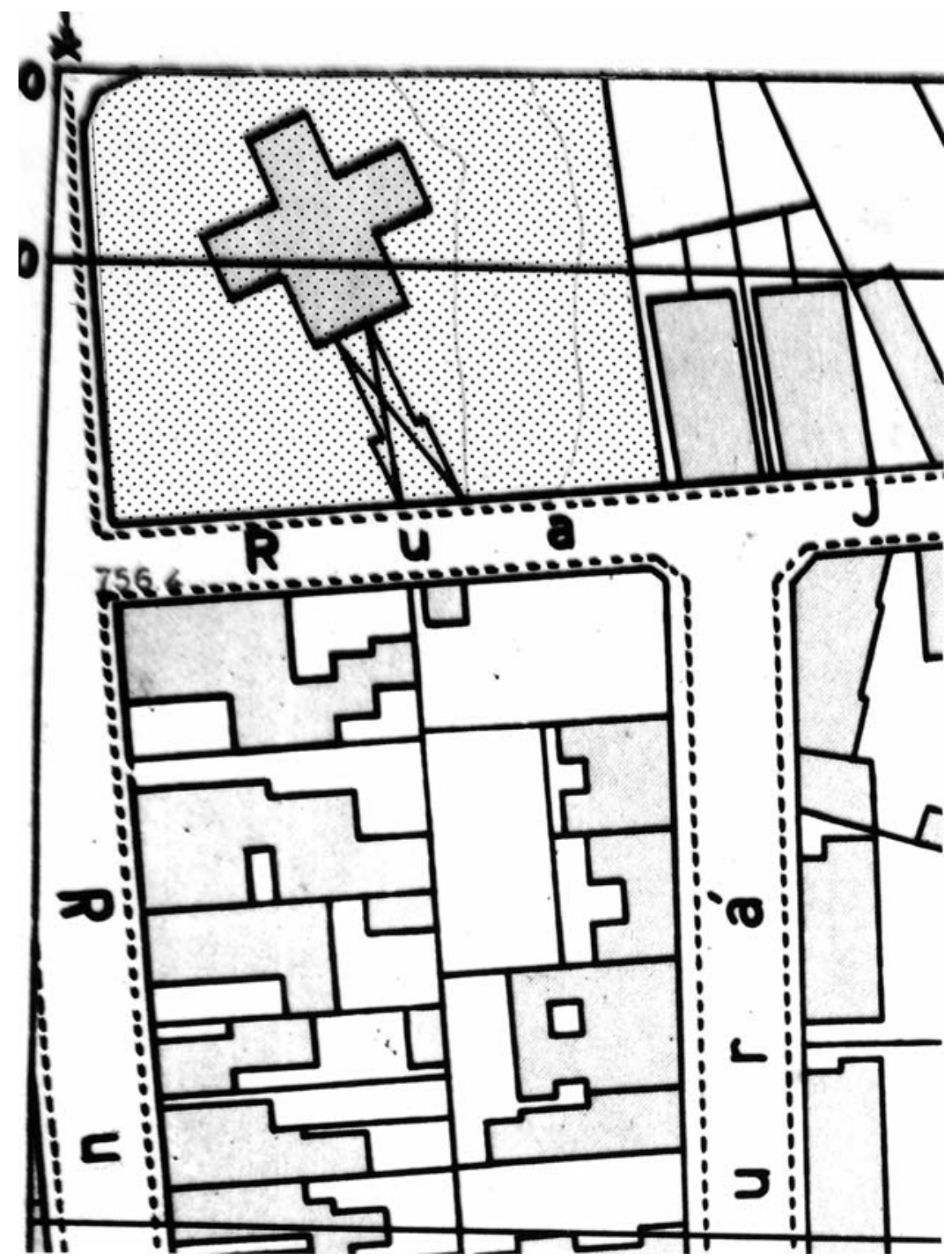

Figura 7 - Pormenor do mapa SARA Brasil (1930), mostrando a projeção horizontal do antigo chalé de Fernando de Albuquerque. Vôo aerofotogramétrico de 1929. Acervo do Arquivo Histórico Municipal, São Paulo. 


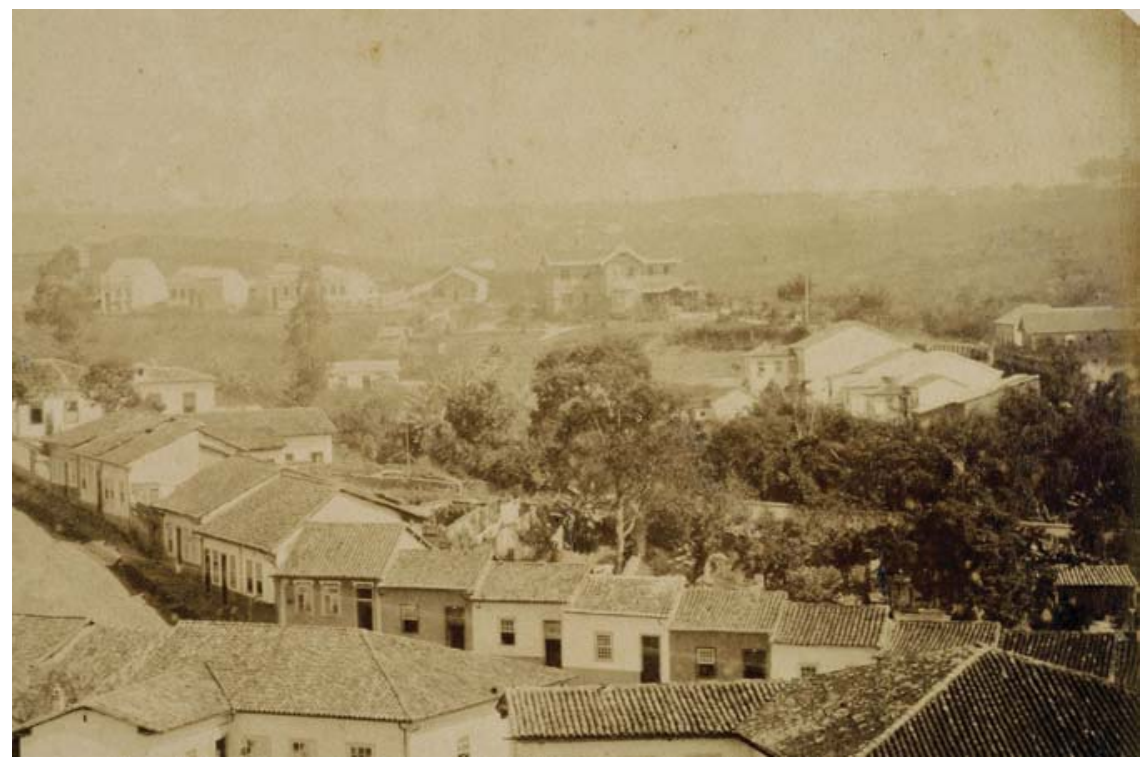

Figura 8 - Ao fundo, chalé que pertenceu ao engenheiro Fernando de Albuquerque, na Bela Vista. É flagrante o contraste que esse tipo de construção provocava na paisagem urbana paulistana de então, ainda completamente dominada pelas casas de taipa, vistas em primeiro plano. Militão Augusto de Azevedo. Vista do bairro da Bela Vista (detalhe). 1887. Fotografia em Album Comparativo de São Paulo. Acervo do Museu Paulista da USP, São Paulo. Reprodução de José Rosael.

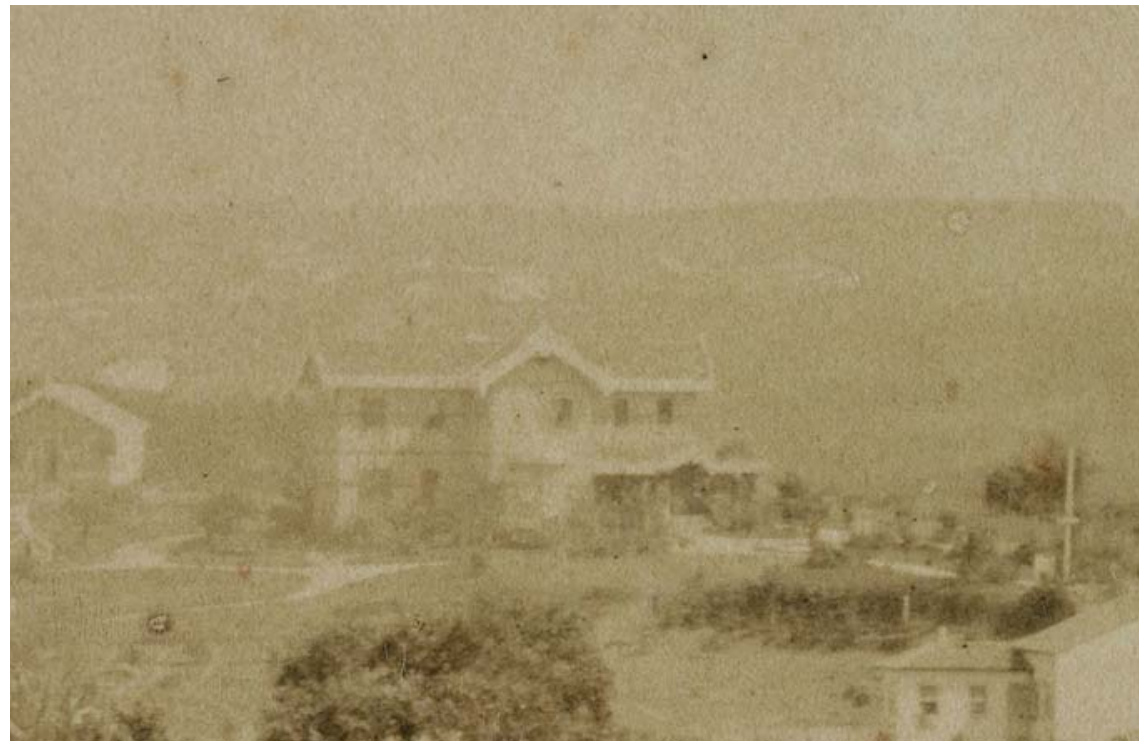

Figura 9 - Aqui podemos distinguir melhor o tipo de ajardinamento que rodeava o chalé de Fernando de Albuquerque: vasta área ajardinada, com maciços arbustivos distribuídos ao acaso e gramados cortados por caminhos de traçado sinuoso. Detalhe da Figura 9. Reprodução de José Rosael. 


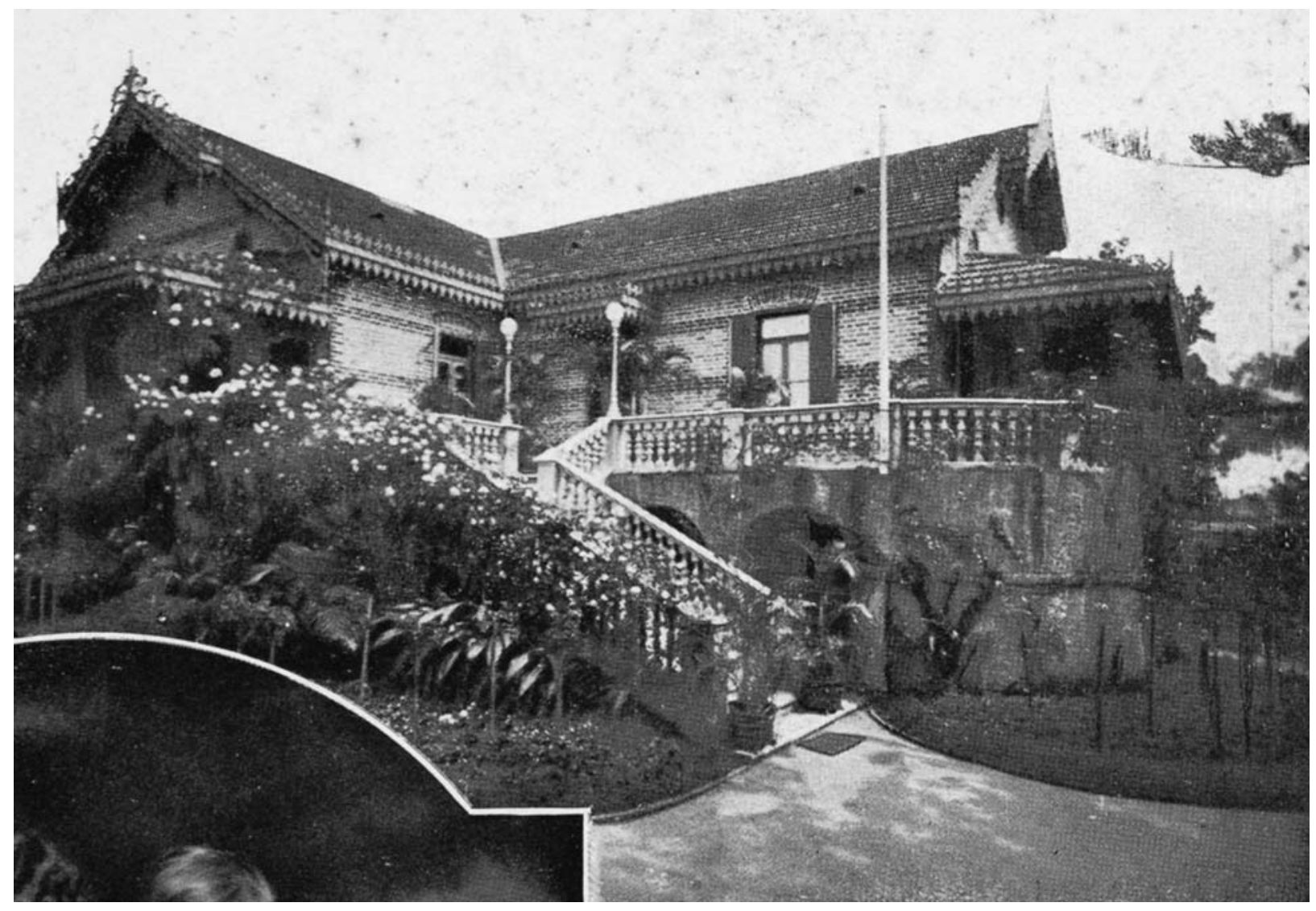

Figuras 10 a 13 - Vemos aqui o mesmo chalé da imagem anterior, em publicação do início do século XX. Notamos que naquela altura, ocorrera ampla reforma na antiga residência de Fernando de Albuquerque, cujo endereço era então Rua Santo Antônio, n. 83. O andar térreo fora transformado em volumoso embasamento com terraço balaustrado. O telhado tivera a largura dos beirais diminuída, ficando, porém, intacta a parte superior das empenas, o que produziu ressaltos nas testeiras lambrequinadas. Também digno de nota é o ajardinamento profuso que passou a envolver a construção, com sua densa vegetação florida recobrindo treliças e caramanchões. Residência do Sr. William E. Lee. Fotografia. Em Societé de Publicité Sud-Americaine Monte Domeca et Cie. (1918). Acervo do Museu Paulista da USP, São Paulo. Reprodução José Rosael. 

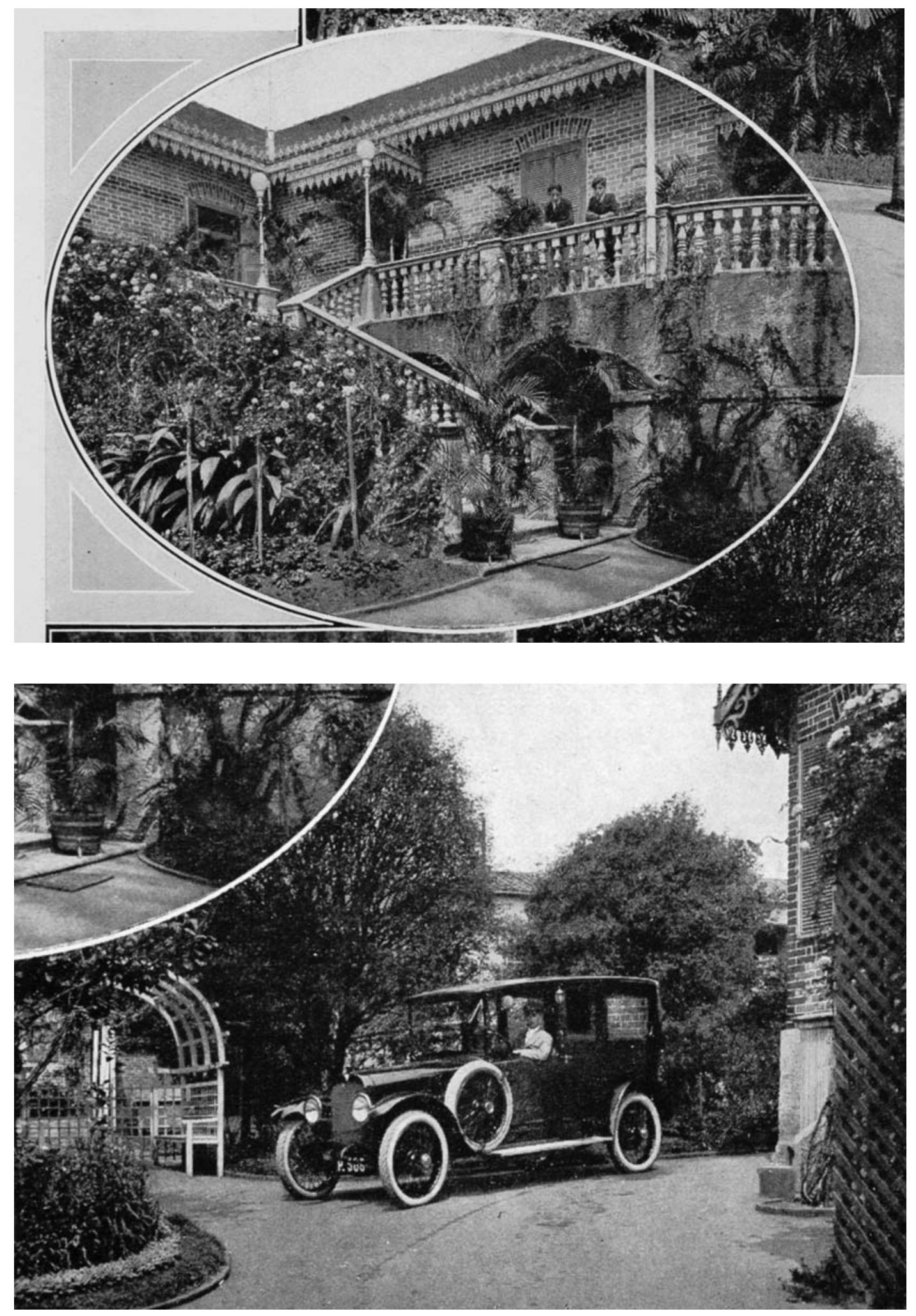

Annals of Museu Paulista.v. 16. n.1. Jan.-June 2008. 


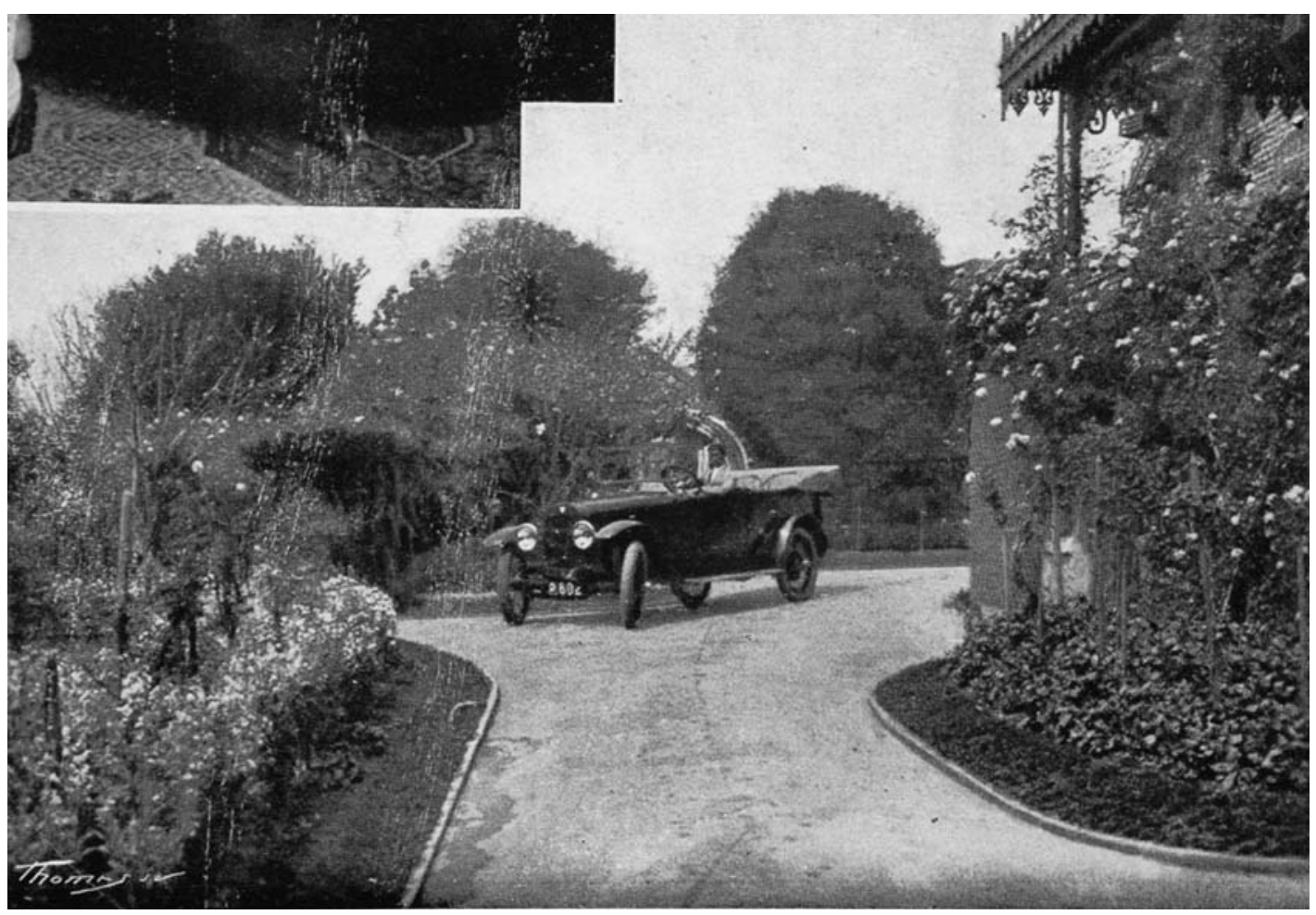

42.Ver Eudes Campos (1997, cap. 2, nota 208).

43. Ver SÃO PAULO (Cidade) (1954, planta n.9).

44.Ver SÃO PAULO (Cidade) (Obras particulares, v. 021, folha 201).Ver também Eudes Campos (2005).

45.Ver SÃO PAULO (Cidade) (Livros de lançamento, $\mathrm{v}$. 0376 , folha $175 v$ ). paulistanos que quisessem edificar, e isso nos faz supor que sua casa tivesse as partes de madeira executadas nos EUA, em pinho branco americano, e, a seguir, de lá despachadas desmontadas, a exemplo do que sucederia mais tarde com construções integralmente importadas erguidas no balneário do Guarujáa ${ }^{42}$.

Na perspectiva da rua Florêncio de Abreu em direção à Luz, de autoria de Militão de Azevedo, datada de 1887, podemos entrever, ao fundo, à direita, parte do chalé (Figura 14) onde morou outro amante do progresso técnico, o já mencionado major Diogo Antônio de Barros, que, como vimos, também fez experiências com eletricidade em sua residência. Esse chalé exibia, ao que parece, ao menos três fachadas simétricas com empenas lambrequinadas, e sua projeção horizontal, visível na planta de 1881, aproximava-se da forma de um quadrado ${ }^{43}$. Atribuímos a autoria dessa moradia ao engenheiro Mateus Häussler, já que sabemos que, pouco tempo depois, esse talentoso profissional alemão construía para Diogo de Barros na rua 25 de Março $^{44}$.

A sede da chácara do coronel Proost Rodovalho, situada no morro do Chá com entrada pela rua Formosa, edificada em 1879 pelo mestre português Manuel Ferreira Leal ${ }^{45}$, também mostrava evidentes particularidades rurais. Acompanhando formalmente a construção principal, os dois anexos que deitavam sobre aquela via, cocheiras decerto, apresentavam-se devidamente cobertos por telhados de chalé, conforme atesta foto de Militão Augusto de Azevedo tomada em 1887 (Figura 15A a 15D). 


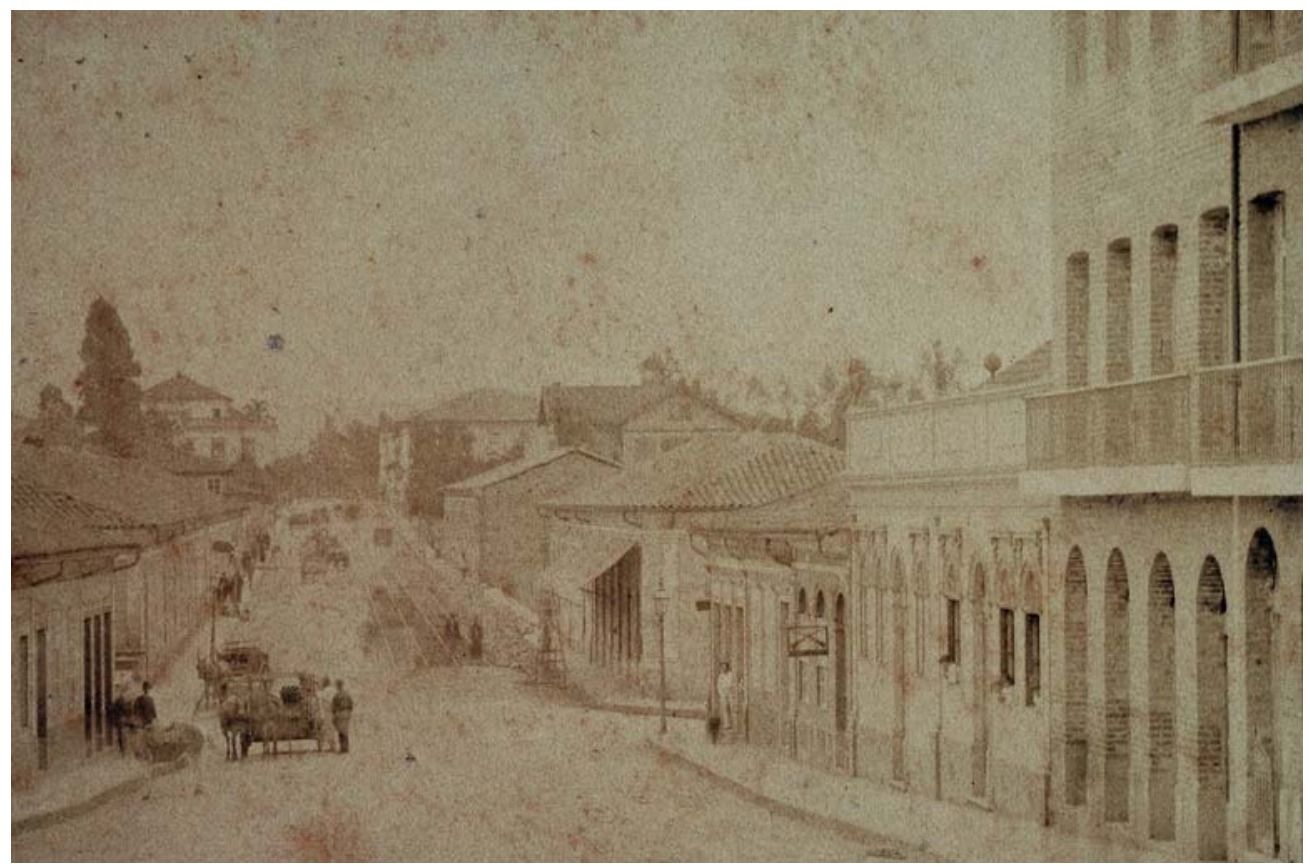

Figura 14 - No centro da imagem, destaca-se parte do chalé onde morou o major Diogo Antônio de Barros, residência erguida ao lado de sua fábrica de tecidos de algodão. Militão Augusto de Azevedo. Rua da Constituição (Florêncio de Abreu) em direção à Luz (detalhe), 1887. Fotografia em Album comparativo da cidade de São Paulo. Acervo do Museu Paulista da USP, São Paulo. Reprodução de José Rosael.

Num outro registro fotográfico referente à antiga rua Alegre (Brigadeiro Tobias), tirado por Militão nesse mesmo ano de 1887, reconhecemos um sobrado pertencente ao então conde de Três Rios (Figura 16). Localizado na esquina da rua Alegre com a via que durante algum tempo foi conhecida pelo nome de travessa do Barão de Piracicaba (atual avenida Senador Queirós), tratava-se aparentemente de uma residência de aluguel, erguida a partir de $1880^{46}$. Nesse sobrado, a linguagem formal neo-renascentista, com bossagens à moda lombarda, aliava-se com harmonia aos detalhes específicos dos chalés: empena frontal, lambrequins e demais ornatos filigranados de cobertura, e ainda, na fachada, sacada corrida de madeira, único caso em que seria lícito servir-se desse material para a fabricação de balcões, consoante o último padrão edilício paulistano do tempo do Império, datado de $1889^{47}$.

Temos conhecimento de ter existido também um outro exemplar no Brás, na rua Monsenhor Anacleto, n. 38. Na parte externa do edifício, a decoração de raiz clássica convivia bem com a cobertura de duas águas típica dos chalés (Figura 17). É possível que haja sido especialmente projetado para abrigar uma instituição de ensino, no caso, o Colégio Azevedo Marques, que se anunciava em $1887^{48}$. Excepcionalmente, essa edificação permaneceu em funcionamento até ao menos o primeiro quartel do século XX, quando
46. Idem (v. 0481, folha $175 v)$. Ver também Eudes Campos (2005, p. 36).

47.Ver Eudes Campos (1997, cap. 7, p. 721).

48. Ver ALMANACH administrativo... ([1887?], p. 3). 


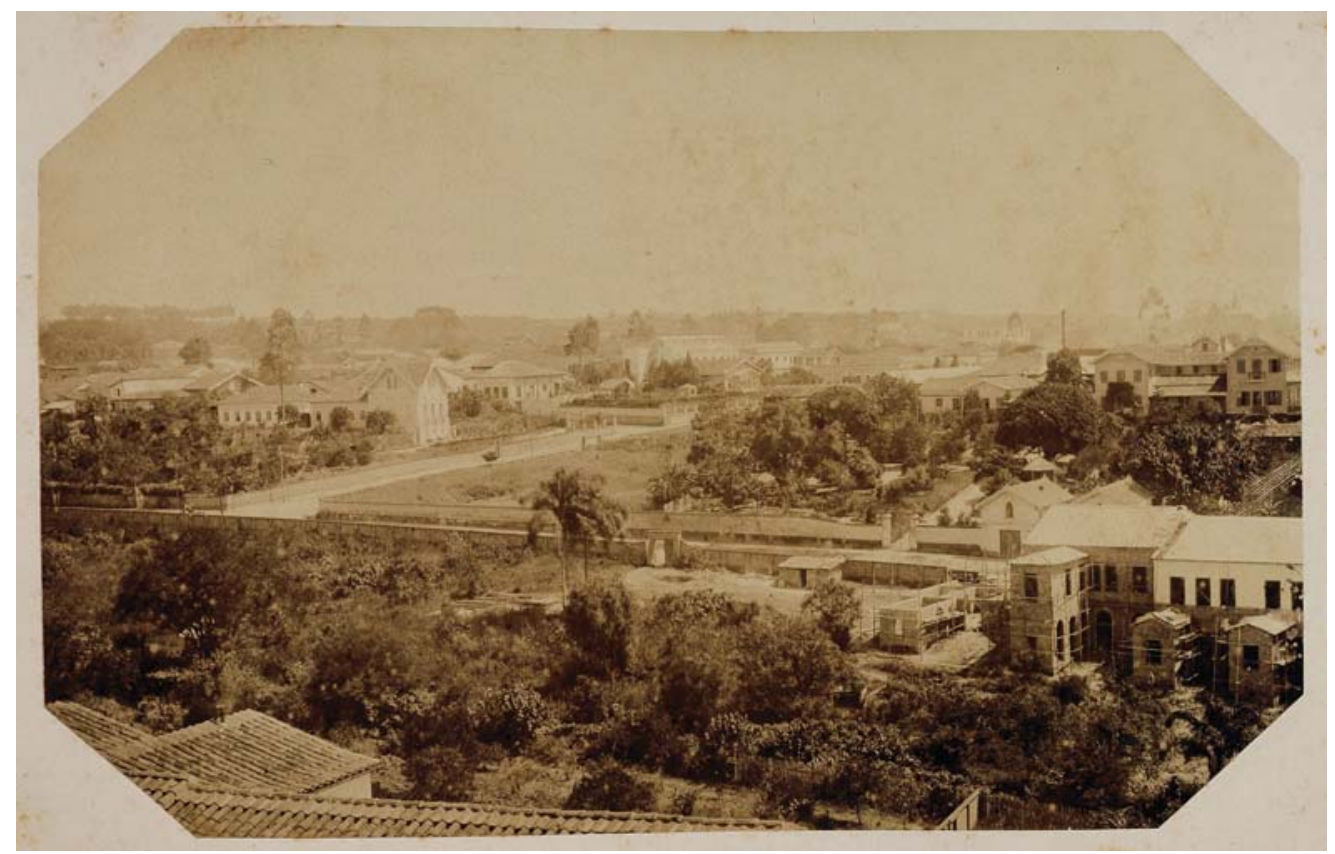

Figura 15 A - Vista do morro do Chá, tirada a partir do Grande Hotel , sito na rua São Bento. Militão Augusto de Azevedo. Morro do Chá, 1887. Fotografia em Album comparativo da cidade de São Paulo. Acervo do Museu Paulista da USP, São Paulo. Reprodução de José Rosael.

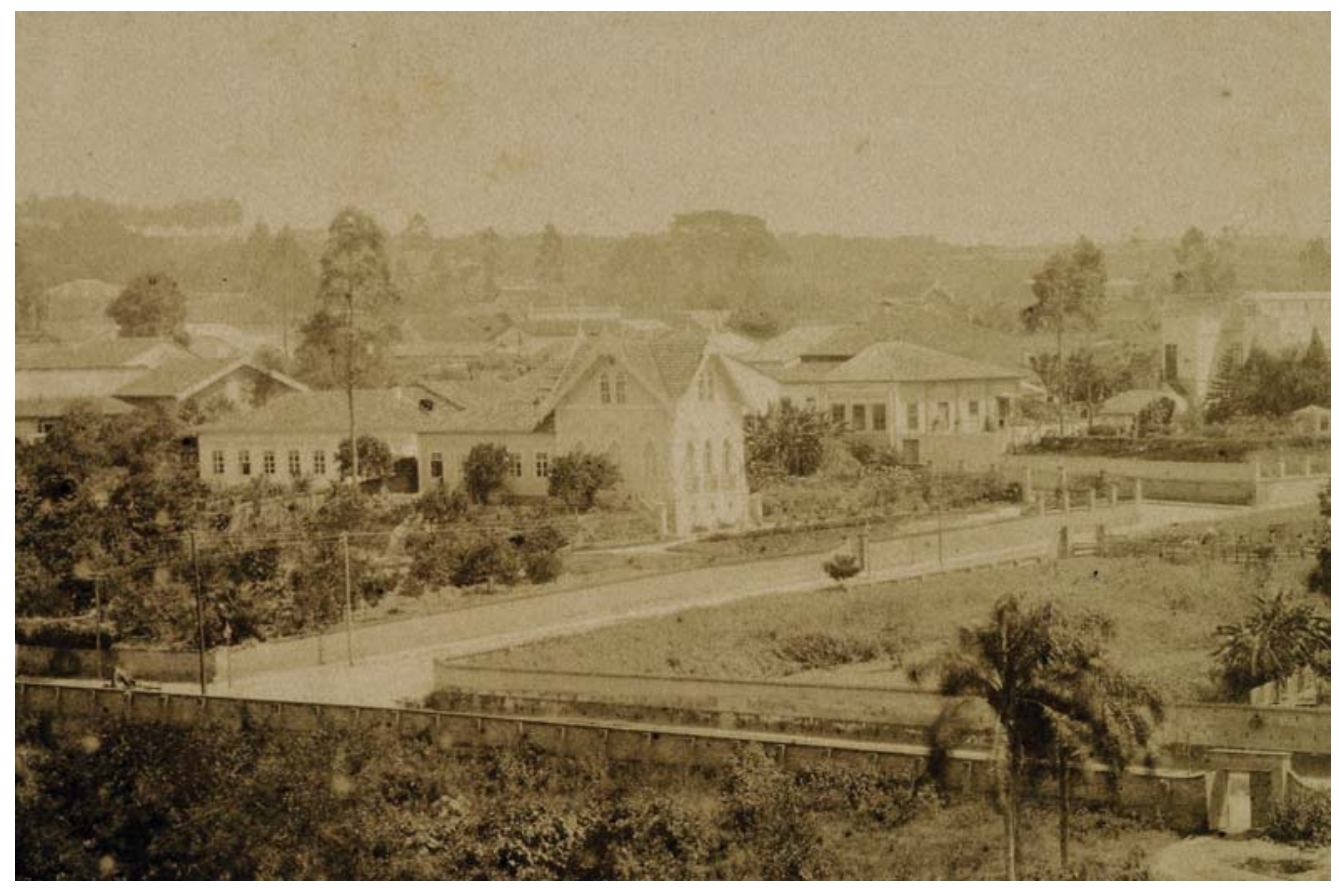

Figura 15 B - Aqui se vê a imagem do chalé onde habitava Abílio A. S. Marques. Detalhe da Figura 15A. Reprodução de José Rosael. 


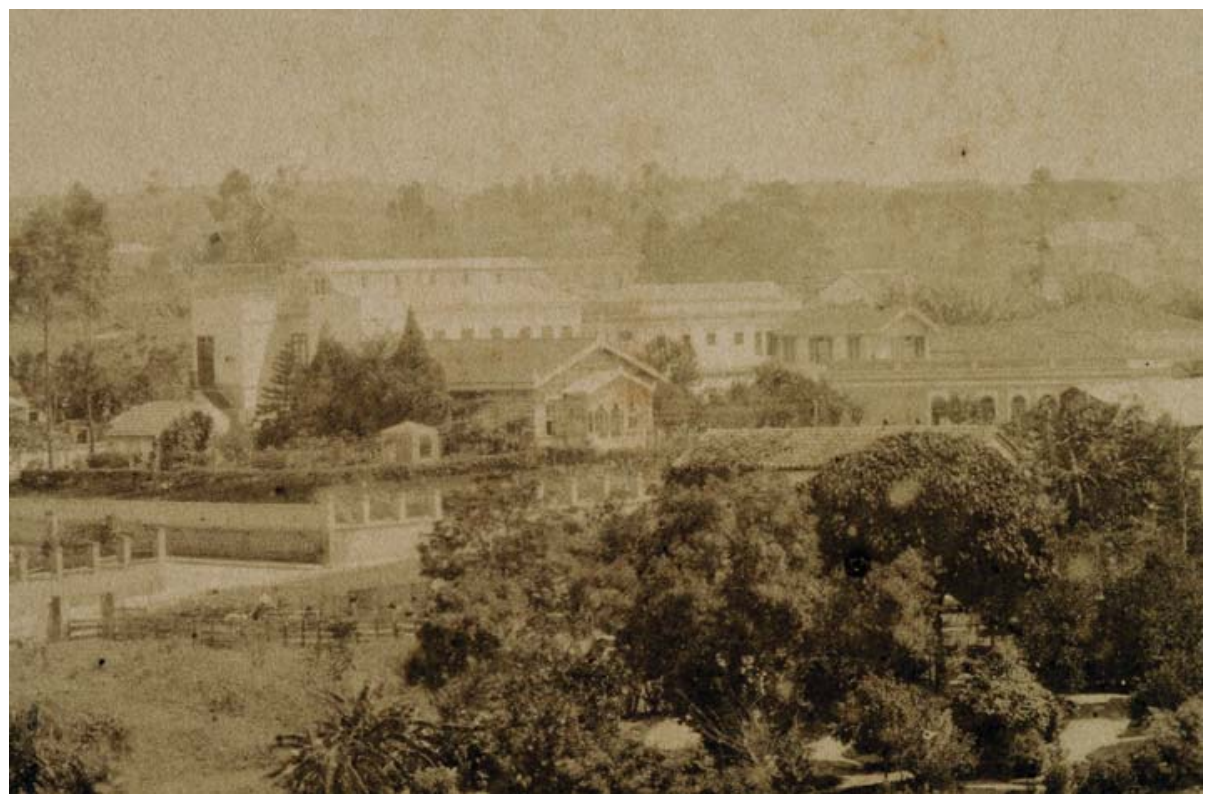

Figura $15 \mathrm{C}$ - Imagem de outro chalé, de proprietário não identificado, situado em um dos lotes onde mais tarde seria erguida a sede do Mappin. Detalhe da Figura 15A. Reprodução de José Rosael.

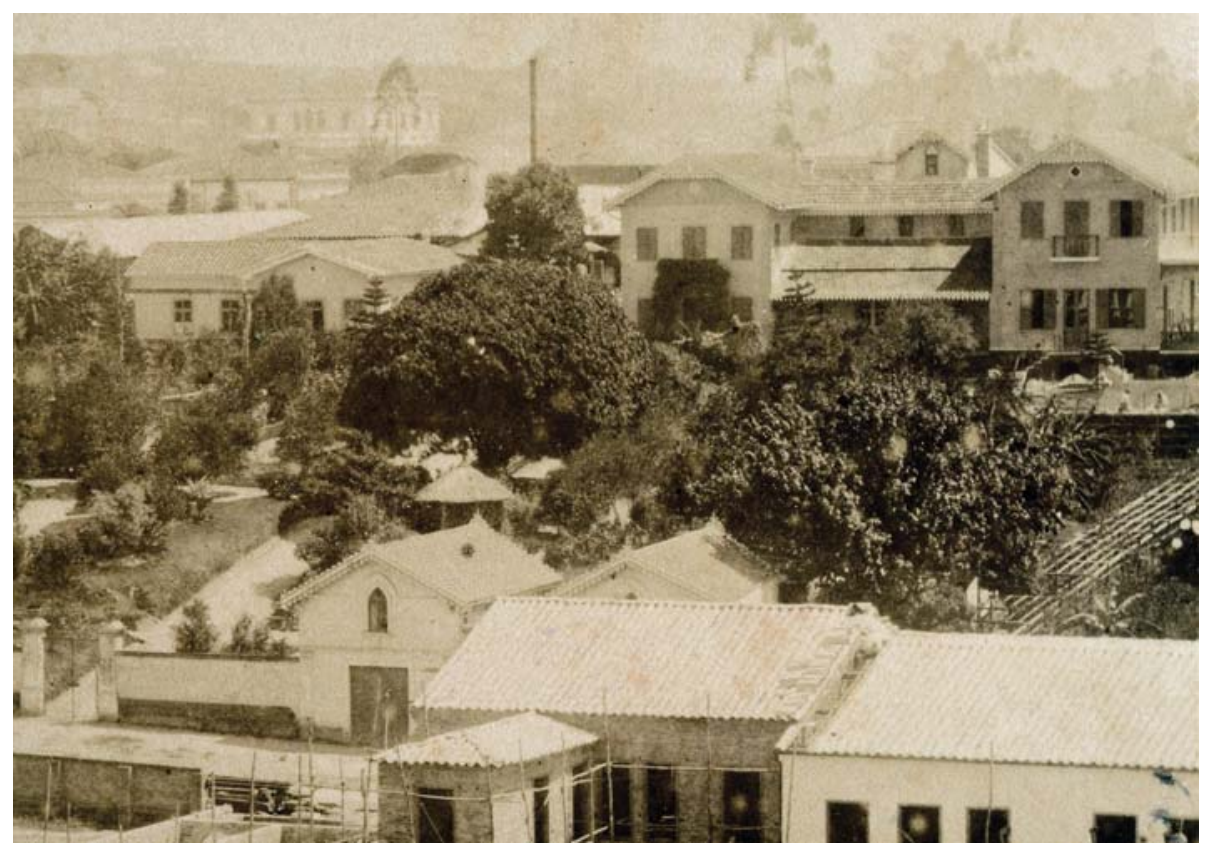

Figura 15 D - Vê-se em segundo plano a imagem da sede da chácara do coronel Proost Rodovalho, situada no morro do Chá, com entrada pela rua Formosa. Edificada em 1879 pelo mestre português Manuel Ferreira Leal, mostrava evidentes particularidades rurais. Em primeiro plano, vêem-se os dois anexos que deitavam sobre a rua Formosa (cocheiras, decerto), devidamente providos de telhados de chalé. Detalhe da Figura 15A. Reprodução de José Rosael. 


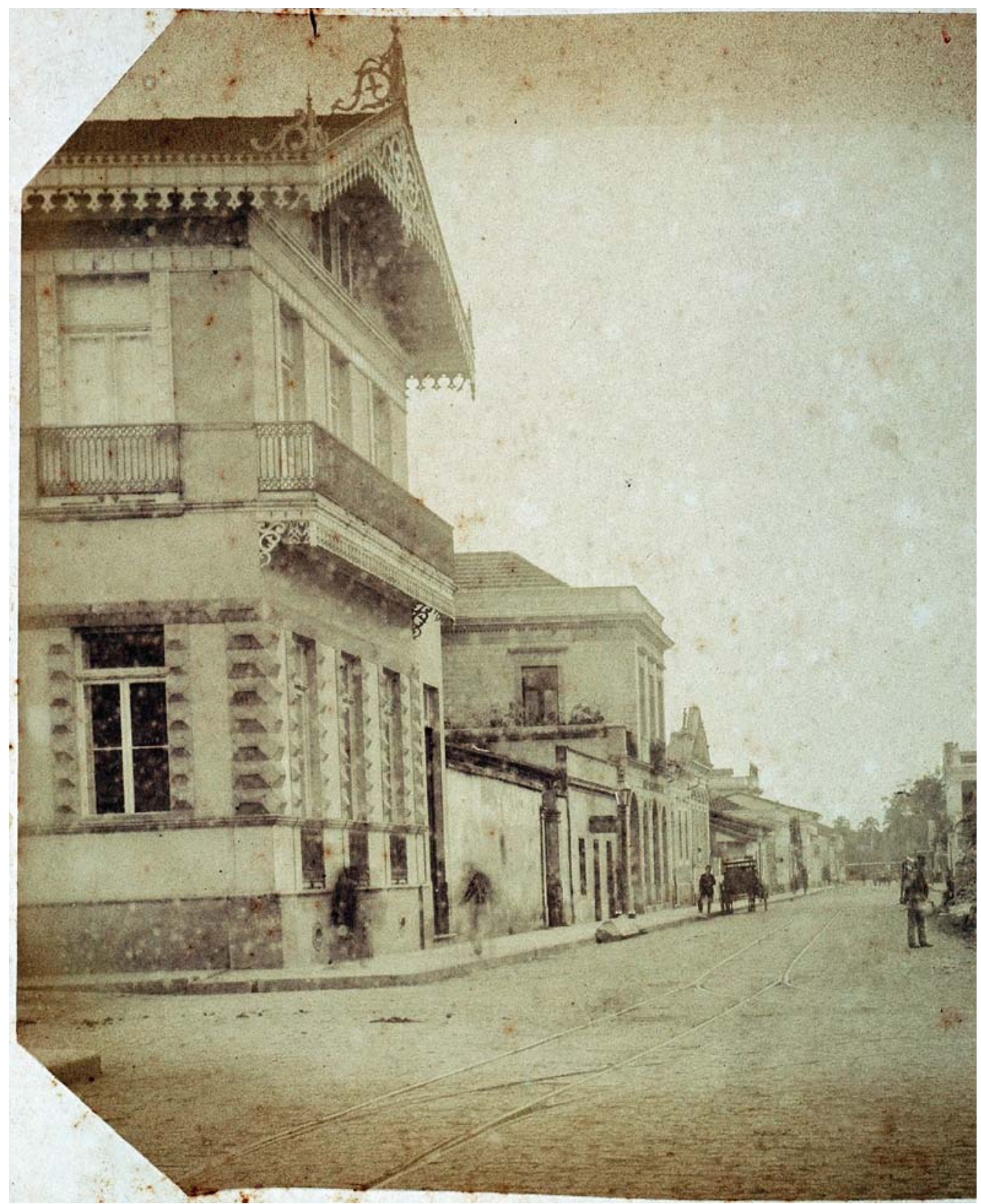

Figura 16 - À esquerda da imagem, da rua Brigadeiro Tobias, reconhecemos o sobrado em forma de chalé pertencente ao então conde de Três Rios. Militão Augusto de Azevedo. Detalhe da vista da antiga rua Alegre (Brigadeiro Tobias), 1887. Fotografia em Album comparativo da cidade de São Paulo. Acervo do Museu Paulista da USP, São Paulo. Reprodução de José Rosael. 


\section{COLLEGI0 AZEVEDO SOARES INTERNATO PARA MENINOS}

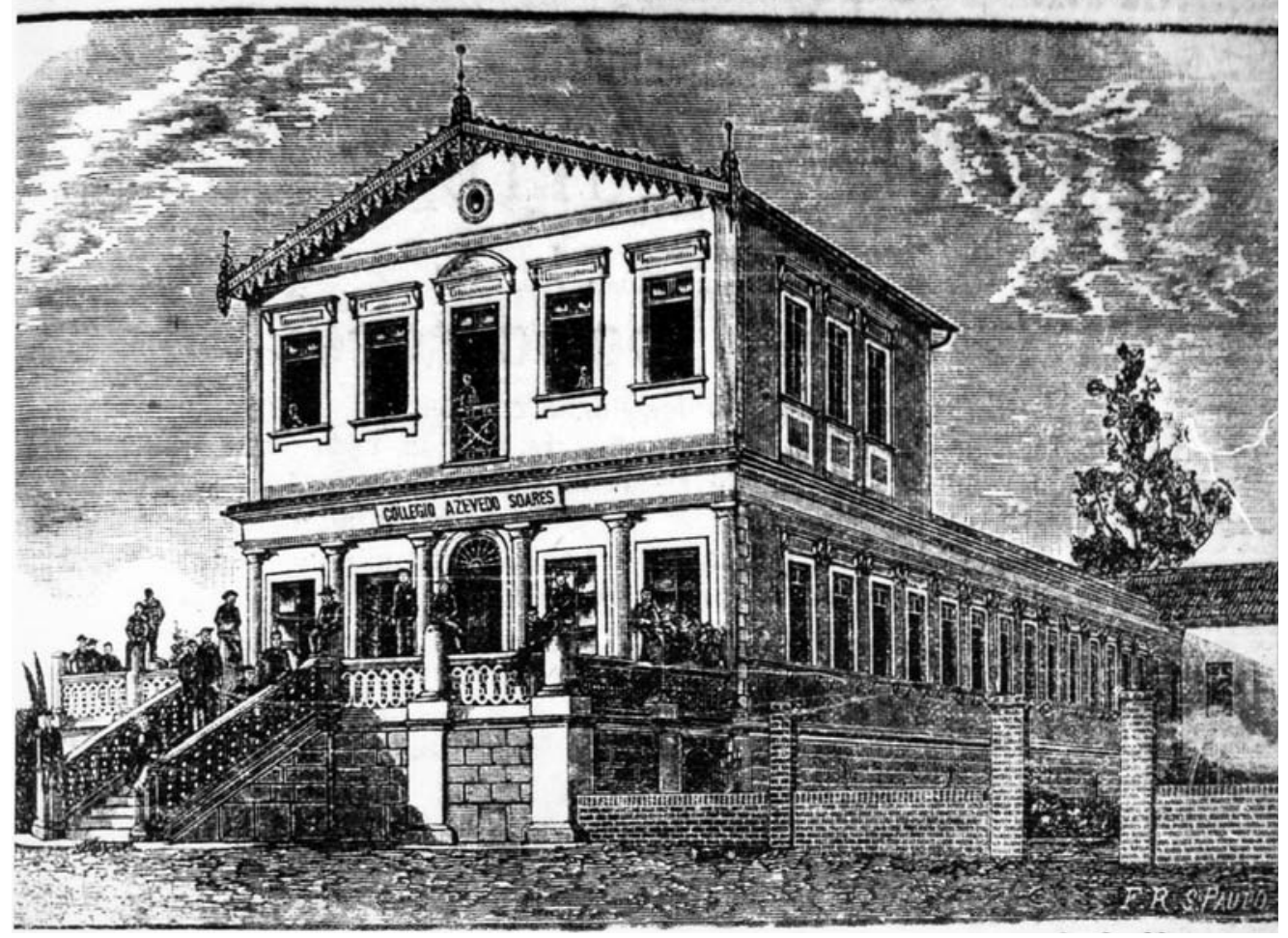

Figura 17 - F. R. (iniciais do artista). Colégio Azevedo Soares, situado na rua Monsenhor Andrade, no Brás. Litografia em anúncio. Em Almanach administrativo, commercial e industrial da Provincia de S. Paulo para o anno de 1887, [1887? ]. Acervo Biblioteca Mário de Andrade, São Paulo.

ainda mantinha sua aparência e uso originais, abrigando então a Escola Profissional Feminina ${ }^{49}$.

Nos papéis camarários depositados no Arquivo Histórico Municipal, ou em outras fontes documentais, encontramos ainda várias menções a chalés, infelizmente ainda não identificados em antigas imagens: havia um, por exemplo, sendo edificado, em 1881, na rua Conselheiro Crispiniano, esquina da rua 24 de Maio; outro, sito na rua Barão de ltapetininga, n. 6, onde estava instalado em 1887 o Colégio Paulistano, e o chalé do cônsul italiano dr. Perrod, na rua dos Timbiras, n. 4, entre muitos outros. Sabemos igualmente que d. Veridiana Prado, desde sua separação matrimonial ocorrida em 1877 até por volta de 1884, quando se mudou para a grandiosa vila no alto de Santa Cecília, morou num chalé na Luz, localizado nas proximidades da Estação Sorocabana, onde hoje está instalada a Sala São Paulo ${ }^{50}$. Na documentação do AHMWL, tivemos oportunidade de nos deparar também com um projeto de chalé datado de 1882. $\bigcirc$ interessado era um italiano de nome Polleone Bonadeni, que pretendia erguê-
49.VerA CAPITAL paulista... (1920, p. 95).

50. J. F. de Almeida Prado (1951, p. 50). 
51. SÃO PAULO (Cidade) (Obras particulares, v. 021, folha 167 e ss). lo sobre o leito do ribeirão Anhangabaú, junto da ponte da Abdicação (Figura 18). A construção, que se assentaria sobre pilares de alvenaria, contudo, jamais foi realizada, muito provavelmente por haver sido indeferido o pedido que o requisitante fez à Câmara Municipa| ${ }^{51}$. E, com relação aos chalés importados, temos notícia de que o dr. Domingos Jaguaribe, futuro sogro do arquiteto

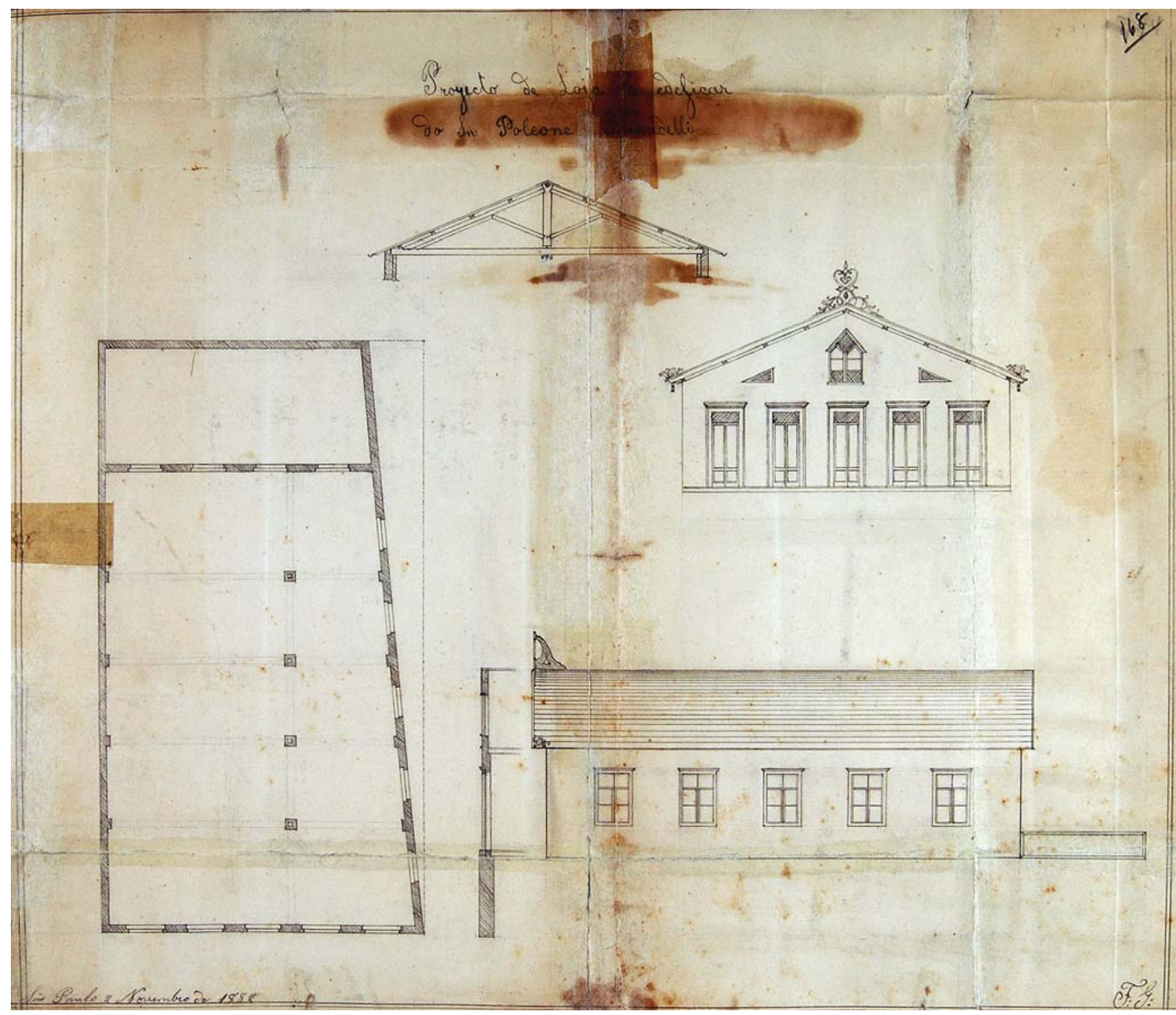

Figura 18 - Consultando a documentação do AHMWL, deparamo-nos com uma verdadeira raridade: um projeto arquitetônico datado do tempo do Império. Nessa época só havia necessidade de submeter às autoridades municipais paulistanas os projetos que saíam fora do padrão. No caso, o interessado, um italiano de nome Polleone Bonadeni, pretendia erguer um chalé sobre o leito do ribeirão Anhangabaú, junto da ponte da Abdicação. F. G. (iniciais do desenhista). Projeto de chalé de Polleone Bonadeni, 1882. Desenho técnico. Acervo do Arquivo Histórico Municipal (AHMWL), São Paulo. Reprodução de José Rosael. 
escandinavo Carlos Ekman, importara (por uma estranha coincidência, antes de conhecer o genro) uma casa pré-fabricada proveniente da Suécia, feita justamente na fábrica que, entre os anos de 1880 e 1884, pertenceu ao pai de Ekman ${ }^{52}$. Esse chalé seria, mais tarde (1905), transformado num dos pavilhões do Instituto Psicofisiológico, de propriedade do dr. Jaguaribe, segundo anunciado em revista médica da época (Revista Medica de S. Paulo) ${ }^{53}$.

Se excluirmos o chalé de Polleone Bonadeni, cujo projeto arquitetônico, por se revestir de características especiais, teve de ser submetido às autoridades municipais em 1882, todos os demais casos retrocitados, construídos durante o Império, ou nos são conhecidos apenas por fotografias ou ilustrações que registraram seu aspecto exterior, ou por meio de meras referências escritas, já que só a partir de 1893 a Câmara Municipal começou a exigir, de maneira sistemática, a apresentação de plantas arquitetônicas para a concessão de licenças para construir (Lei n. ${ }^{\circ} 38$, de 24 de maio desse ano). Em vista disso, pouco conseguimos apurar acerca de seus respectivos programas de necessidades ou de seus agenciamentos internos. Tudo leva a crer, no entanto ao menos no caso dos chalés de destinação residencial -, fossem tão europeizados em sua parte interna quanto o eram externamente. Para termos uma noção de como seria o interior dessas construções, em geral amplas e confortáveis, faz-se necessário recorrer a descrições presentes em anúncios de jornal. Num número do Correio Paulistano de 1885, por exemplo, colhemos a que se segue:

\section{Aluga-se}

O chalet n³3 da rua do Gazometro com excellentes commodos para familia, agua da Cantareira, banheiro de chuva, cosinha com fogão economico, água e lavatorio de louça, gaz em toda a casa, grande quintal com excellentes fruteiras, tanque para lavar roupa, plantas de qualidade, jardim com viveiro e cascata. A casa é cercada de varandas, muito arejada, com janellas para todos os lados, terreiro cimentado, com exgottos, gallinheiro de arame, bonds á porta, etc.etc.

Tratar-se na mesma rua nำ17, onde está a chave..$^{54}$

Poucos dias depois vinha à luz outro anúncio de venda de chalé. Desta feita fazia-se uma mais pormenorizada descrição desse tipo de propriedade, que se localizava na região chamada Ponte Preta. Segundo Nuto Santana ${ }^{55}$, esta paragem ficava no Brás, num ponto que no começo do século XIX era chamado Nicolau, nas proximidades da futura Estação do Norte, inaugurada em 1877.

\section{Alto Negocio}

Nestes tempos de crise e falta de dinheiro / LELIĨ̃O / Ao correr do martello / De um / Predio nobre e confortavel / Venda forçada e terminante / por / Conta e ordem de quem pertencer / Roberto Tavares / Sem reserva nem limites e em tres gritos! / Entregará ao maior lance / Quinta-feira, 28 as $41 / 2$ horas da tarde / UMA RICA E BELLISSIMA / PROPRIEDADE / no / Braz Ponte Preta / o grande e rico chalet / conhecido pelo de Jacob Friederichs / APOSENTO / Quatro grandes salões, um vasto refeitorio, 14 quartos com janellas, ditos de creados,
52. Maria Cecília Naclério Homem \& Lúcio Gomes Machado (1976, p. 45; 49).

53. Informação prestada ao autor, em março de 2008, pela pesquisadora Maria Lucia Mott, do Museu da Saúde Emílio Ribas, a quem muito agradecemos.

54. Cf.ALUGA-SE.

55. Ver Nuto Sant'Anna (1937-1944, v. 4, p. 218). 


\section{Cf.ALTO negocio}

57.Ver Ernani Silva BRUNO (1981.p. 92); Pedro Corrêa do LAGO (1998, p. 174).

58. Ver SÃO PAULO (cidade) (Atas, 1948, v. 49. p. 10). grande cosinha, gallinheiro e gaz em todo o edifício. / Bello Jardim / Cultivado com boas e raras flores, repuchos, pilhas, cisternas, drainagens de exgotto, etc. / Chacara / Igualmente com arvoredos de qualidade todas frutiferas, sendo algumas estrangeiras e bem aclimadas, extenso parreiral, capim e pasto para quatro animaes, etc. etc. / Que esta bellissima propriedade está acabada ha bem pouco tempo e seu dono fel-o para a sua residencia não poupando dinheiro nem sacrifícios para dotal-a com todo o confortavel e hygienico. Tem o predio 44 metros de frente e o terreno tem de fundo 224 ditos. / Condições unicas / 205 de signal no acto do leilão / Escriptura no praso improrrogável de oito dias. ${ }^{56}$

Num desenho a lápis que tem por motivo o aterrado do Gasômetro, importante obra pública executada no tempo da construção da primeira fábrica paulistana de gás de iluminação (1870-1872), pode ser visto, ao fundo, mais um aprazível chalé daquela época. De autoria de um artista desconhecido, de origem alemã, que se assinava com as iniciais W. K., o desenho, datado de 1883, integrou durante certo tempo a coleção do historiador Ernani Silva Bruno ${ }^{57}$. $\mathrm{Na}$ obra, vemos em primeiro plano a Ponte do Mercado, erguida em $1872^{58}$, sob a responsabilidade do empreiteiro de obras públicas Antônio Bernardo Quartim. E, ao fundo, erguido no Brás, na rua do Gasômetro, bem junto da várzea e em frente à fabrica de gás, à esquerda do observador postado aquém-Tamanduateí, está posicionado o chalé em questão. Tinha três pisos e era rodeado de balcões. A planta, ao que parece, possuía a forma aproximada de um T, em razão da existência de um corpo avançado numa das fachadas laterais (Figuras 19 e 20).

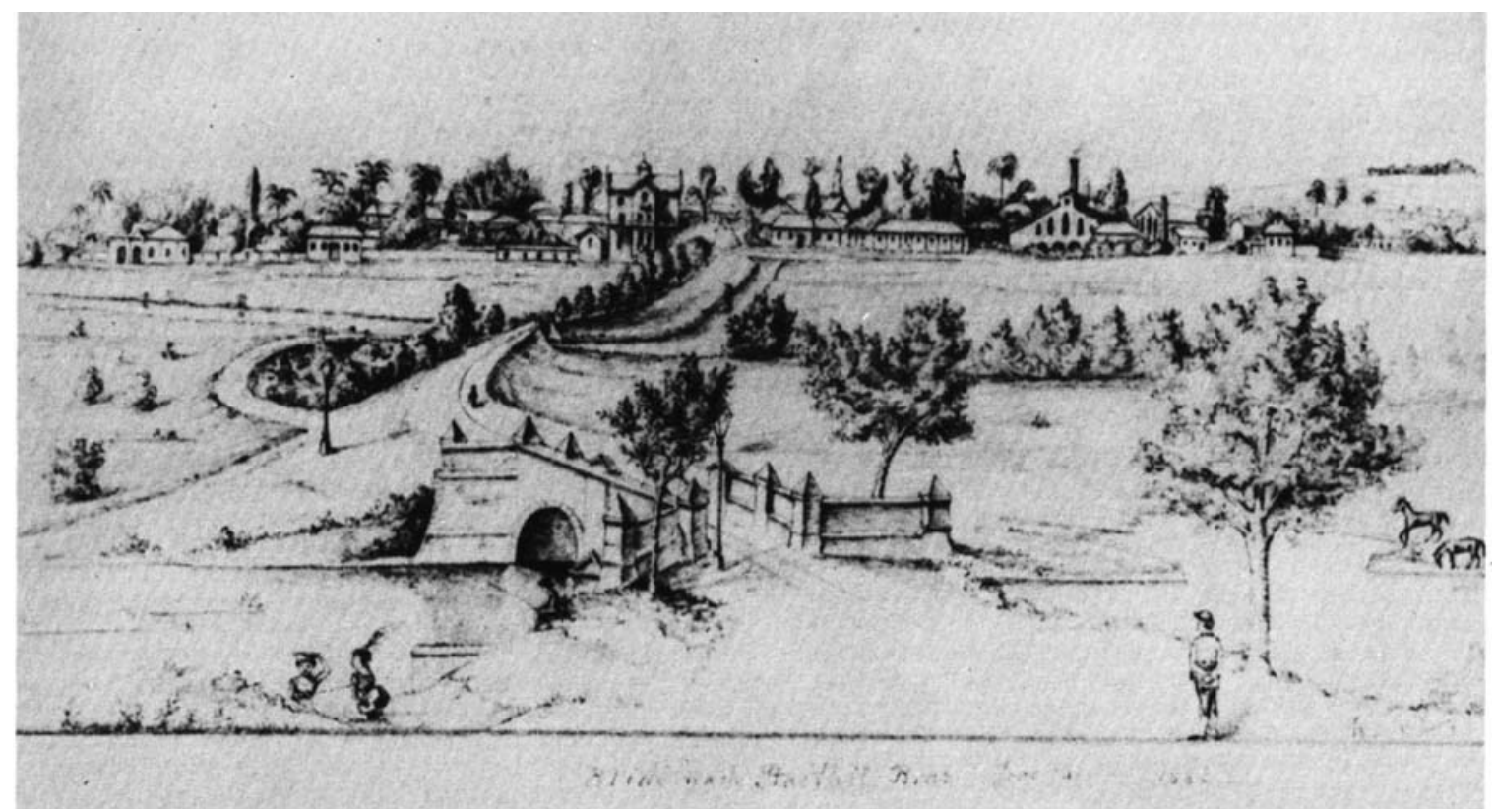

Figura 19 - De autoria de um artista desconhecido, de origem alemã, que se assinava com as iniciais W. K., o desenho integrou a coleção do historiador Ernani Silva Bruno. Hoje seu paradeiro é ignorado. Em primeiro plano, a ponte construída, em 1872, por Antônio Bernardo Quartim. Ao fundo, o chalé que serviu de clínica do dr. Carlos Botelho (c. 1886-1891), ao que dizem desaparecido por volta da década de cinqüenta do século passado. W. K. (iniciais do artista). Vista do aterrado do Gasômetro, 1883. Desenho a lápis. Em Ernani Silva Bruno (1981) 


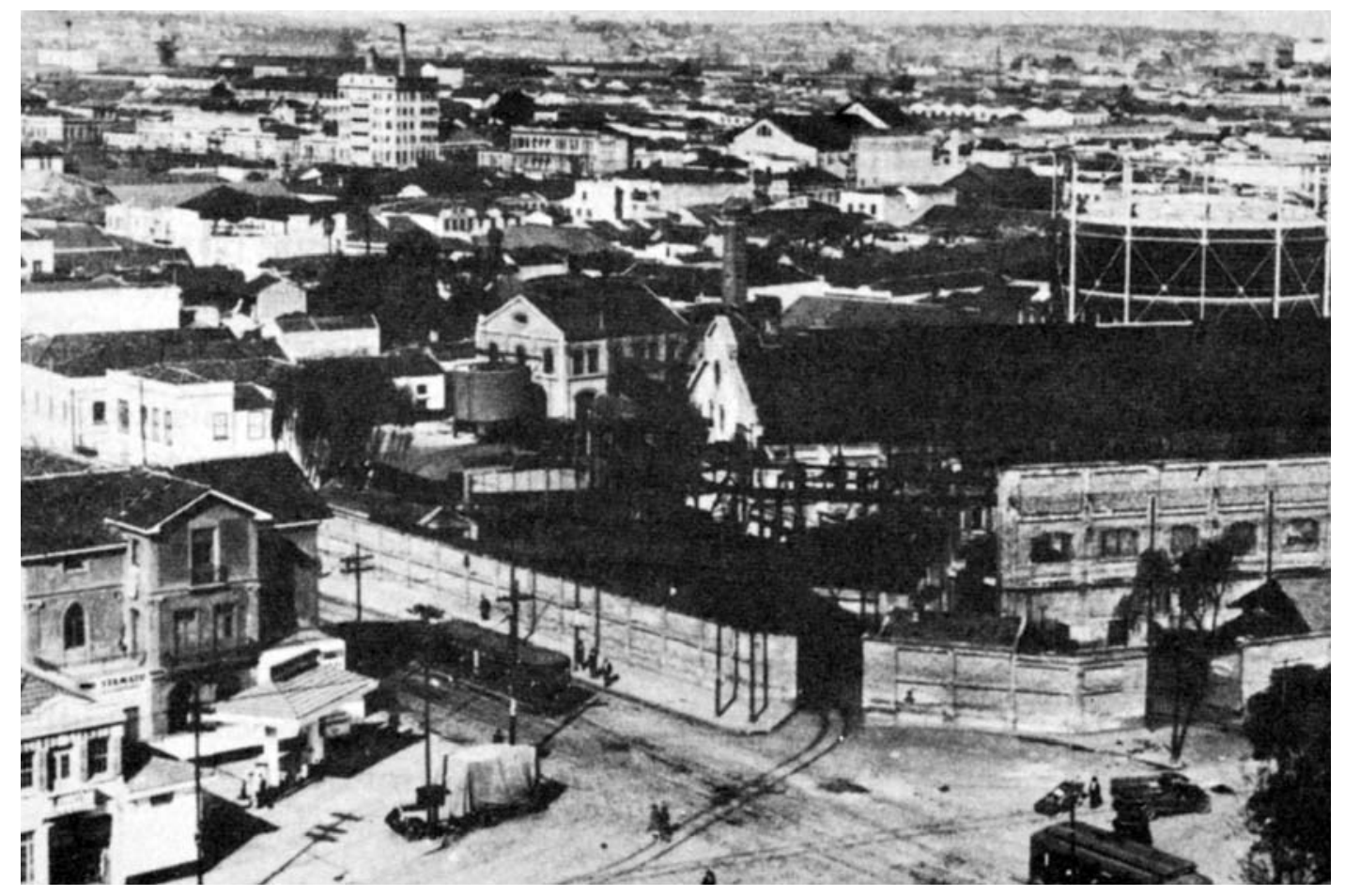

Figura 20 - Anônimo. Aspecto do Gasômetro, no Brás. À extrema esquerda da imagem, chalé usado como sede da clínica do dr. Carlos Botelho, 1932. Fotografia. Em Geraldo Sesso Jr. (1983).

Por volta de 1884 - a exemplo do Chalet Olinda (construído em torno de 1850 e que leva o apelido de seu primeiro proprietário, o marquês de Olinda) de Botafogo, no Rio de Janeiro, que abrigava a Casa de Saúde Dr. Peixoto -, aí se estabeleceu o primeiro hospital particular da cidade pertencente a um médico, no caso, o dr. Carlos José de Arruda Botelho (1855-1947), filho do conde do Pinhal. $\bigcirc$ Instituto Hidroterápico e Cirúrgico desse famoso urologista, formado em Montpellier e em Paris, foi seguidamente anunciado nos almanaques paulistanos entre 1884 e 1891, passando depois o chalé da rua do Gasômetro a ser sede do sanatório do dr. Tapaiós e dr. Fausto ${ }^{59}$. $\bigcirc$ endereço desse chalé correspondia ao n. 1 da rua do Gasômetro, mas isso se deu após a reordenação da numeração dos imóveis paulistanos ocorrida entre 1885 e 1886, quando ficou determinado que, na numeração seqüencial, os números ímpares ficariam do lado esquerdo das vias públicas, e não ma is à direita, como vinha acontecendo desde 1865. A partir dos anos de 1920, ficou o antigo chalé fechado e abandonado, tornando-se uma conhecida - e temida - ruína mal-assombrada, até ser demolido cerca de 1950. Um triste fim para uma construção semi-rural outrora tão agradável, sede da primeira clínica ou casa de saúde da cidade, onde dr. Carlos Botelho manteve durante anos um jardim de aclimatação de espécies raras, então muito apreciado e conhecido ${ }^{60}$

De todos os chalés erguidos ao longo do século XIX nenhum sobreviveu. Na rua Roberto Simonsen, n. 136-B, resta uma construção que, embora não sendo
59. As informações sobre a clínica do dr. Botelho nos foram prestadas pela pesquisadora Maria Lucia Mott, a quem mais uma vez agradecemos.

60. Ver Geraldo Sesso Jr. (1983, p. 89; 91); e, também, Carlos Botelho. 
um típico chalé suburbano, guarda algumas de suas características decorativas. Trata-se de um sobrado de três pavimentos, com nítidas feições urbanas /sem recuos em relação à testada e às divisas laterais do lote e com a entrada principal diretamente voltada para a rua), construído para servir de residência para seu rico proprietário, o major Benedito Antônio da Silva (Figura 21 ). A marca distintiva

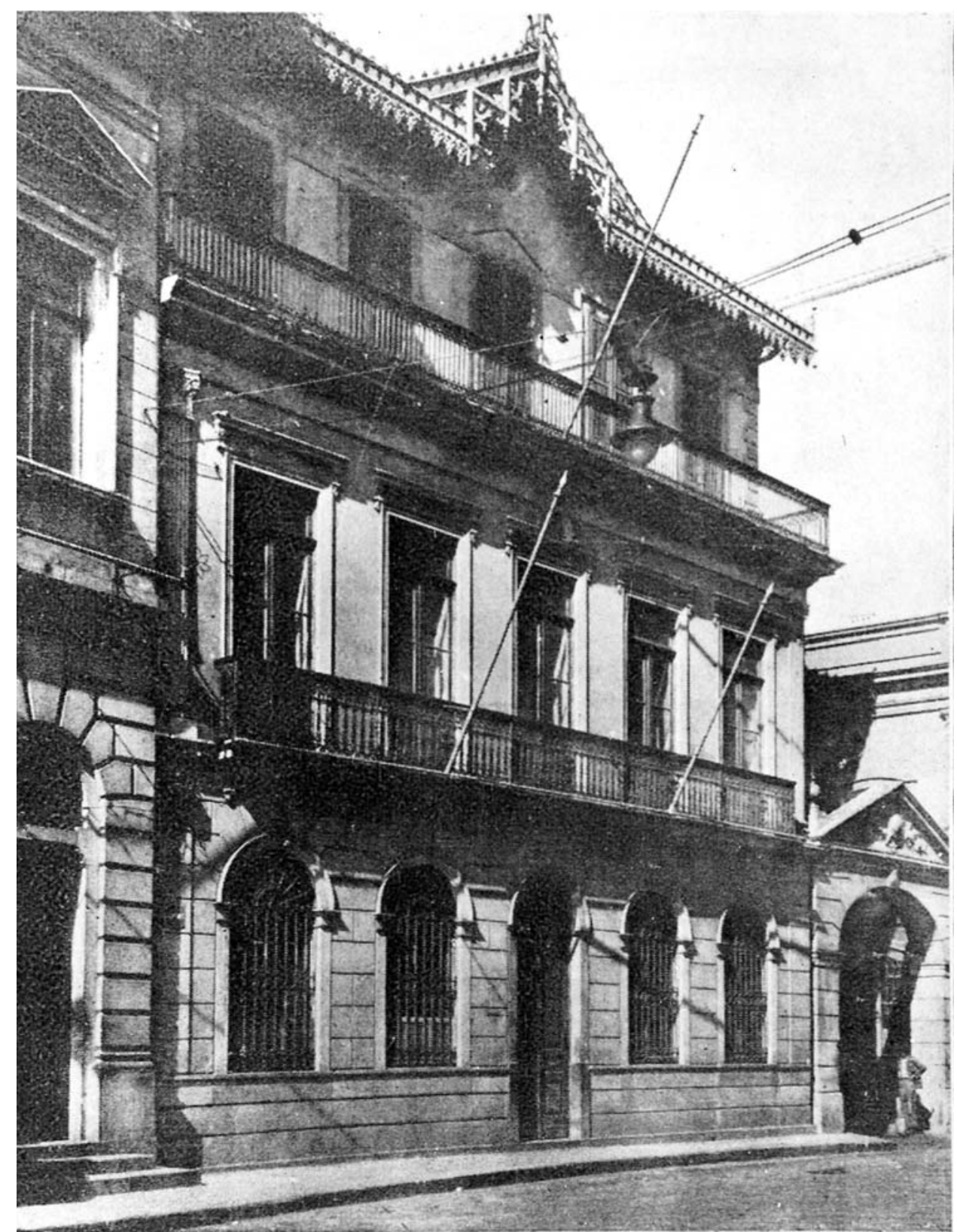

Figura 21 - Anônimo. Antiga residência do major Benedito Antônio da Silva lem construção no ano de 1880), década de 1920. Fotografia. Acervo da Divisão de Iconografia e Museus, Departamento do Patrimônio Histórico, São Paulo. 
do chalé, neste caso, restringe-se aos beirais lambrequinados, que contornam a edificação, e às testeiras da pequena empena central, que coroa a água-furtada existente no alto da fachada principal.

Ao tempo de sua construção, esse edifício se tornou objeto de detida análise por parte da Câmara, em virtude de uma representação encaminhada por vizinhos, que denunciaram o proprietário por ter aberto uma porta na parede lateral direita, aproveitando o recuo que as moradias contíguas mantinham em relação ao sobrado. Pretendiam gradear as testadas de suas propriedades, formando pequenos jardins fronteiros, como então começava a entrar em moda, e a presença daquela porta prejudicava-lhes o intento ${ }^{61}$.

A comissão encarregada de estudar o problema chegou a duas alternativas: ou a Câmara considerava os imóveis dos queixosos como situados na rua do Carmo (atual Roberto Simonsen) e permitia, em conseqüência, o avanço das frentes das edificações (mas não o desejado gradeamento das testadas), ou considerava-os voltados para o largo de Palácio, não tendo, nesse caso, direito de se orientarem pelo alinhamento daquela via pública ${ }^{62}$.

Infelizmente, não nos é conhecida a decisão final dos vereadores, porque o julgamento acabou adiado e na documentação camarária nada mais consta sobre o assunto. No entanto, as circunstâncias levam-nos a deduzir que a Câmara afinal se pronunciou, e, quando o fez, foi em favor do proprietário do sobrado, ofuscada decerto pelo prestígio social do denunciado. Quanto aos reclamantes, negou-se-lhes a pretensão de regularem o alinhamento de seus prédios pelas testadas da rua do Carmo, sem dúvida sob a alegação forçada de que os imóveis tinham por endereço o largo de Palácio.

Certificamo-nos disso não só por estampas do final do Oitocentos que perpetuam imagens daquela parte da cidade, como também pelo novo sistema de numeração das casas de São Paulo, adotado por volta de 1885 ou 1886. Por esse sistema, o sobrado que até então correspondia ao n. 81 passou a ostentar o n. 1 da rua do Carmo. Expediente que trai a interpretação, adotada anos antes pela Câmara, de que as residências à direita do sobrado achalezado não pertenciam àquela rua, mas ao logradouro vizinho.

Mais tarde, as casas velhas dos vizinhos prejudicados na questão foram derrubadas e, no lugar, fez-se o palácio da Secretaria da Justiça (1896), obra do escritório do arquiteto Ramos de Azevedo. Construção que, ao obedecer, como era lógico, ao alinhamento das demais edificações da rua do Carmo, provocou o fechamento dos vãos laterais do sobrado, àquela altura não mais pertencente ao influente major. Só quando foi demolida a antiga sede da Secretaria da Justiça, em meados do século XX, é que reapareceram entaipadas a porta do térreo e as envasaduras dos andares superiores na empena do sobrado vizinho, aberturas que foram devidamente reconstituídas durante os trabalhos de restauração realizados no imóvel acerca de vinte e cinco anos atrás.

Junius - em seu livrinho sobre São Paulo, editado pela primeira vez em 1882 - traçou breves linhas a respeito do proprietário da casa n. 1 da rua do Carmo. Embora o autor das notas explicativas incluídas na reedição de 1978 não tenha conseguido identificar o retratado, conseguimos fazê-lo com sucesso. 
63. Cf. Firmo de A. Diniz (Junius) (1978, p. 49).

64. No bairro de Vila Buarque, na esquina da rua Rego Freitas com a General Jardim, havia um sobrado de tipologia bem parecida com a casa do major Benedito, que acabamos de ver. De três pavimentos, estava coberto com telhado de largos beirais e pequenas empenas coroando os frontispícios, tudo contornado com lambrequins, tal como ocorre ainda hoje no sobrado da rua Roberto Simonsen.A decoração externa da construção indicava datar dos anos 1890 e, apesar de estar em mau estado, conservou-se externamente íntegro até o ano de 1975 , mais ou menos. Por essa época, os beirais foram re movidos, e platibandas precárias, erguidas no lugar. Anos depois, as envasaduras foram alteradas e o revestimento das paredes, totalmente refeito. Esse prédio talvez tenha sido um dos últimos sobrados urbanos a serem construídos com detalhes pitorescos de chalé.Ainda permanece em pé, mas nele já não é possível reconhecer nenhum traço de sua aparência original. Oxalá algum arquiteto apreciador de construções antigas o tenha fotografado em seu estado primitivo, pois, afinal, está localizado bem em frente à sede do Instituto dos Arquitetos do Brasil-SP (IAB).
Por um diálogo mantido com uma personagem chamada dr. Z..., Junius toma conhecimento de que o major B... morara em Santo Amaro e, graças a seu dinamismo e tino comercial, por incrível que pareça, aí enriquecera. Depois de rico, mudou-se para São Paulo e desde então se servia de parte de sua fortuna para o embelezamento da cidade. Perguntado como fazia isso, respondeu o dr. Z:

É fácil compreender-se: o Major compra casas velhas, verdadeiras ruínas, manda demolilas e sobre seu solo levanta lindos palacetes, e acrescentou, lamento que ele não tenha o décuplo da fortuna que aqui [em Santo Amaro] alcançou fazer, creio que com ela daria nova feição a muitas ruas da Capital pela construção de bonitos edifícios ${ }^{63}$.

Entre os bonitos palacetes erguidos por esse major da Guarda Nacional, um dos empresários promotores da renovação e expansão edilícia paulistana durante o primeiro grande surto imobiliário experimentado pela Capital, achava-se seguramente o sobrado achalezado de que vimos tratando, em plena construção no ano de 1880.

Ainda por outras razões, o sobrado acima mencionado é notável. Do ponto de vista tipológico, mostra-se relevante por manter, ainda que tardiamente, o conceito de piano nobile, ao reunir no primeiro andar as principais peças de representação (salas de visita e sala de jantar). Do ponto de vista artístico é igualmente importante, pois conserva algumas pinturas murais em áreas de circulação vertical e horizontal. Compostas de grutescos um tanto ingênuos, representam arranjos florais, putti e paisagens. De autoria desconhecida, constituem valioso documento artístico, havendo sido os seus vestígios objeto de recuperação no ano de $1991^{64}$.

Em fins do Império, as primeiras disposições normativas sobre chalés

Durante o período áureo do chalé, a airosa cobertura de duas águas, ornada com rendas de madeira, acabou por ganhar status de verdadeira marca civilizatória, já que sua simples presença garantia, na opinião da maioria do público contemporâneo, a qualidade estética, o poder evocativo e a modernidade das construções em que comparecia.

Dada sua grande popularidade, o chalé acabou por ser apropriado de maneira desregrada. A cobertura de duas águas afrontou as convenções do ecletismo tipológico-estilístico e passou a adornar não só edifícios residenciais nos subúrbios, como era prescrito pelas Academias de Belas-Artes, mas também edifícios comerciais em áreas centrais das cidades, inclusive na própria Corte. Essa transgressão de regras acadêmicas era, supomos, involuntariamente cometida pelos mestres-de-obras, profissionais de nível oficinal, possuidores de conhecimentos construtivos empíricos e práticos, mas desconhecedores das teorias estéticas eruditas. Diante dessa incorreção, que tanto incomodava as 
autoridades, foi necessário restringir a construção de novos chalés, o que em São Paulo aconteceu a partir do padrão posto em vigor em fevereiro de $1889^{65}$.

Esse padrão edilício municipal, o último dos tempos imperiais, superou os padrões paulistanos anteriores, na medida em que absorveu conceitos da arquitetura eclética erudita que triunfava no Exterior, mas que ainda surgia timidamente na cidade de São Paulo. Já mencionamos o fato do padrão admitir balcões de madeira (banidos anteriormente pelo artigo n.ำ 24 do código de 1875) desde que complementassem construções do tipo chaléb, afinal a madeira era um material inerente a esse tipo construtivo de origem rural. Por outro lado, proibiu a construção de chalés dentro do perímetro comercial lo famoso Triângulo, formado pelas ruas da Imperatriz, atual 15 de Novembro, São Bento e Direita). Tal restrição pode ser atribuída ao aparecimento de prédios de comércio no centro da cidade com os característicos telhados de duas águas marginadas de lambrequins, uma incorreção que viera da Corte, onde o engenheiro Vieira Souto já censurava em 1875 essa manifestação de progresso urbano desorientado: "E que diremos dessa conhecida forma de chalet tão propria para os arrabaldes, quanto absurda para ser adotada na rua do Comércio, como já se vai fazendo entre nós?"b7.

Em São Paulo, por meio de fotos antigas, podemos identificar com facilidade alguns chalés de destinação comercial, ou ao menos de destinação mista, na rua João Alfredo (atual General Carneiro), no largo São Bento e na Florêncio de Abreu (Figuras 22-24).

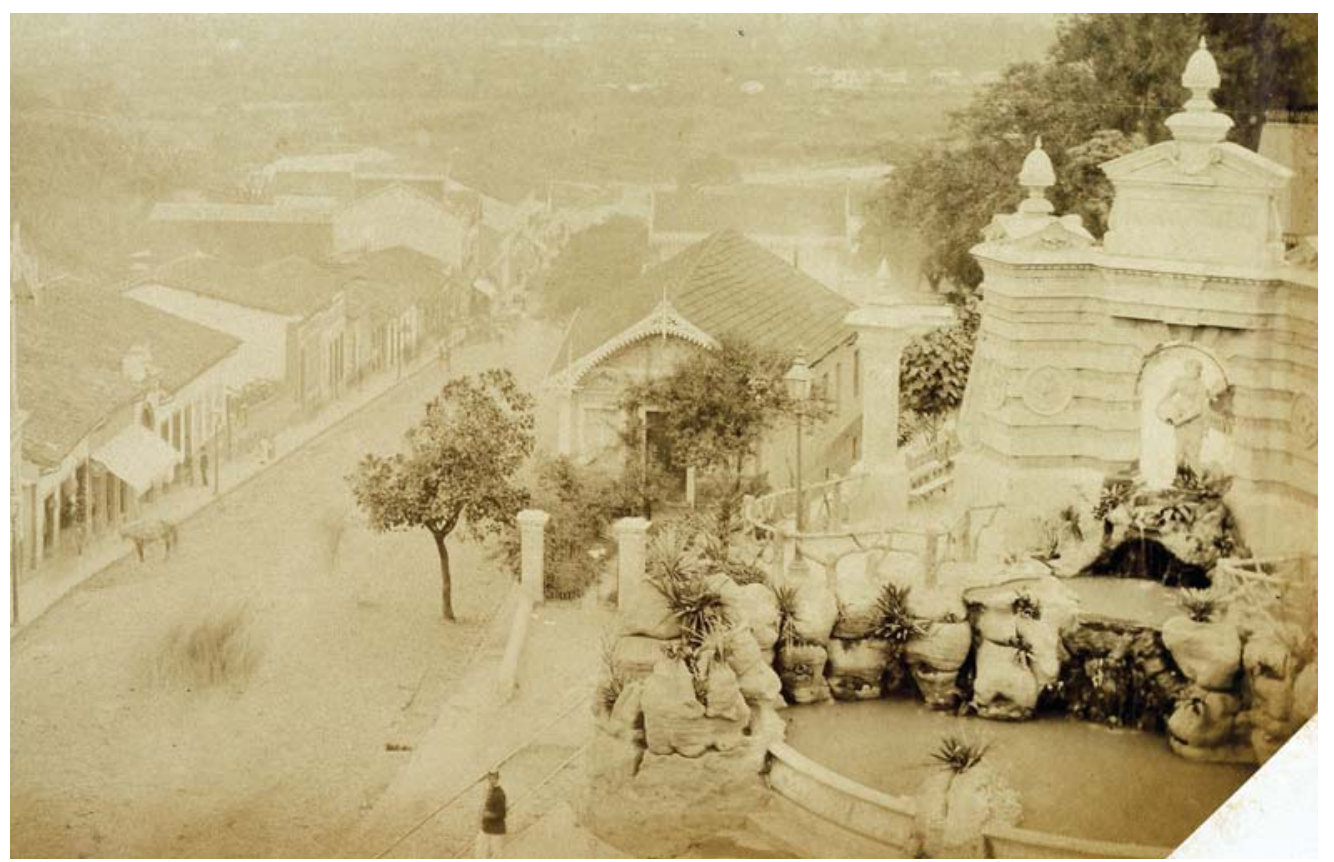

Figura 22 - Por meio de fotos antigas, podemos identificar alguns telhados de chalés em prédios de destinação comercial, ou ao menos de destinação mista, na proximidade do chamado Triângulo. Militão Augusto de Azevedo. Vista da rua João Alfredo (detalhe), 1887. Fotografia em Album comparativo da cidade de São Paulo. Acervo do Museu Paulista da USP, São Paulo. Reprodução de José Rosael.
65. Eudes Campos (1997, cap.7, p. 719).

66. Idem, v. 3, p. 609.

67. Gilberto Freyre (1959, cap.2, p. 213). 
68. Eudes Campos (1997, cap.6, p. 599). Ver também foto de autoria de Guilherme Gaensly \& Lindermann em IMAGENS de São Paulo (2001, p.128-129). À extrema direita da foto, vê-se prédio já existente em 1887 , com águas-furtadas decoradas com lambrequins, à moda dos chalés.
As duas águas lambrequinadas passaram a freqüentar também o topo de águas-furtadas. A rigor, as águas-furtadas estavam proibidas nas novas construções paulistanas quando situadas na parte das coberturas que ia da cumeeira para a frente, ou seja quando situadas em pontos dos telhados visíveis da rua (segundo o artigo 16 do Código de 1875, que copiava uma postura aprovada na Corte no remoto ano de $18511^{68}$. Difundidos no Brasil no decorrer dos Setecentos, esses elementos arquitetônicos agora eram tidos como fator de enfeamento dos frontispícios. Tal proibição, porém, não foi seguida à risca, graças à moda dos chalés. Os proprietários decidiram alegrar as trapeiras de seus prédios com as duas águas lambrequinadas, e assim foram elas toleradas pelas autoridades locais nas décadas posteriores, como nos mostram registros fotográficos datados dos anos de 1880 e 1890 - fenômeno, aliás, que também ocorreu no Rio de Janeiro.

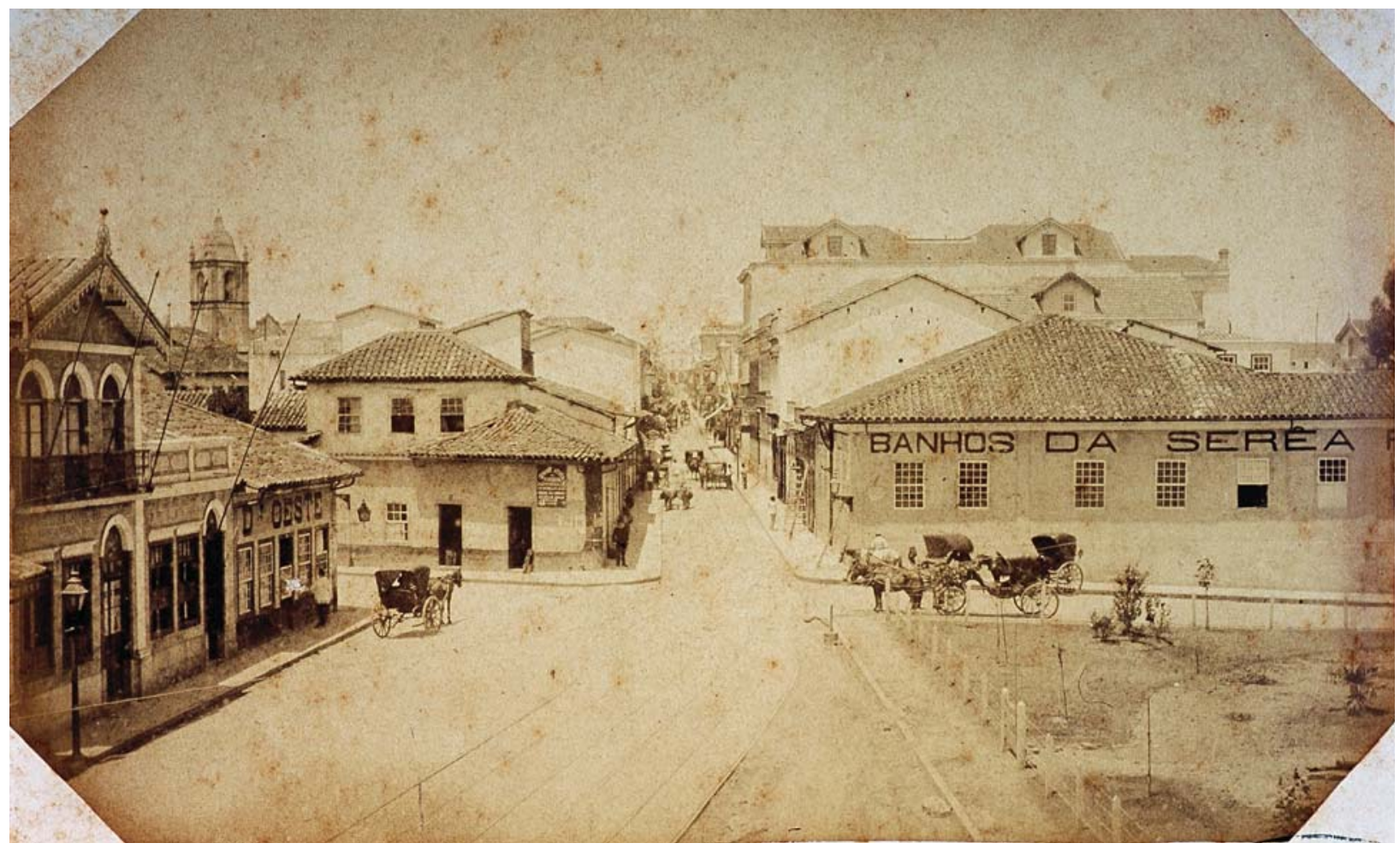

Figura 23- À extrema esquerda, próximo do Hotel do Oeste, situado na esquina, vê-se um pequeno sobrado em forma de chalé. Mais tarde, o hotel englobaria as construções vizinhas e a construção da esquina também adquiriria feições de chalé. No fundo, na rua São Bento, à direita, observa-se a empena de um prédio de três pisos cujo telhado estava pontoado de águas-furtadas, construção anterior a 1887. Embora proibidas desde 1875 quando visíveis da rua, as águas-furtadas do referido edifício foram toleradas, graças, certamente, ao fato de estarem adornadas com os elementos típicos dos chalés suiços. Militão Augusto de Azevedo. Vista do largo São Bento (detalhe), 1887. Fotografia em Album comparativo da cidade de São Paulo. Acervo do Museu Paulista da USP, São Paulo. Reprodução de José Rosael. 


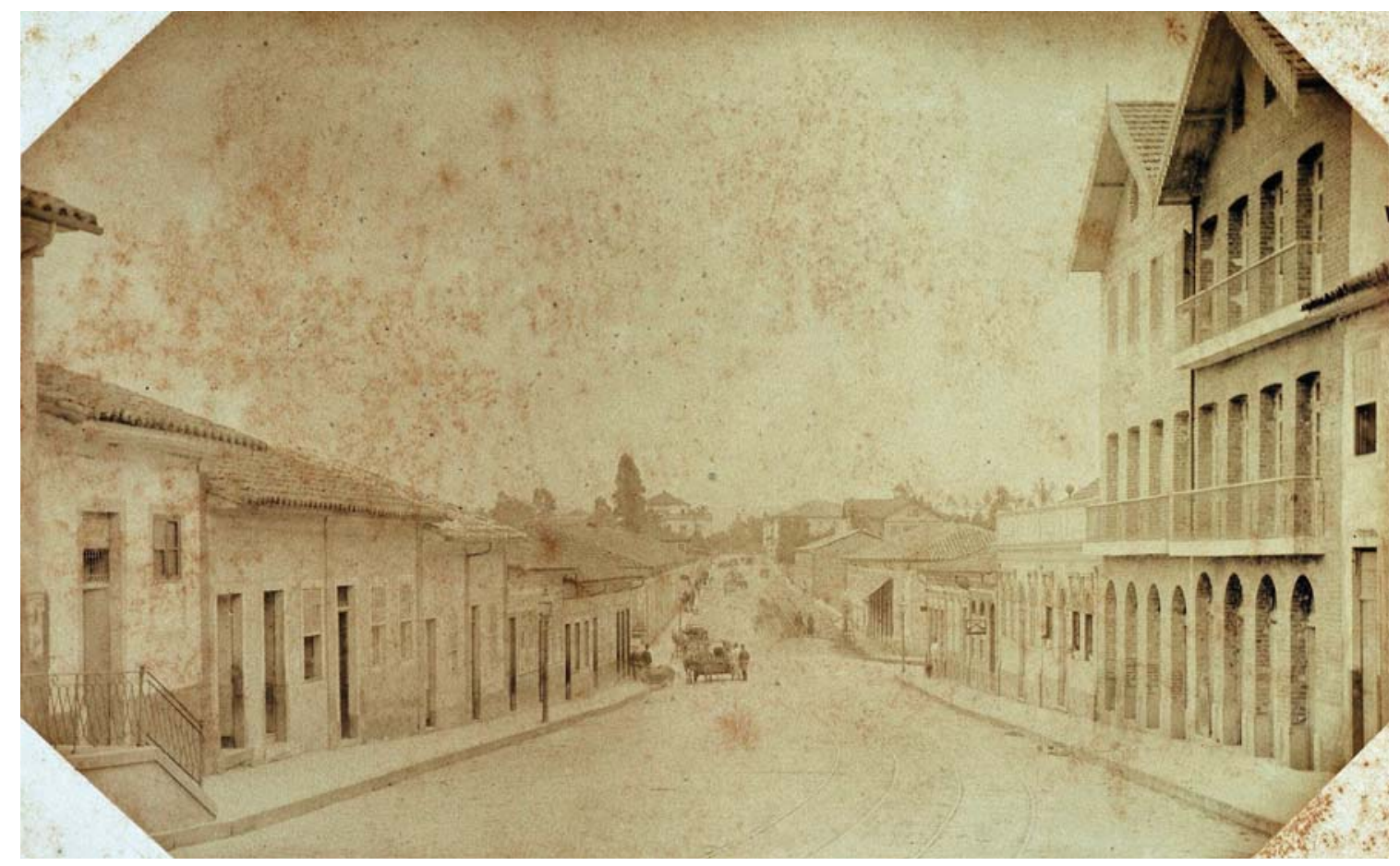

Figura 24 - À extrema direita da foto, dois sobrados de três pisos com telhados de chalé. Militão Augusto de Azevedo. Vista da rua Florêncio de Abreu, 1887. Fotografia em Album comparativo da cidade de São Paulo. Acervo do Museu Paulista da USP, São Paulo. Reprodução de José Rosael.

Disseminação dos elementos decorativos dos chalés em outros tipos de edificação

A popularidade dos chalés fez com que os elementos decorativos típicos das coberturas dessas construções passassem a guarnecer telhados de mirantes - corpos estreitos, situados acima da linha da cimalha e mantidos recuados em relação às fachadas das casas, o que lhes dava o ar enganoso de acréscimos posteriores. Os mirantes haviam-se tornado nessa época muito comuns em São Paulo, sobretudo em construções que representavam uma forma popular de ecletismo arquitetônico. As frontarias dessa espécie de edifício residencial exibiam amiúde elementos de sabor neoclassicizante no pavimento inferior (aberturas em arco pleno, ordens e estátuas de faiança sobre a platibanda) e, ao alto, no eixo central da fachada, viam-se mirantes achalezados, não raro providos de janelas de arco quebrado, de influência medievalizante. Num jornal de 1881, deparamo-nos com um anúncio referente a leilão de prédio de rendimento, onde, provavelmente, é feita a descrição de um exemplar dessa tipologia: 
69. Cf. UTIL e rendoso emprego de capital.

Útil e rendoso emprego de capital / Novo e bonito predio / Roberto Tavares / Fará / Terça-feira 25 do corrente / Dia Santo / ás 10 1/2 horas em ponto / 2 Rua dos Carmelitas 2 / por conta e ordem de quem pertencer / E mais um terreno ao lado / Este bonito predio recentemente construido / Tem 50 palmos de frente sobre 204 de fundo / Divide-se em dois lanços, em quatro janellas / De frente e porta no centro, com um lindo mirante / em cima. As divisões internas são as seguintes / em cada lanço, a saber: salão de vizitas, duas grandes alcovas, dispensa, e boa cosinha / Seguindo-se quintal, latrinas etc. Tudo plantado / e em perfeito estado; O outro lanço é igual ao primeiro. / O mirante dispõe de 2 quartos e grande terraço gradeado / Sua renda é de 1204000 mensaes / O leilão è [sic] a todo preço / e os srs. negociantes, capitalistas e proprietários não devem perder a / occasião de empregar bem seus capitaes nesta venda que é / urgente e forçada por seu proprietário seguir para a Europa. ${ }^{69}$

Verificamos assim que o imóvel acima descrito era curiosamente constituído de duas residências modestas independentes no pavimento inferior, com acesso comum pela porta central, e de um mirante na cobertura, que dispunha de duas acomodações servidas pelo terraço, aparentemente independentes também. Acreditamos que, nesse caso, não deva ser desprezada a opinião daqueles que vêem nesse tipo peculiar de construção a influência da

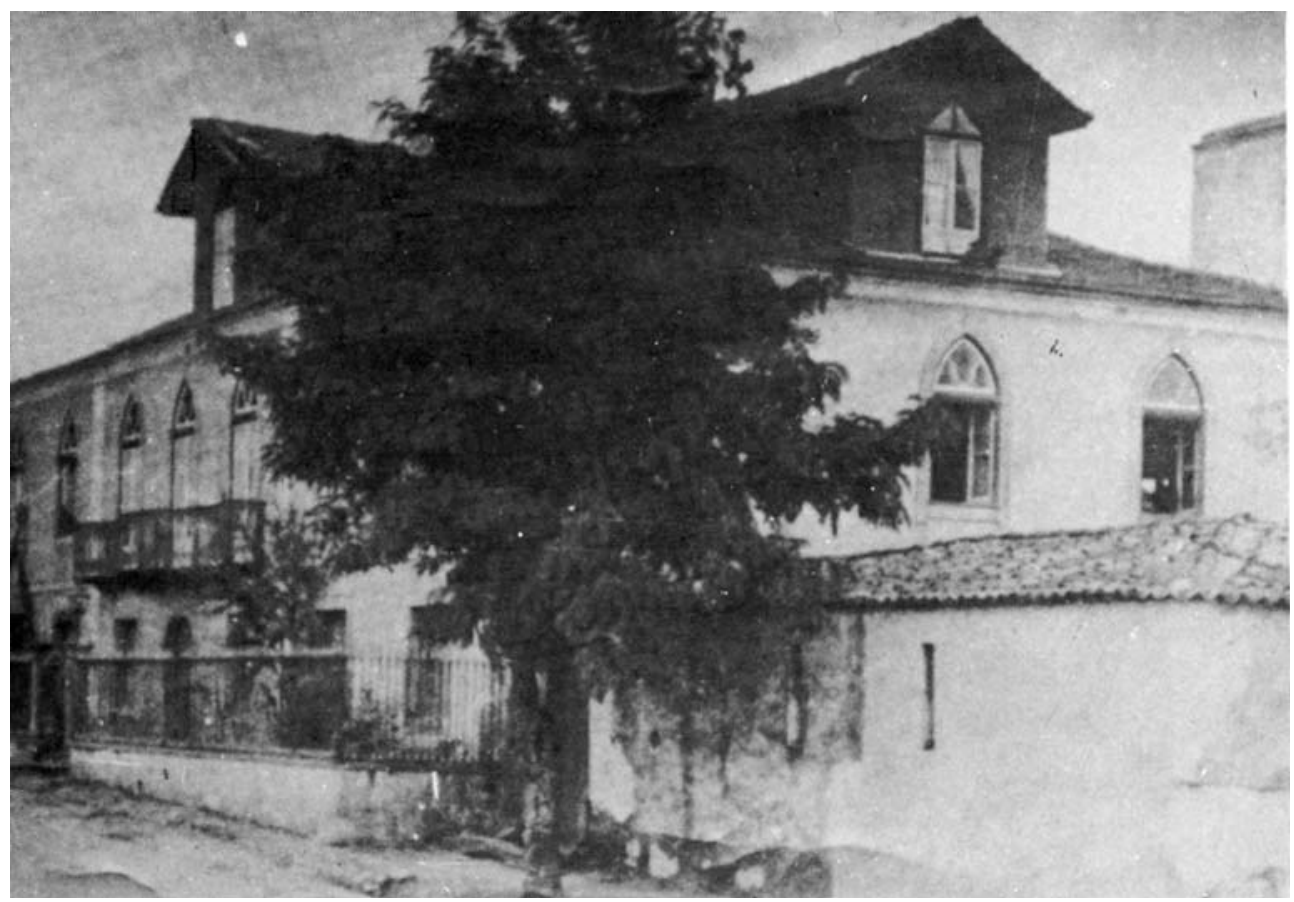

Figura 25 - Sobrados oitocentistas portugueses como esse devem ter dado origem à "casa com torre" açoriana. Por outro lado, é possível que sobrados com águas-furtadas, ou mirantes, em forma de chalé do tipo visto na foto tenham sido construídos no Brasil por mestres-de-obras portugueses vindos diretamente de seu país natal.

Anônimo. Exemplar de sobrado com influência neogótica nas aberturas e águas-furtadas em forma de chalé, situado em Cernache do Bomjardim, distrito de Castelo Branco, Portugal, data desconhecida. Fotografia. Em Selda V. Costa e Narciso J. F. Lobo (1987). 


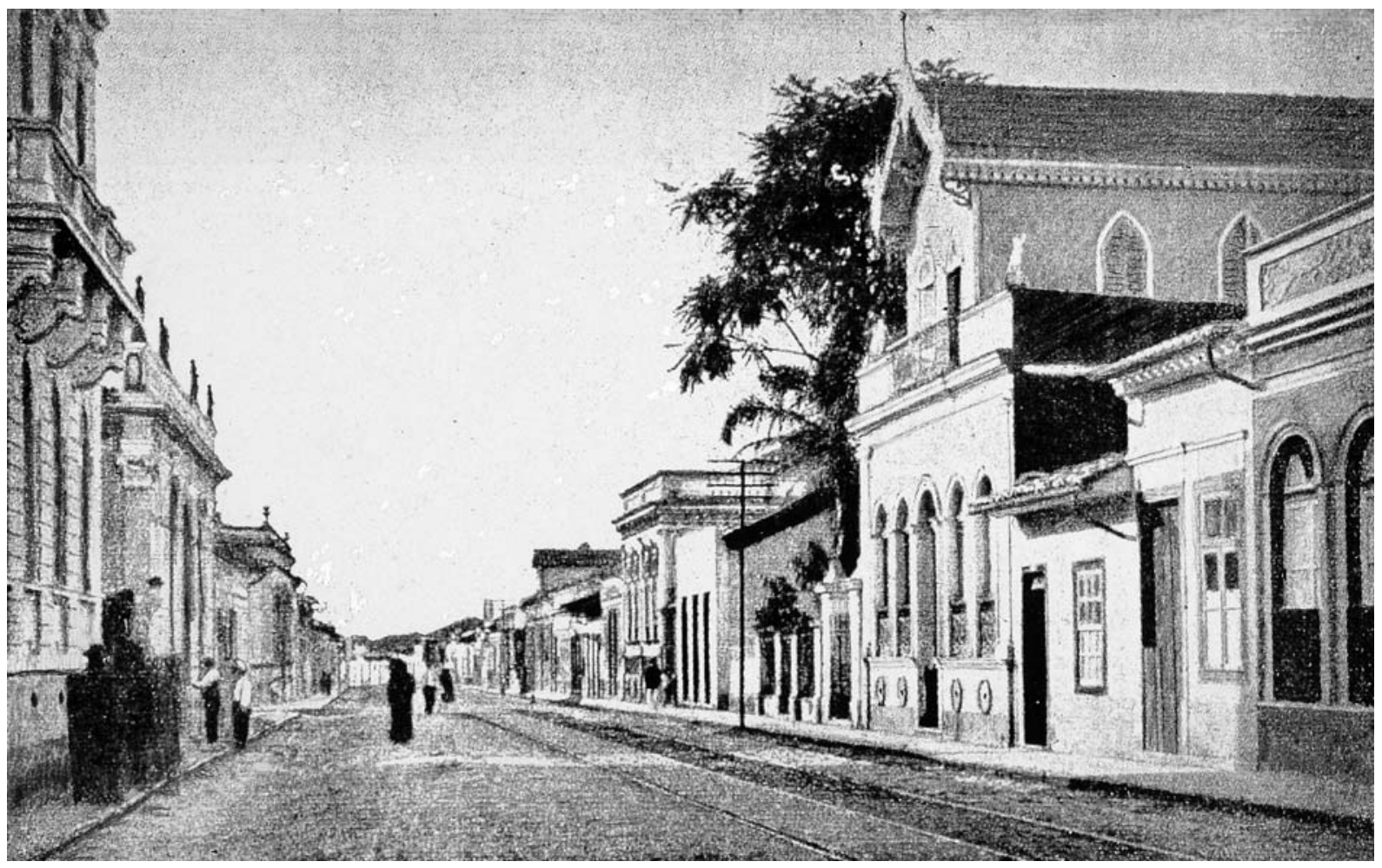

Figura 26 - Na vista da rua Sete de Abril,surpreendemos uma bela edificação que combinava elementos neoclássicos presentes no primeiro pavimento com um mirante achalezado de aparência neogótica na cobertura. Um tipo de construção, ao que parece, influenciado pela "casa com torre" açoriana. Axel Frick. Aspecto da rua Sete de Abril, c. 1895. Fotografia. Em Gustavo Koenigswald (1895). Acervo Biblioteca Mário de Andrade, São Paulo. Reprodução de José Rosael.

impropriamente chamada "casa com torre" açoriana do século XIX, trazida talvez do arquipélago e aqui adaptada por mestres-de-obras de origem lusitana. É possível também que essa tipologia tenha surgido primeiramente em Portugal, pois por meio de fotos antigas conseguimos localizar exemplares semelhantes nesse país (Figura 25).

Vários edifícios paulistanos, hoje observáveis em velhas imagens fotográficas, tinham por coroamento um corpo mais estreito e recuado, coberto com telhado de chalé. Numa foto publicada no álbum São Paulo, de Koenigswald ${ }^{70}$, surpreendemos, na rua Sete de Abril, uma edificação desse tipo que, como de hábito, combinava elementos neoclássicos, presentes no primeiro pavimento assentado sobre porão, com um mirante achalezado de aparência neogótica na cobertura (Figura 26). Na antiga rua da Boa Morte, atual rua do Carmo, não longe da igreja de mesmo nome, também se via um exemplar desse gênero, com o ano de 1885 inscrito na cartela da fachada (Figura 27). Poderíamos citar ainda um outro edifício dessa natureza, erguido entre as ladeiras que conduziam do Centro ao antigo Piques, antigas ruas do Meio (Ladeira do Ouvidor) e de São Francisco (Figura 28). No Arquivo Histórico Municipal
70. Gustavo Koenigswald (1895, p. 65, fig. 47). 


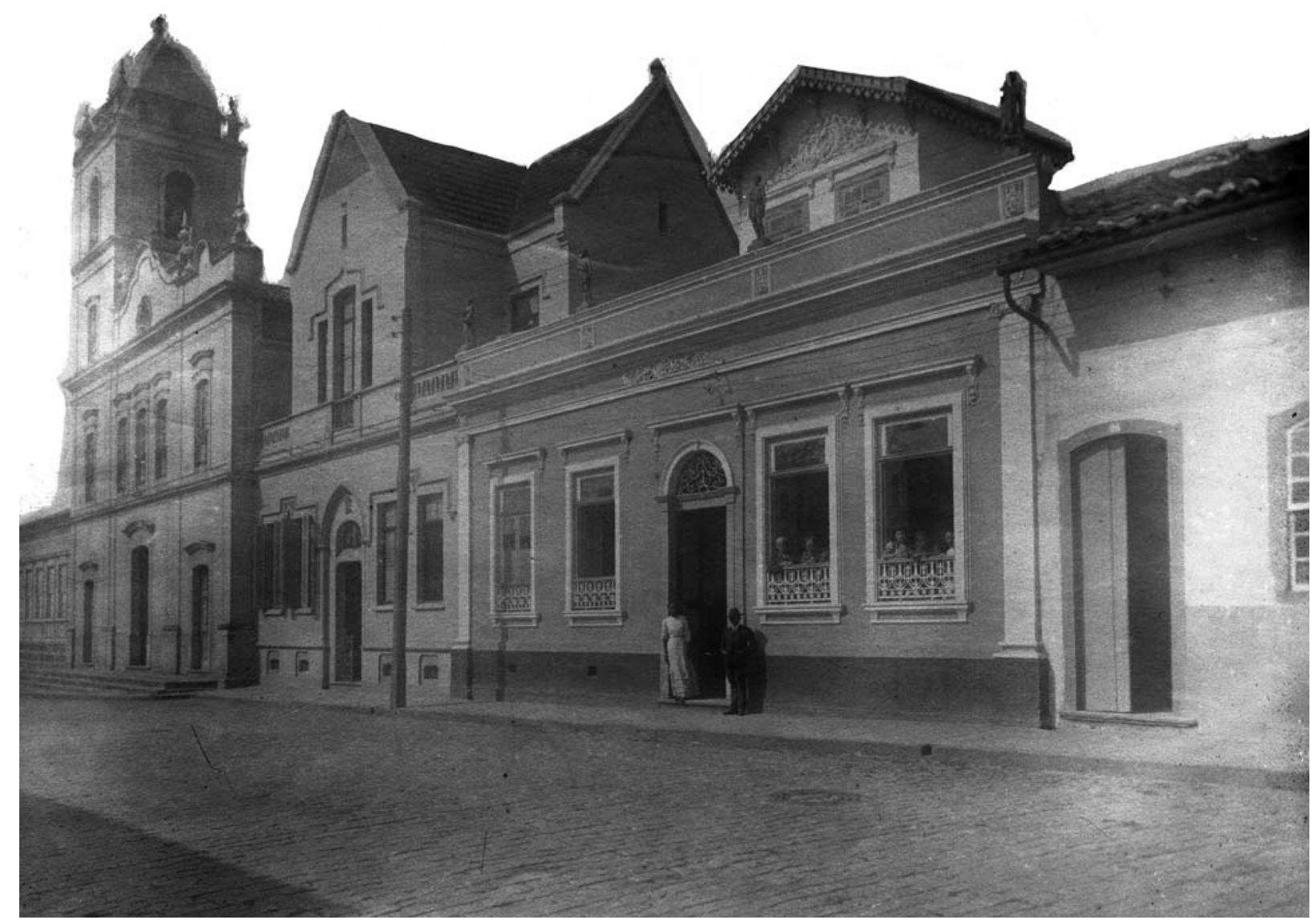

Figura 27 - Anônimo. Vista da rua da Boa Morte, hoje do Carmo, mostrando uma residência de linhas neoclássicas com mirante achalezado, datada de 1885. Fotografia. Início do século XX. Acervo da Divisão de lconografia e Museus, Departamento do Patrimônio Histórico, São Paulo.

71. SÃO PAULO (Cidade) ( $L i$ vros de lançamento, v.0481, folha $3 v$ ).

72. Jorge Americano (1957, p. 180-181).

73. Ver foto correspondente ao negativo n. $500 \mathrm{E}$ do acervo de DIM.

74. Eudes Campos (2005, p. 40). deparamo-nos com um auto de alinhamento lançado em 17 de junho de 1886 referente a essa construção. Foi concedido em nome do famigerado padre Pascoal Gazineu1, um empedernido dono de cortiços retratado com muita vivacidade por Jorge Americano em suas recordações sobre São Paulo daquele tempo ${ }^{72}$. $\bigcirc$ prédio, de mirante com a aparência de chalé, trazia no friso do terceiro pavimento a data de $1887^{73}$. E chegamos a conhecê-lo pessoalmente na infância, pois só foi derrubado no final da década de 1950 para ser substituído por um edifício de vários andares, ainda hoje existente no local. Por fim, não devemos esquecer de duas casas geminadas, com mirantes localizados acima da linha da cimalha, construídas a partir de 1881 pelo português Manuel Ferreira Leal na rua Florêncio de Abreu (Figura 29). Eram contíguas à sua própria residência latual rua Florêncio de Abreu, n. 11 1, hoje mais conhecida como Casa de D. Marieta), e a elas fizemos alusão em outro artigo de nossa autoria publicado nestes Anais ${ }^{74}$. 


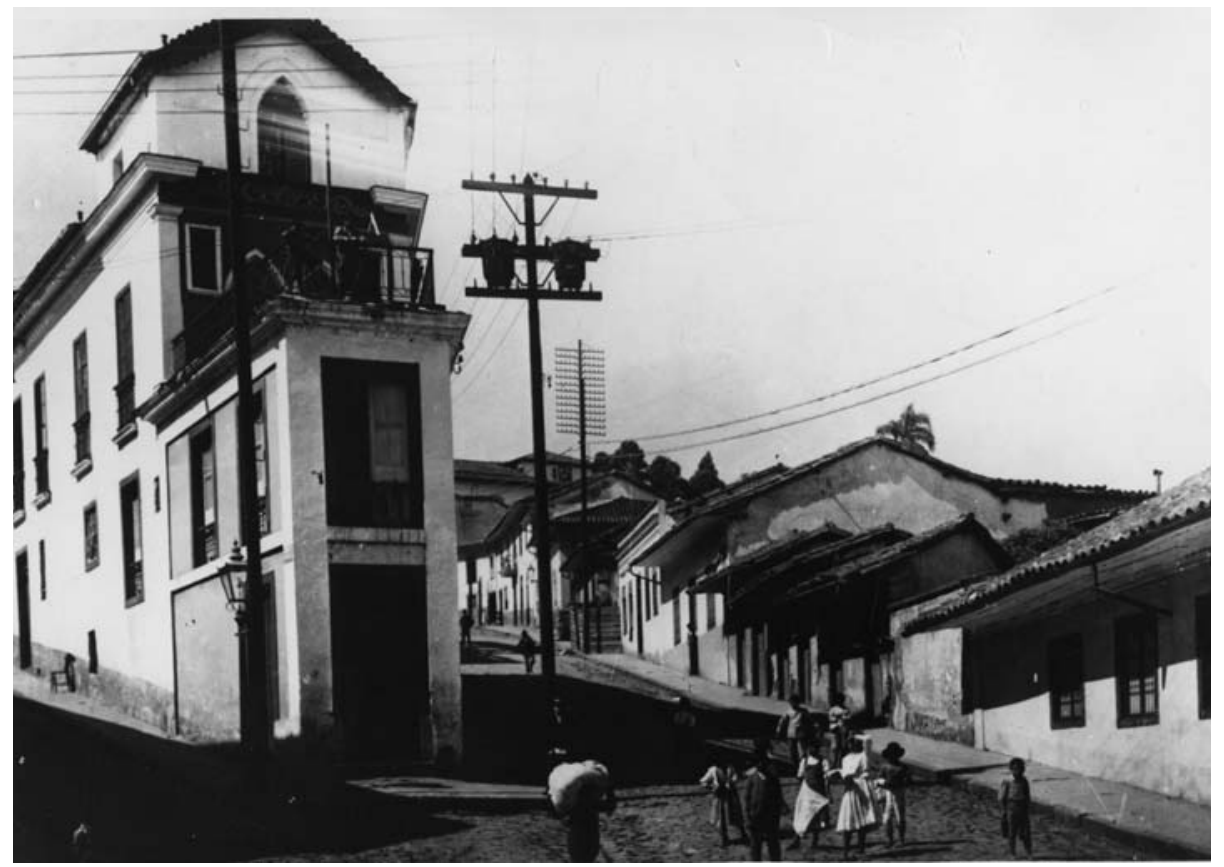

Figura 28 - Prédio pertencente ao padre Pascoal Gazineu, demolido em fins da década de 1950, aproximadamente. Seguia a outrora popular tipologia de edifício provido de sótão, ou mirante, em forma de chalé. Anônimo. Edifício erguido entre 1886 e 1887 entre as ladeiras que conduzem do Centro ao antigo Piques, antigas ruas do Meio e de São Francisco, início do século XX. Fotografia. Acervo da Divisão de lconografia e Museus, Departamento do Patrimônio Histórico, São Paulo.

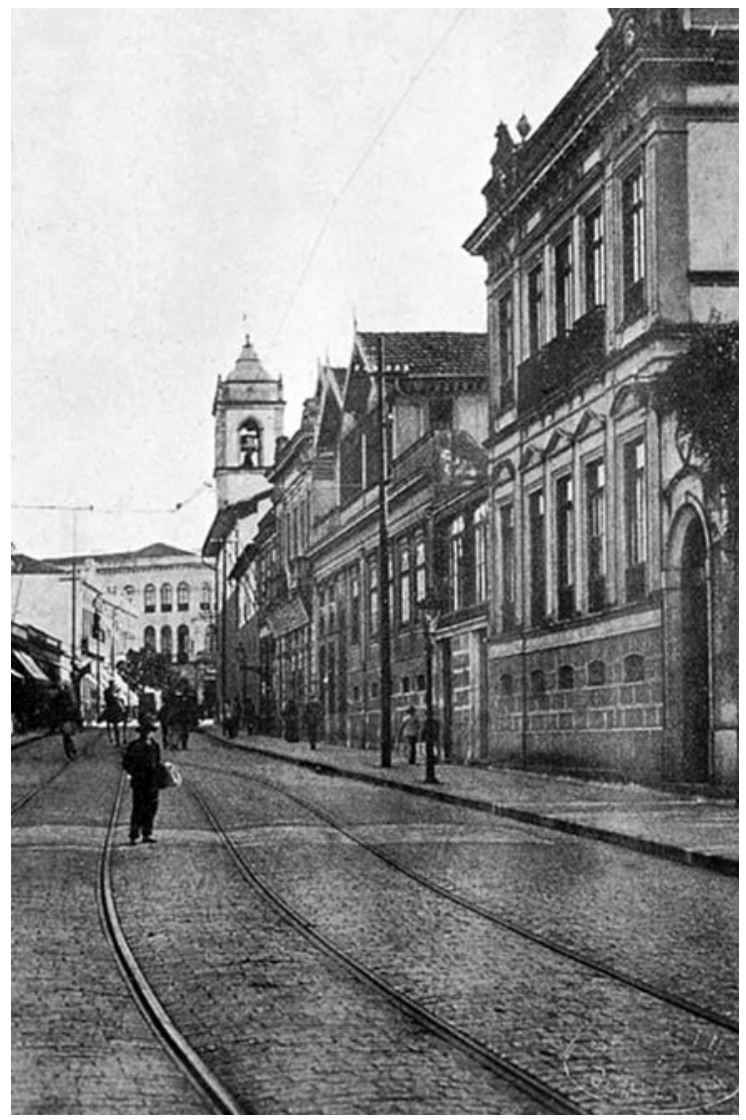

Figura 29 - No detalhe, ao fundo, vêem-se duas casas com mirantes em forma de chalé erguidas pelo português Manuel Ferreira Leal em 1881. Anônimo.Vista da Rua Florêncio de Abreu em direção ao Largo São Bento, início do século XX. Fotografia. Em São Paulo antigo e São Paulo moderno, 1554-1904, [1905]. Acervo Biblioteca da Escola Politécnica da USP, São Paulo. 
75. Lerner\& Bittencourt (2005, p. 82).Ver excelentes imagens desse conjunto denominado CASAS Casadas.

76. SÃO PAULO (Cidade) ( $L i$ vros de lançamento, $\mathbf{v} 0376$, folha 152v).

77. Idem (v. 0480, folha 81v).

78. SÃO PAULO (Cidade) (Obras particulares, v. 128, folha 73 e ss).
Finalmente, sabemos ter existido no centro da cidade um grande e vistoso conjunto de edifícios geminados pontoado por mirantes em forma de chalé (Figuras 30A e 30B). Ocupava grande parte do quarteirão limitado pela rua da Imperatriz ( 15 de Novembro), travessa do Colégio (rua Anchieta) e largos da Sé e do Palácio (pátio do Colégio). Pertencente ao comerciante português Joaquim Lopes Lebre, então visconde de São Joaquim, foi levantado entre o final dos anos de 1870 e o início da década seguinte. Esse correr, decerto, impressionava com a sua sucessão de mirantes achalezados, e na provinciana São Paulo equivalia, de certo modo, ao notável conjunto arquitetônico carioca conhecido como Casas Casadas Igrupamento de seis casas geminadas, das quais quatro com três pisos, e duas, no centro, com quatro e empenas de chalé), sito na rua das Laranjeiras e erguido, entre 1874 e 1885, por iniciativa de Antônio de Oliveira Leite Leal, rico cidadão de origem portuguesa ${ }^{75}$.

Em assentamentos constantes do AHMWL, encontramos o lançamento de auto de alinhamento, efetuado dia 7 de agosto de 1879, concedido ao visconde para erguer um prédio na travessa do Colégio ${ }^{76}$. Tratava-se certamente da construção de uma das unidades pertencentes ao conjunto que aqui nos ocupa. Nesse mesmo tipo de documentação, encontramos um outro auto de

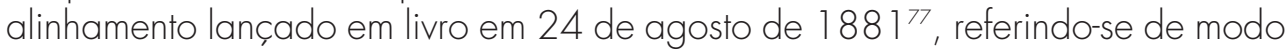
específico à unidade localizada na esquina do largo de Palácio com travessa do Colégio (Figura 31 ).

Em 1896, foi requerida à Intendência autorização para demolir o mirante correspondente ao edifício da rua 15 de Novembro, n. 4 (Figura 32), e substituíto por telhado comum ${ }^{78}$. A obra achava-se sob a responsabilidade do mestre português Manuel dos Reis Pinto da Rocha, provável autor do conjunto, pois sabemos que, desde ao menos os anos de 1880, Rocha trabalhava habitualmente para São Joaquim. $O$ proprietário desses prédios, de origem lusa, como dissemos, habitava, segundo os almanaques da época, justamente no sobrado de n. 4 da rua 15 e tinha no térreo o seu negócio, a famosa Casa Lebre, dedicada ao comércio de ferragens.

A supressão do mirante em forma de chalé da construção de n. 4 estava, sem dúvida, diretamente ligada ao fato de Lebre ter deixado sua casa em 1896 para que fosse ocupada temporariamente pela Câmara de Vereadores, desalojada de sua sede tradicional, no Largo de São Gonçalo. Já no ano seguinte, a Câmara se transferiria para a antigo Palácio do Tesouro Provincial, sito na rua de mesmo nome, prédio, iniciado no tempo do presidente João Teodoro, que adquirira feições neo-renascentistas durante uma grande reforma ocorrida em 1891. Mas pelas convenções arquitetônicas então vigentes, era inadmissível que a sede da municipalidade de uma cidade florescente como São Paulo se instalasse, mesmo que de forma temporária, num imóvel de destinação mista (comercial e residencial). Ainda mais quando adornado com um elemento arquitetônico de aparência trivialmente pitoresca e doméstica, a afrontar a elevada natureza oficial da instituição que logo viria a ocupar o edifício. Além disso, não nos esqueçamos que o edifício em questão se situava no início da rua 15 de Novembro, dentro do Triângulo portanto, e que, por sua 

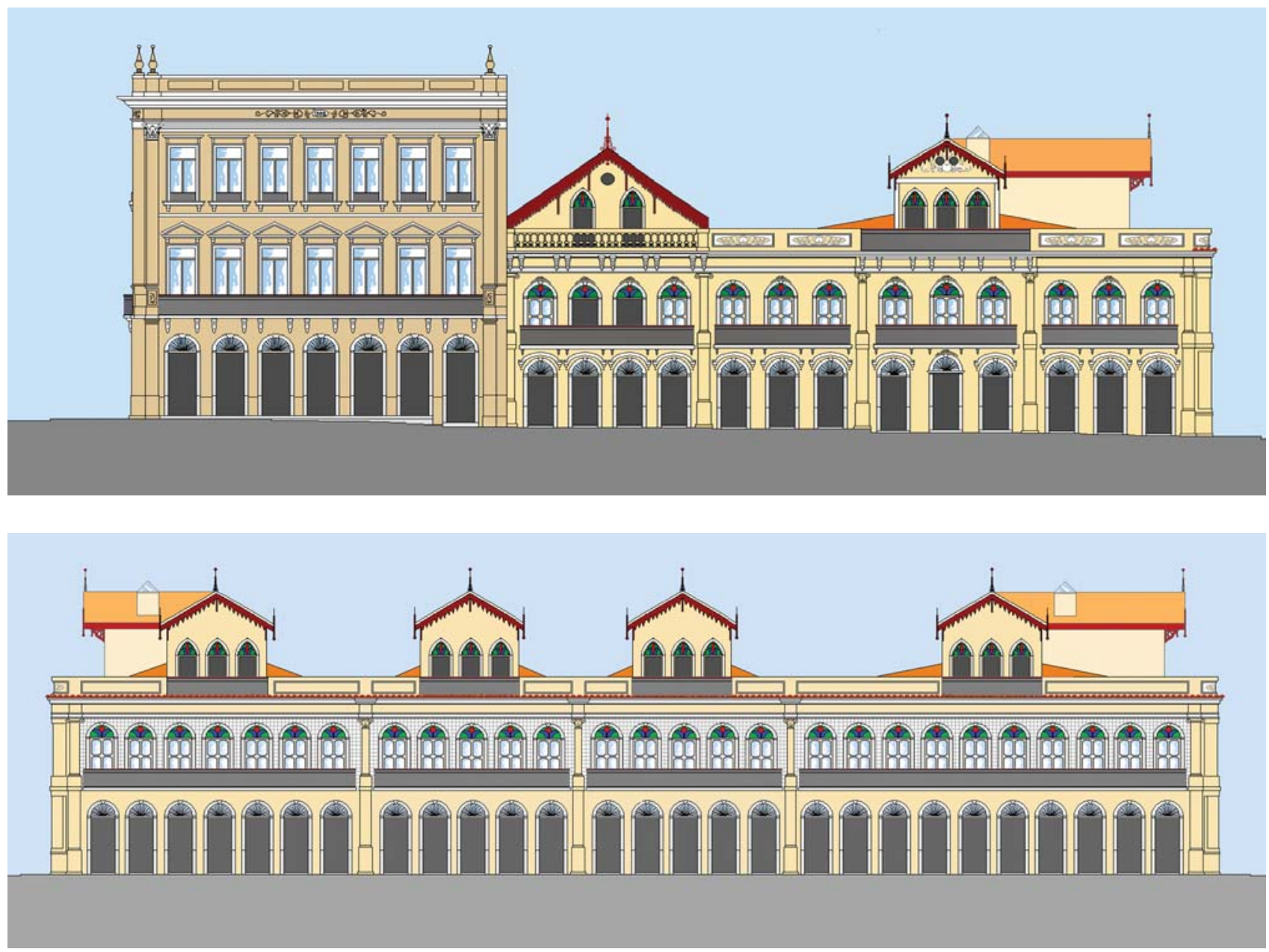

Figuras 30A e 30B- Na reconstituição do conjunto arquitetônico pertencente ao conde de São Joaquim servimo-nos de antigas imagens fotográficas (c. 1894, c. 1906 e c. 1930), fotos aéreas provenientes do século XX (c. 1925 e 1954) e plantas cadastrais, datadas dos séculos XIX e XX (1882 e 1930). Na face de quadra dando para o largo de Palácio (hoje pátio do Colégio), vemos a partir da esquerda, o edifício de três andares até hoje existente na esquina da praça da Sé, datado de 1888, um sobrado com grande telhado de chalé e balaustrada de cimento no balcão acima da cimalha e o bloco com mirantes achalezados, erguido a partir de 1881 . Na face que deita para a travessa do Colégio (atual rua Anchieta), os edifícios mostravam-se bem menos ornamentados, em razão da pouca importância que tinha a via pública em que se situavam, quase um beco. As fachadas do primeiro andar estavam revestidas de azulejos e o conjunto destacava-se pela seqüência de quatro mirantes em forma de chalé, postados um ao lado do outro. Vemos a partir da esquerda, o bloco erguido em 1881, cuja fachada principal olhava para o largo de Palácio; o sobrado de $n^{\circ}$. 40, que subsistiu ao menos, até fins dos anos de 1950; um sobrado de configuração hipotética, e o bloco, talvez o mais antigo do conjunto, onde morava o conde de São Joaquim, na esquina da rua 15 de Novembro. Na cobertura dos chalés havia um curioso elemento arquitetônico que nos pareceu ser um lanternim. Eudes Campos. Proposta de reconstrução gráfica aproximada do extenso conjunto de prédios pertencente ao conde de São Joaquim (erguido entre o final da década de 1870 e 1888), localizado nas faces de quadra voltadas para o velho largo de Palácio (fig. 31 A), e para a velha travessa do Colégio (fig. 31B), respectivamente. Desenho executado com técnica digital. 


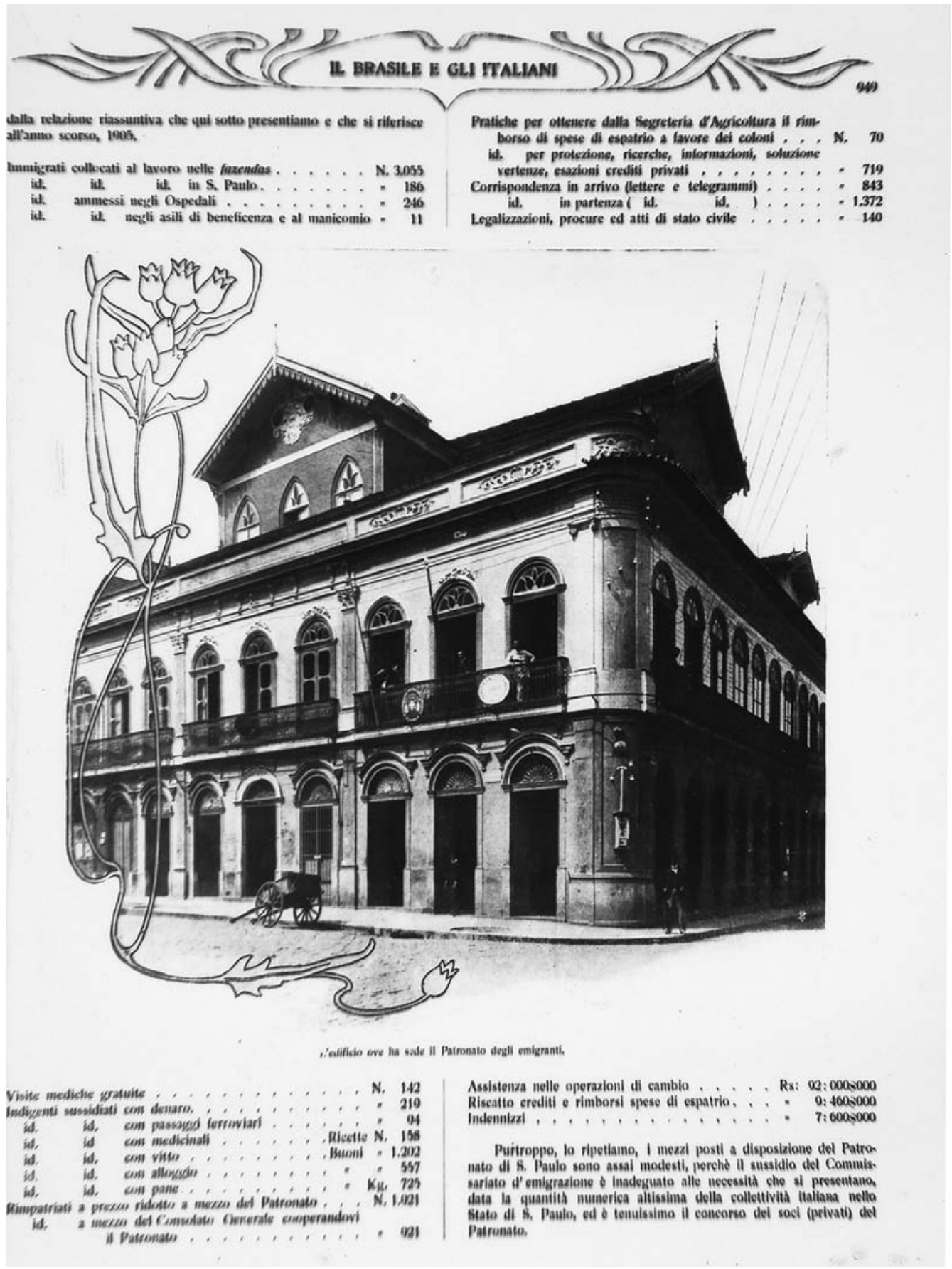

Figura 31 - Extenso conjunto de edifícios, providos de mirantes em forma de chalé. Pertencente ao conde de São Joaquim, foi construído entre o final dos anos de 1870 e começos da década seguinte, provavelmente pelo mestre-de-obras português Manuel dos Reis Pinto da Rocha, que trabalhava habitualmente para o conde.Anônimo. Grande conjunto de edifícios construído entre a rua da Imperatriz latual 15 de Novembro), travessa do Colégio (Anchieta) e largo do Palácio (pátio do Colégio), c. 1906. Fotografia. Em Il Brasile e gli italiani, [1 907]. Acervo da Biblioteca Municipal Mário de Andrade, São Paulo. 


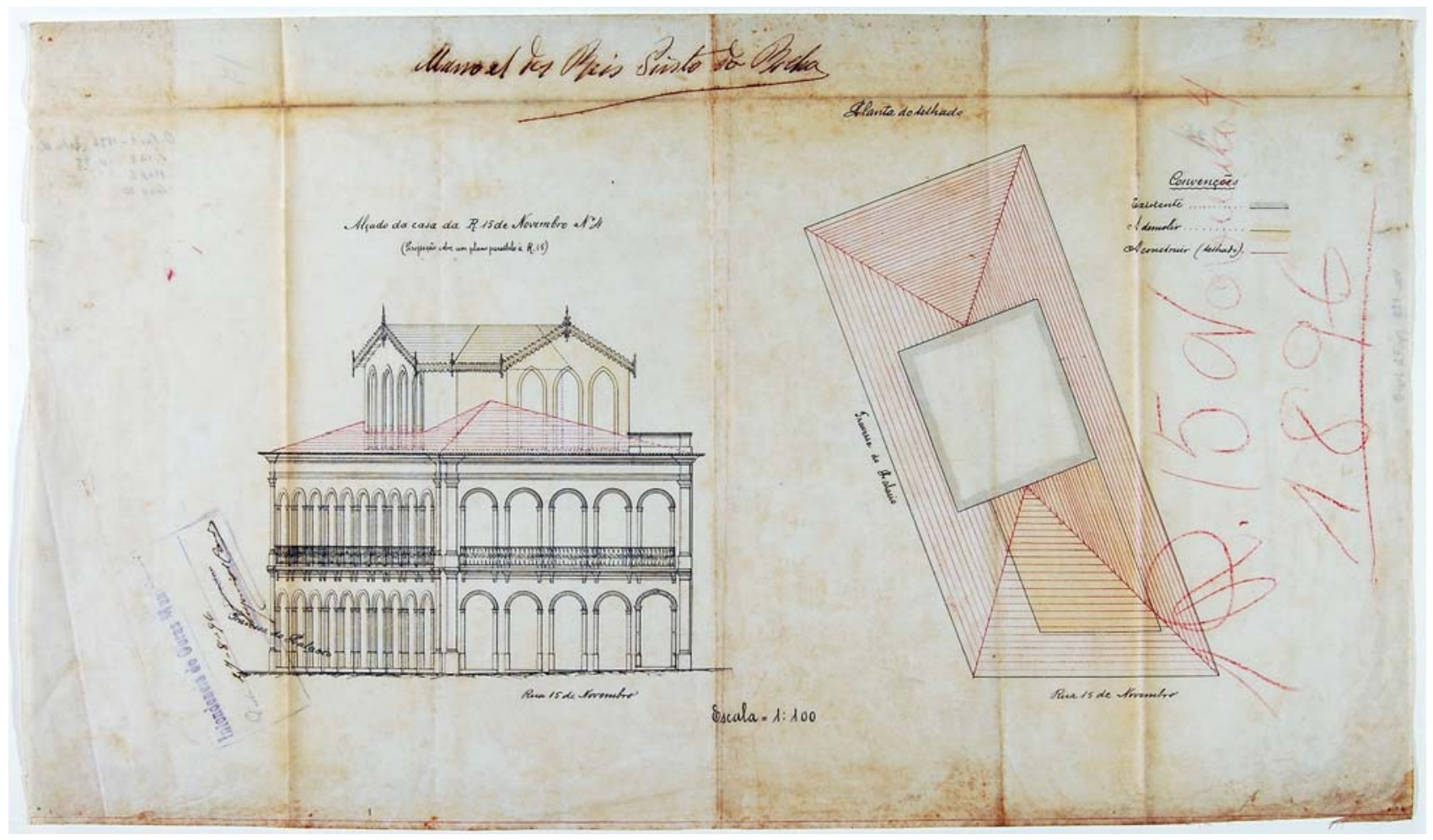

Figura 32 - Em 1896, requereu-se à Intendência autorização para demolir o mirante correspondente ao edifício da rua 15 de Novembro, n. 4, uma das unidades do conjunto pertencente ao conde de São Joaquim. Pretendia-se construir, no lugar da parte demolida, um telhado comum. A obra achava-se sob a responsabilidade do mestre português Manuel dos Reis Pinto da Rocha, provável autor do conjunto, e a reforma deve ter sido motivada pela iminente mudança da Câmara dos Vereadores para o imóvel. Não ficava bem a sede da administração municipal abrigar-se numa construção de destinação mista e aparência pitoresca. Anônimo. Perspectiva e planta da cobertura do imóvel da rua 15 de Novembro, nº 4, 1896. Desenho técnico. Acervo do Arquivo Histórico Municipal (AHMWL), São Paulo. Reprodução de José Rosael.

localização, estava em desacordo com o padrão municipal em vigor, como vimos algumas páginas atrás.

Fora do Triângulo, porém - de fato bem longe dele, no bairro de Vila Buarque, que então começava a ser ocupado -, conseguimos identificar um outro exemplar de sobrado com mirantes em forma de chalé, em lote de esquina sito na rua Bento Freitas com a Rego Freitas, a poucos metros de distância do prédio com empenas lambrequinadas a que aludimos na nota 64 deste artigo, por sua vez situado na esquina da Rego Freitas com a General Jardim. Tratava-se de sobrado de mirantes achalezados de construção iniciada certamente nos últimos dias do Império, já trazendo nas fachadas uma decoração sobrecarregada, que caracterizaria as edificações erguidas nos anos de 1890. (O edifício vizinho também exibia estilo decorativo semelhante.) A imagem dele que chegou às nossas mãos é proveniente de um anúncio saído na imprensa diária paulistana no dia 30 de dezembro de $1891^{79}$. Segundo o reclame publicado, no n. 8 da rua Bento Freitas estava instalada a casa de saúde dos Drs. Artur Azevedo, Melo
79. Ver CASA de Saude. Uma vez mais agradecemos à gentileza da pesquisadora Maria Lucia Mott, que nos indicou o anúncio em questão, contendo a imagem deste relevante exemplar. 
Barreto e João Teixeira - conhecida como Casa de Saúde São José -, pronta para o recebimento de doentes de moléstias "medicas e cirurgicas", com seção apropriada para parturientes, bem montados aparelhos de duchas terapêuticas e acomodações especiais para alienados, em edifício separado.

Acima do nível da cimalha, os mirantes, um em cada face, unidos pela parte posterior, formavam uma cruz, e no ponto de união elevava-se um torreão de remate, adornado com uma grimpa. A decoração de madeira lavrada que guarnecia as empenas se mostrava exuberante e os pináculos exibiam-se devidamente torneados (Figura 33).

Figura 33 - A. Krüger. Casa de Saúde São José, localizada na esquina da rua Bento Freitas com a rua Rego Freitas. Litografia em anúncio. Publicada no Diário Popular, de 30 de dezembro de 1891. Acervo da Biblioteca Mário de Andrade, São Paulo.

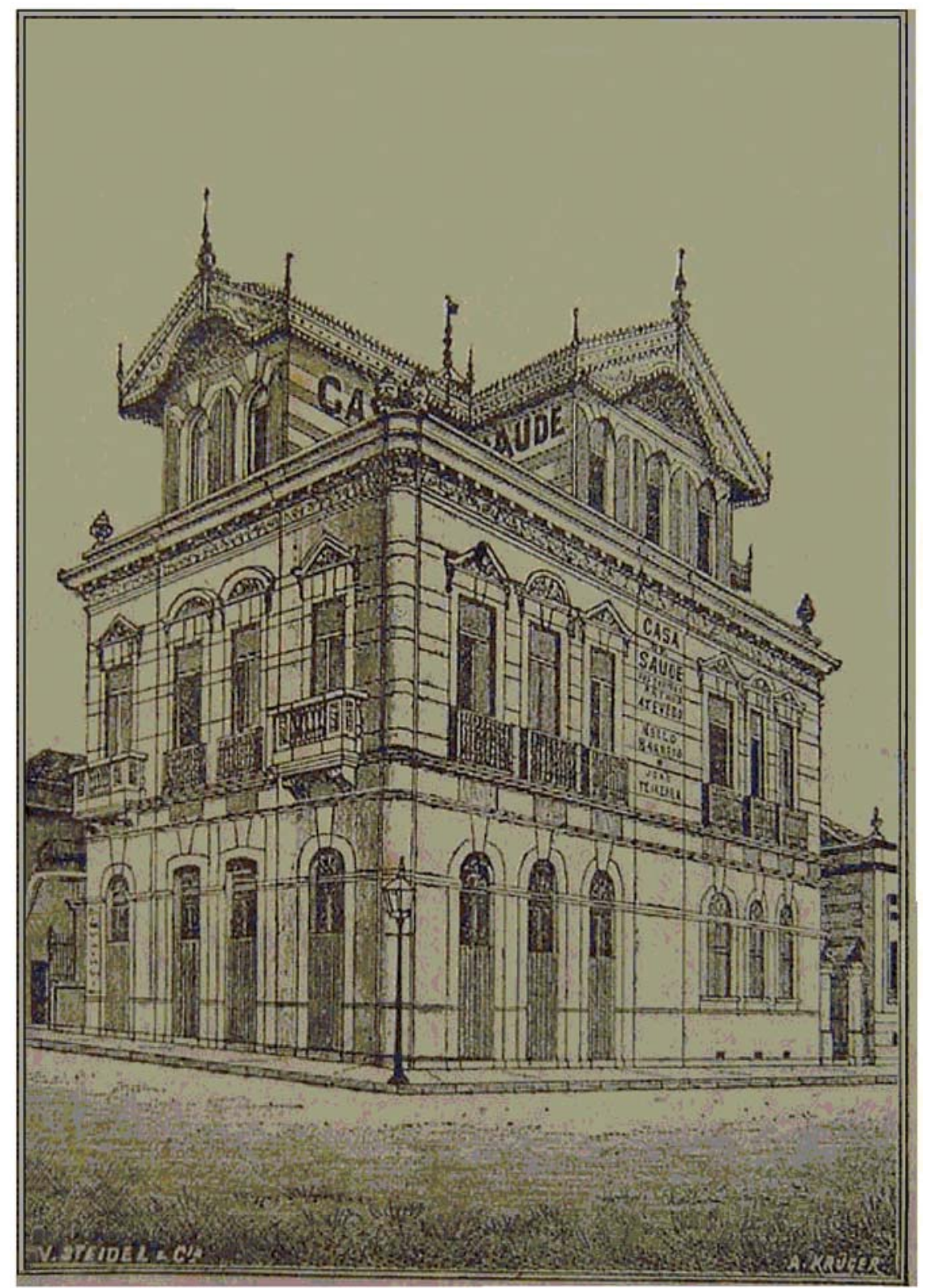


Ao que tudo indica, remonta aos fins do Oitocentismo o início da fase 81. Eudes Campos (2005,fig. $15)$. declinante dos chalés, ao menos daqueles erguidos nas proximidades do Centro paulistano. Na obra intitulada São Paulo em três tempos, há uma fotografia interessante ${ }^{80}$, que parece confirmar nossas suspeitas; data de 1914 e pertence à série de fotografias tomadas de diferentes pontos da Capital por Aurélio Becherini, em acatamento à ordem do prefeito Washington Luís, que decidiu mandar executá-las para servir de contraponto atualizado ao álbum comparativo lançado por Militão de Azevedo em 1887. A foto em questão registra a rua Brigadeiro Tobias a partir da esquina da rua Senador Queirós, em direção ao bairro da Luz. À esquerda, deparamos-nos com o antigo sobrado do conde de Três Rios, a que fizemos referência. A velha construção, que se tornara a moradia paulistana do conde do Pinhal, fora modernizada; a empena, com seus lambrequins e outros enfeites de madeira lavrada, havia sido removida e no lugar viam-se agora meras platibandas de tijolos; quanto ao extenso balcão de madeira fronteiro, também desaparecera, substituído por outro, pequeno, feito de alvenaria. $\bigcirc$ pedestre desavisado que por aí passasse jamais iria supor que a construção localizada na esquina tivera algum dia a aparência de chalé, e esse era justamente o objetivo da intervenção arquitetônica então levada a cabo ${ }^{81}$.

$\bigcirc$ declínio do chalé em São Paulo talvez não deva ser interpretado como um mero fenômeno de natureza estética. Por detrás desse fenômeno, é quase certo que se esconda outro, de natureza social. Na verdade, o padrão de 1889 não tentara erradicar o chalé; apenas almejara disciplinar sua ocorrência dentro dos limites da cidade, já que a presença de uma construção de caráter essencialmente suburbano em ponto central e "nobre" ofendia as convenções arquitetônicas acadêmicas então vigentes. Do ponto de vista das camadas hegemônicas, das quais emanavam tais convenções, era inaceitável que edifícios modestos tentassem atrair a atenção sobre si de modo tão equivocado, isso ocorrendo numa cidade que procurava modernizar-se, aproximando-se dos padrões arquitetônicos e urbanísticos internacionais. Sob esse aspecto, São Paulo estava à frente da própria Capital Federal, que só em fevereiro de 1903 (Decreto n. ${ }^{\circ} 391$ ) conseguiu fazer aprovar uma norma edilícia equivalente ${ }^{82}$.

Em contrapartida, diferentemente do que ocorreu no Rio de Janeiro, parece que na imprensa paulistana não se elevou nenhuma voz em campanha explícita contra os chalés, tal como o fez o jornalista e poeta Olavo Bilac (186519181 . Numa crônica de 1904, Bilac ironizou o mau gosto dos "chalés suíços", "dos sotãozinhos em cocoruto" e dos "telhados em bico" ${ }^{83}$. Um ano antes, seu azedume contra as construções dos mestres-de-obras de seu tempo levara-o a invectivar as famosas compoteiras de cimento dispostas no alto das platibandas das casas ecléticas de classe média ${ }^{84}$. Essa aversão aos chalés, aos mirantes achalezados e às compoteiras denunciava o incômodo que as camadas mais altas da sociedade carioca sentiam diante da presença maciça de imigrantes 
85. Idem (p. 40, n. 11).

86. Quando se estuda o chalé, seja no Rio de Janeiro, seja em São Paulo, é certo encontrarem-se, cedo ou tarde, elementos da colônia portuguesa envolvidos na questão, tanto na condição de construtores, quanto na qualidade de encomendantes. Muito provavelmente, os chalés, ou antes, as construções com águas-furtadas (ou mirantes) cobertas com telhados de chalé, fizeram muito sucesso em Portugal durante a segunda metade do século XIX.Daí teriam sido trazidas para o Brasil e levadas para outros centros do mundo lusitano, como o arquipélago dos Açores. Dos Açores também teriam vindo mestres-de-obras para o Brasil, os quais poderiam ter introduzido mirantes com telhados achalezados tanto no Rio, quanto em São Paulo. Infelizmente, não nos foi possível aprofundar aspectos tão relevantes, por não termos encontrado fontes seguras concernentes à matéria aqui tratada. Esperamos que pesquisadores interessados consigam aclarar em definitivo o que neste artigo fica, a contragosto, em estado de meros indícios e suspeitas.

87. Dados retirados de um trabalho de nossa autoria elaborado no AHMWL:SÃO PAULO (Cidade). AHMWL. São Paulo em reconstrução; o centro da cidade entre 1899 e 1914. São Paulo: 2003.(Inédito) lusitanos na Capital Federal e de suas manifestações arquitetônicas, tão distantes do bom gosto das elites.

Para explicar a destruição dos quiosques cariocas, um tipo de mobiliário urbano com afinidades formais com o chalé, Giovanna Rosso del Brenna chegou a evocar uma onda de antilusitanismo cultural e étnico que teria varrido a capital do Brasil na época das grandes transformações urbanas ${ }^{85}$. Isso teria acontecido no Rio porque os portugueses se achavam intimamente envolvidos com quiosques e chalés, por conta do fato de serem, quase sempre, comerciantes, construtores ou proprietários de imóveis de aluguel. Na verdade, tanto na Capital Federal, quanto na capital paulista, muitos dos donos de prédios com cobertura de chalés eram dessa nacionalidade, assim como muitos dos mestres-de-obras que os construíam, sendo, via de regra, tanto uns como outros, de origem social humilde $^{86}$. Desconhecemos se a onda de intolerância suscitada no Rio teve repercussões em São Paulo. Talvez nesta última cidade tenha ocorrido de maneira mais velada e ainda não detectada em nossas pesquisas. Se essa hipótese vier um dia a se confirmar, tal fato não nos causará surpresa, pois, numa sociedade como a da Primeira República, fortemente hierarquizada, intolerante e excludente, os imigrantes, negros e pobres em geral constituíam os principais alvos sociais da desconfiança e do desagrado das camadas hegemônicas, sempre dispostas a colocá-los em seu devido lugar.

Seja como for, o que podemos garantir é que o resultado estético atingido no Centro da capital paulista foi equivalente ao da Capital Federal. As reformas urbanísticas conduzidas durante as gestões dos prefeitos Antônio Prado (1899-1911) e Raimundo Duprat (1911-1914) deram-se de modo a assegurar os interesses fundiários e os critérios estéticos das camadas hegemônicas. $\bigcirc$ realinhamento e o alargamento de várias ruas centrais serviram para criar um novo cenário urbano. Ao mesmo tempo que preparavam a área central da cidade para o transporte urbano motorizado, o bonde, iam eliminando as construções mais indesejáveis quer do ponto de vista formal, quer do ponto de vista social e fundiário, sendo substituídas essas construções por edificações modernas, com fachadas aprovadas pela Prefeitura.

Esse foi o caso, por exemplo, de dois humildes chalés que existiam na rua do Rosário, na região a ser ocupada pela praça Antônio Prado (19021908) (Figura 34). Ambos acabaram derrubados e, em seu lugar, ergueu-se o Palacete João Brícola (1906-1908), resultado de um acordo celebrado entre o proprietário dos imóveis e a Prefeitura (Lei n. ${ }^{\circ} 917$, de 9 de junho de 1906), interessada em ter, no local, construções de qualidade, à altura do novo logradouro. Notemos que a praça Antônio Prado foi a primeira praça moderna da cidade, inteiramente dedicada a atividades terciárias - com prédios de escritórios e comércio a toda volta. Além disso, foi totalmente secularizada, sem a presença de edifício de natureza religiosa como até então era costume em São Paulo, pois durante as obras de remanejamento viário, a igreja do Rosário dos Pretos fora derrubada e reerguida em lugar mais afastado ${ }^{87}$.

Acreditamos ser de interesse recapitular aqui a forma como se deu o desaparecimento de alguns dos mais conhecidos chalés paulistanos localizados 


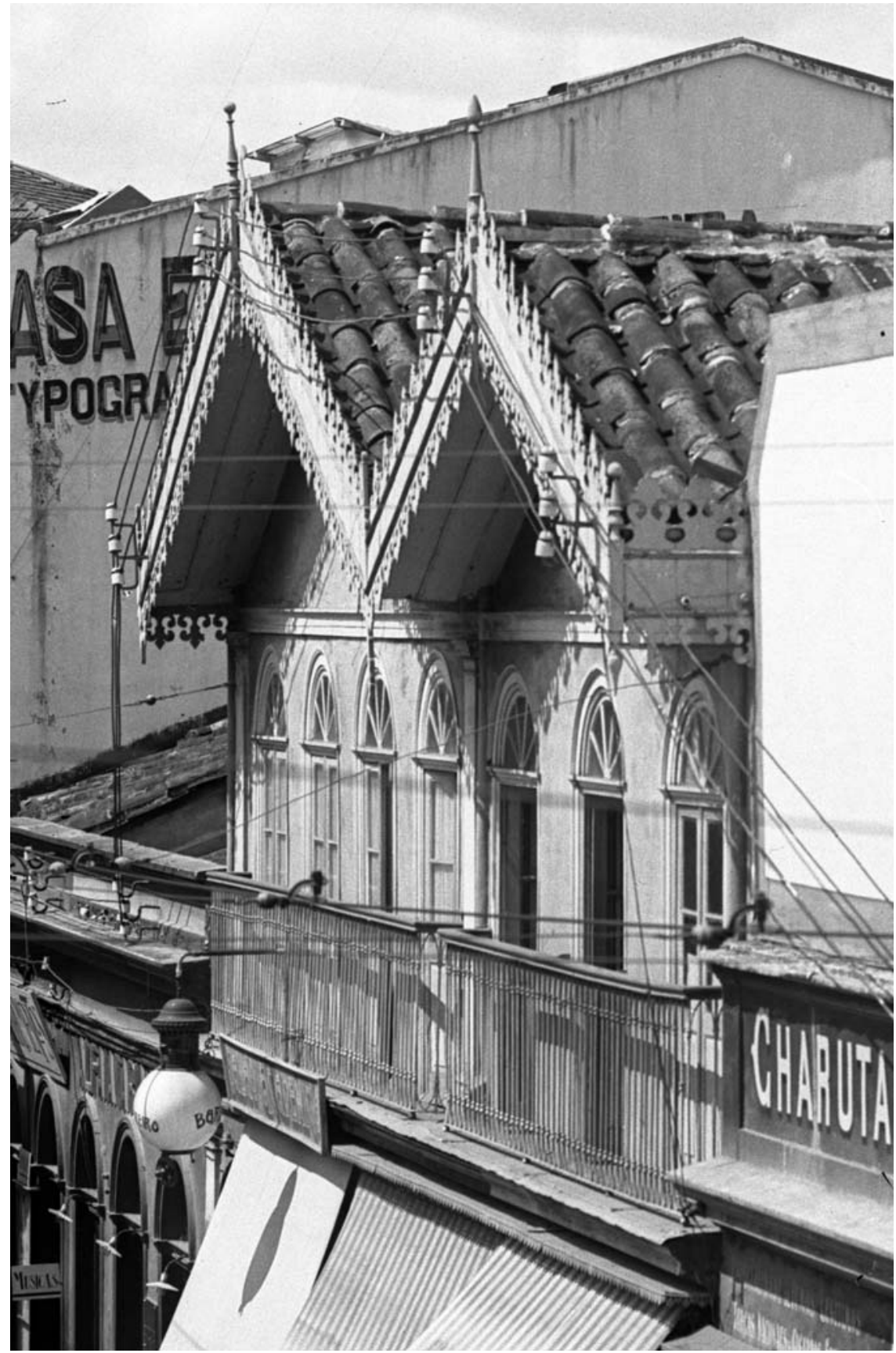

Figura 34 - Os humildes chalés vistos aqui foram demolidos e, em seu lugar, ergueu-se o palacete João Brícola, fruto de um contrato celebrado em 1906 entre a Prefeitura e o proprietário dos terrenos, o sr. João Brícola. Projetada e construída pelo engenheiro Samuel das Neves, a nova edificação estava, na ótica dos contemporâneos, à altura de seu novo endereço, a moderna praça Antônio Prado. Anônimo. Detalhe da vista da rua do Rosário (atual João Brícola), 1904. Fotografia. Acervo da Divisão de Iconografia e Museus, Departamento do Patrimônio Histórico, São Paulo. 
88. SÃO PAUlO(Cidade). AHMWL.VII.A. 142.VII-C-1C (elevação).

89.Anita Salmoni e Emma Debenedetti (1981,p.31,fig. 12).

90. Ver, por exemplo: SÃO PAULO (Cidade) (Obras particulares, v. 334, folha 146 e ss).

91. Ver, por exemplo: SÃO PAULO (Cidade) (VII.A.43; VII.A.9; v.362, folha 163 e ss).

92.Ver,por exemplo:SÃO PAULO (Cidade) (Obras Particulares, v. 362, folha 162 e ss). nas cercanias do Centro. O de Abílio A. S. Marques, por exemplo, erguido junto do vale do Anhangabaú, foi demolido na década de 1890, quando o capitalista e fazendeiro José Estanislau do Amaral, pai da pintora Tarsila, decidiu levantar no terreno do chalé um grande edifício destinado a armazéns e restaurante (1892), de autoria do arquiteto Oscar Kleinschmidt. Esse projeto foi depois substituído por outro, de aparência francesa e destinado a hotel (1894), de autoria do mesmo profissional ${ }^{88}$. A obra ficou paralisada durante anos e, quando foi retomada pelo arquiteto sueco Carlos Ekman (1866-1940) em 1909, converteu-se no Teatro São José, por sua vez demolido para a construção do edifício Alexander Mackenzie (1925-1929), que até hoje se conserva, transformado no Shopping Light. Próximas ao chalé de Abílio Marques, as construções de aparência rural pertencentes à chácara do coronel Proost Rodovalho, no morro do Chá, deram lugar às obras do futuro Teatro Municipal (1903-1911).

Quanto ao chalé de Fernando de Albuquerque, sobreviveu durante várias décadas na Bela Vista, mas depois também desapareceu. Desde os meados do século XX, o terreno está ocupado pelo Edifício Viadutos (1955), de autoria do construtor autodidata João Artacho Jurado. Durante os anos 1950, nas proximidades da área central, só dois edifícios com mirantes cobertos com telhado de chalé subsistiam. $O$ do padre Gazineu, que, como dissemos antes, foi derrubado ainda nessa mesma década, e um outro, sito na rua Anchieta, $n$. 40, cuja imagem foi incluída no estudo que, também naquele tempo, Anita Salmoni e Emma Debenedetti desenvolveram sobre a arquitetura italiana em São Paulo ${ }^{89}$. Constituía esse exemplar o único prédio sobrevivente do conjunto erguido entre os anos 1870 e 1880 pelo então visconde de São Joaquim e deve ter sido destruído algum tempo depois de fotografado, existindo atualmente no lugar uma construção ordinária, sem nenhum interesse.

Entre os anos de 1890 e 1910, aproximadamente, era ainda possível encontrar, com facilidade, pequenos chalés em bairros afastados. Projetados de acordo com a configuração considerada modelar (planta retangular e telhado de duas águas, ornadas com testeiras rendilhadas e pináculos), destinavam-se, em geral, a casas de classe média ${ }^{90}$ (Figura 35) e até mesmo a casas de operários $^{91}$ (Figuras 36 e 37). Pelo que se vê, a ampla aceitação do chalé acabou por contribuir seriamente para o crescente desprestígio social desse tipo de edificação e, também, de seus elementos arquitetônicos constituintes.

Na arquitetura doméstica erudita da época, continuava a ser empregada, eventualmente, uma ou outra empena inspirada nos velhos telhados suíços, mas agora o efeito estético era muito diferente do de tempos atrás. Os exemplares residenciais das camadas superiores, mesmo quando denominados chalets, resultavam de composições assimétricas muito elaboradas, com coberturas movimentadas, formadas com diversas águas e rincões, e fachadas decoradas segundo o gosto pesado típico do período finissecular ou, poucos anos depois, já influenciadas pelo estilo Secessão $0^{92}$. Nas residências ricas, uma ocasional empena sobrecarregada de ornatos de madeira (entre os quais já não se viam lambrequins, desde então olhados com desdém) limitava-se a coroar 


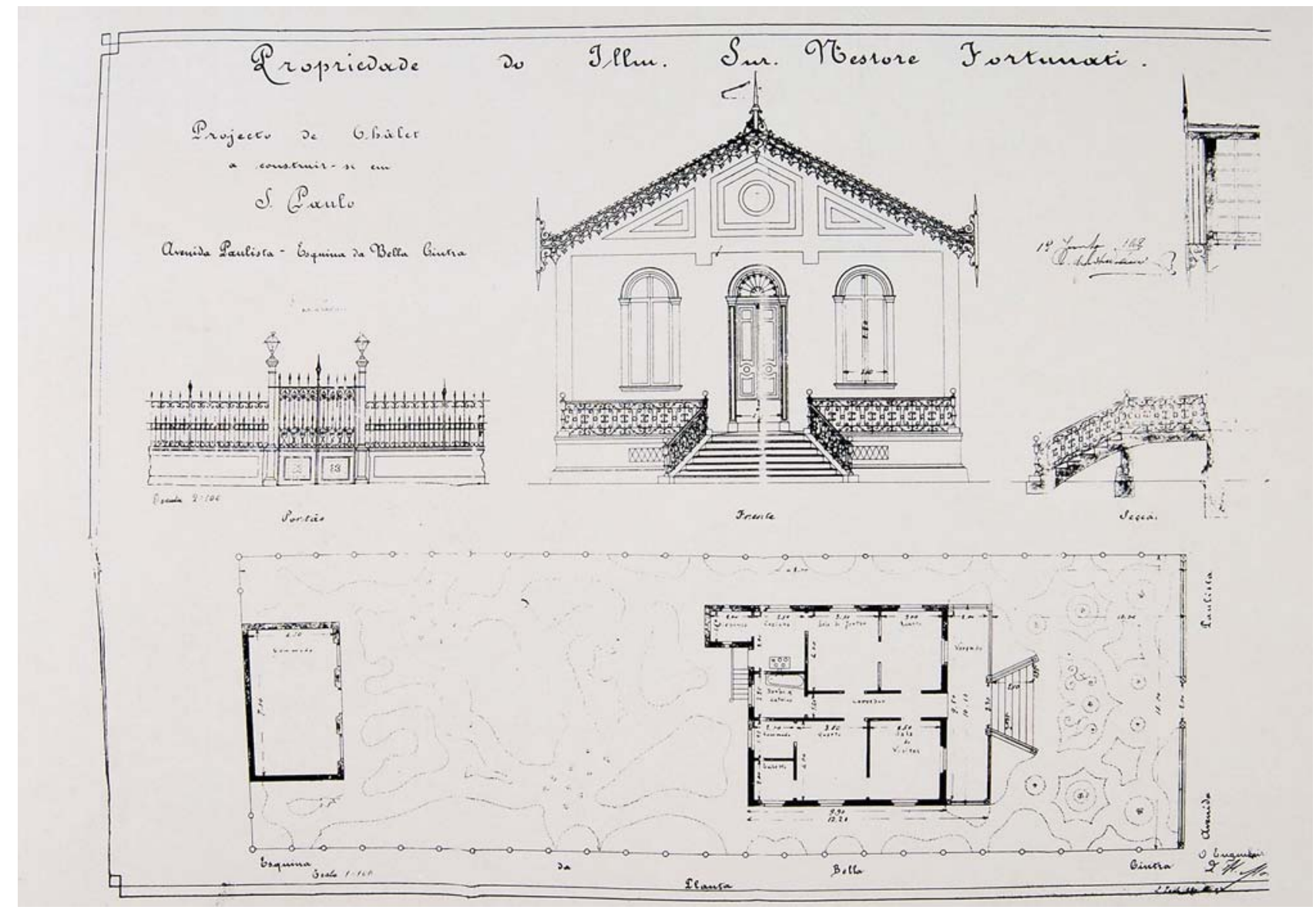

Figura 35 - Notável exemplar de chalé, embora tardio. Trata-se de planta aprovada para uma construção com a conformação típica - "em forma de casota de cachorro", conforme a expressão derrisória de Ricardo Severo -, com uso residencial unifamiliar e localização suburbana. Isolado em meio a jardins, seria erguido num lote da esquina da avenida Paulista com a rua Bela Cintra, em terreno hoje ocupado pela igreja de São Luís Gonzaga. Datava de 1902, e seu projeto, bastante conservador do ponto de vista estilístico, foi concebido por Ugo Moschini, um engenheiro de origem italiana. Destinava-se a família de classe média (ca. $120 \mathrm{~m}^{2}$ de área) e foi concebido numa época em que os exemplares situados no Centro, erguidos no tempo do Império, começavam a desaparecer, enquanto os exemplares residenciais eruditos contemporâneos, mesmo quando chamados de chalets, apresentavam composições arquitetônicas bem mais elaboradas que as dos chalés antigos, e evitavam o uso de lambrequins, por serem então considerados de mau gosto. Anônimo. Chalé a ser construído na avenida Paulista, esquina da rua Bela Cintra, para Nestore Fortunati, 1902. Desenho técnico. Acervo do Arquivo Histórico Municipal, São Paulo. Reprodução de José Rosael. 


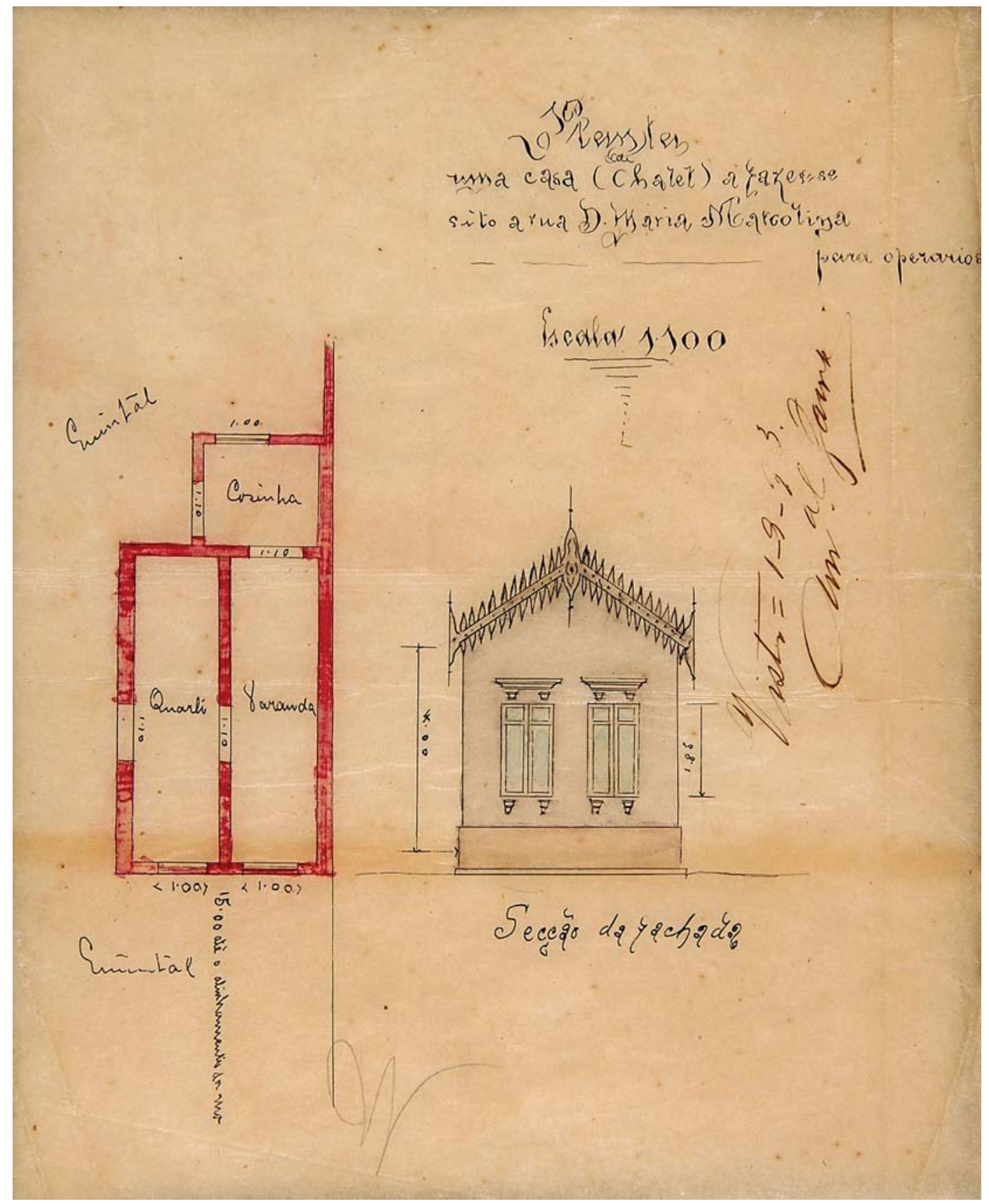

Figura 36 - Anônimo. Projeto de chalé para moradia de operários, 1893 (VII.A.43). Acervo do Arquivo Histórico Municipal, São Paulo. Reprodução de José Rosael. 


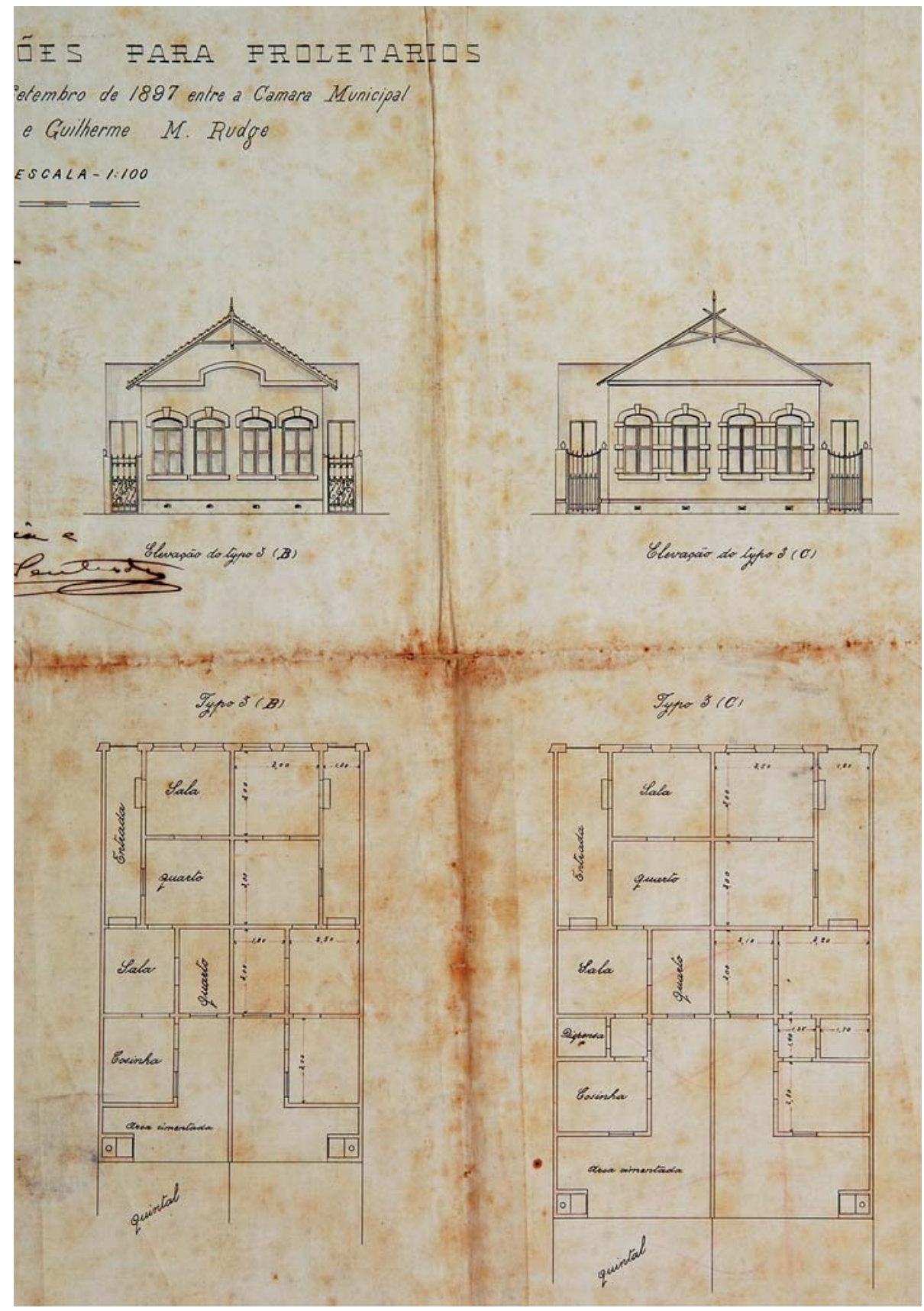

Figura 37 - Anônimo. Projetos de chalés para moradia de operários, datados de 1898, (VII.A.9). Acervo do Arquivo Histórico Municipal, São Paulo. Reprodução de José Rosael. 
93. Bangalôs, ou antes, bungalows, em inglês, eram pequenas construções domésticas, de um só pavimento, de remota origem indiana (região de Bengala), adaptadas pelos colonizadores ingleses no século XVIII para suas residências de verão. Esse tipo de edificação chegou aos EUA na segunda metade do século XIX, já adaptado ao Ecletismo, e aí floresceu desde então. No início do $\mathrm{XX}$, caracterizava-se por ser uma habitação pitoresca, de um só piso sobre porão, despretensiosa e informal como todo o cottage, e muitas vezes apresentava pórtico frontal e empenas de chalé. Nos EUA há vários tipos e estilos de bangalôs, mas o mais popular, ou mais notável, é o que aderiu ao estilo Arts and Crafts. Em São Paulo, já havia bangalôs no princípio da década de 1910 e seu auge foi atingido durante os anos de 1920 a 1950.

94. Sobre essa casa, ver também foto de autoria de Guilherme Gaensly \& Lindemann, tirada do Album Lembrança de São Paulo,c.18961900, reproduzida em Ima gens de São Paulo (2001, p. 10-11). À extrema esquerda da foto, vê-se a vila de Adam von Büllow, presidente da Companhia Antarticta, com uma empena de chalé, de madeira, belamente decorada e executada, sobrepujando a varanda do primeiro andar, sob a qual se achava a entrada principal da residência. 95. Ver SÃO PAULO (Cidade) (Obras particulares, v. 419).

96. Idem (Obras públicas, VIII.H.12).

97. Idem.VII. F.1-A um ou outro corpo saliente da construção, ao lado de outras tantas soluções de telhado, vernáculas ou historicistas, que, de maneira eclética, conviviam no mesmo edifício.

Esquadrinhando fotos panorâmicas de autoria de Guilherme Gaensly, por exemplo, tomadas no início do século XX, e tendo por tema os bairros de Santa Cecília e Vila Buarque, ou examinando imagens da mesma época que focalizam os bairros de Higienópolis ou da Liberdade, vamos encontrar inúmeras construções com empenas desse tipo. De fato, ainda hoje nos deparamos nas ruas da cidade com algumas antigas habitações que conservam decorações bastante fantasiosas em suas empenas. São reminiscências de tipo suíço, como é o caso do bangalô ${ }^{93}$ (c. 1910) em que habitou o dr. Francisco Franco da Rocha (1864-1933), na esquina da rua desse nome com Homem de Mello, em Perdizes (Figuras 38 e 39). Também em mansões situadas na avenida Paulista, eventualmente, ocorriam tetos com elementos de madeira trabalhada, compondo decoração livremente inspirada nos chalés e a sobrepujar partes importantes das fachadas, mas, da mesma forma, nelas já não havia lambrequins. Podemos exemplificar esses casos com a vila de Adam von Büllow, de 1895, de autoria de August Fried ${ }^{94}$, ou com a casa projetada por Guilherme von Ë̈e, em 1905, para o sr. João Kück ${ }^{95}$ (Figuras 40 e 41 ).

Por outro lado, durante os primeiros anos da administração do prefeito Antônio Prado, foram executados, ou ao menos projetados alguns significativos exemplares de arquitetura recreativa, de gosto pitoresco, que insistiam no formalismo tradicional dos chalés. Muitos deles com decoração feita à custa dos repisados lambrequins. Até hoje se observa, no Jardim da Luz, o antigo Quiosque Bavária (depois chamado Ponto Chic), de 1903, com planta octogonal, telhado com beirais guarnecidos de lambrequins, e varandas feitas de madeira recortada, formando intricados desenhos. Próximo dele, porém, existe uma construção contemporânea, a chamada Casa do Administrador, há pouco restaurada, em que a empena de chalé, com beirais sustentados por discretas mãos-francesas, evita a presença desses ora malvistos ornatos recortados. No projeto da praça da República de 1901, não executado e de autoria do engenheiro civil Carlos de Serico ${ }^{96}$ (Figuras 42A a 42D), vemos pavilhões de tiijolos aparentes e telhados de chalé, enfeitados com lambrequins e pináculos. Mas no plano para um estabelecimento de banhos e natação a ser instalado numa grande construção flutuante de madeira prevista para o rio Tietê, de autoria do engenheiro austríaco Robert von Krompholz, de 1902, as portas de ingresso estavam protegidas por pórticos com telhados de chalé, desprovidos dos indesejáveis lambrequins ${ }^{97}$ (Figuras 43A e 43B).

No parque da Cantareira, junto dos reservatórios de água, persistiam edículas cobertas com o característico telhado lambrequinado. A mesma coisa se repetia em construções existentes no bosque da Saúde, no parque Antártica e até em clube de regatas privado à beira do Rio Tietê (Clube Espéria). Constatase, porém, que a extrema popularidade do rendilhado de madeira havia motivado o total aviltamento desse elemento decorativo. Pois, agora, apresentavam-se engalanados com lambrequins até as construções mais ínfimas e os mais banais 

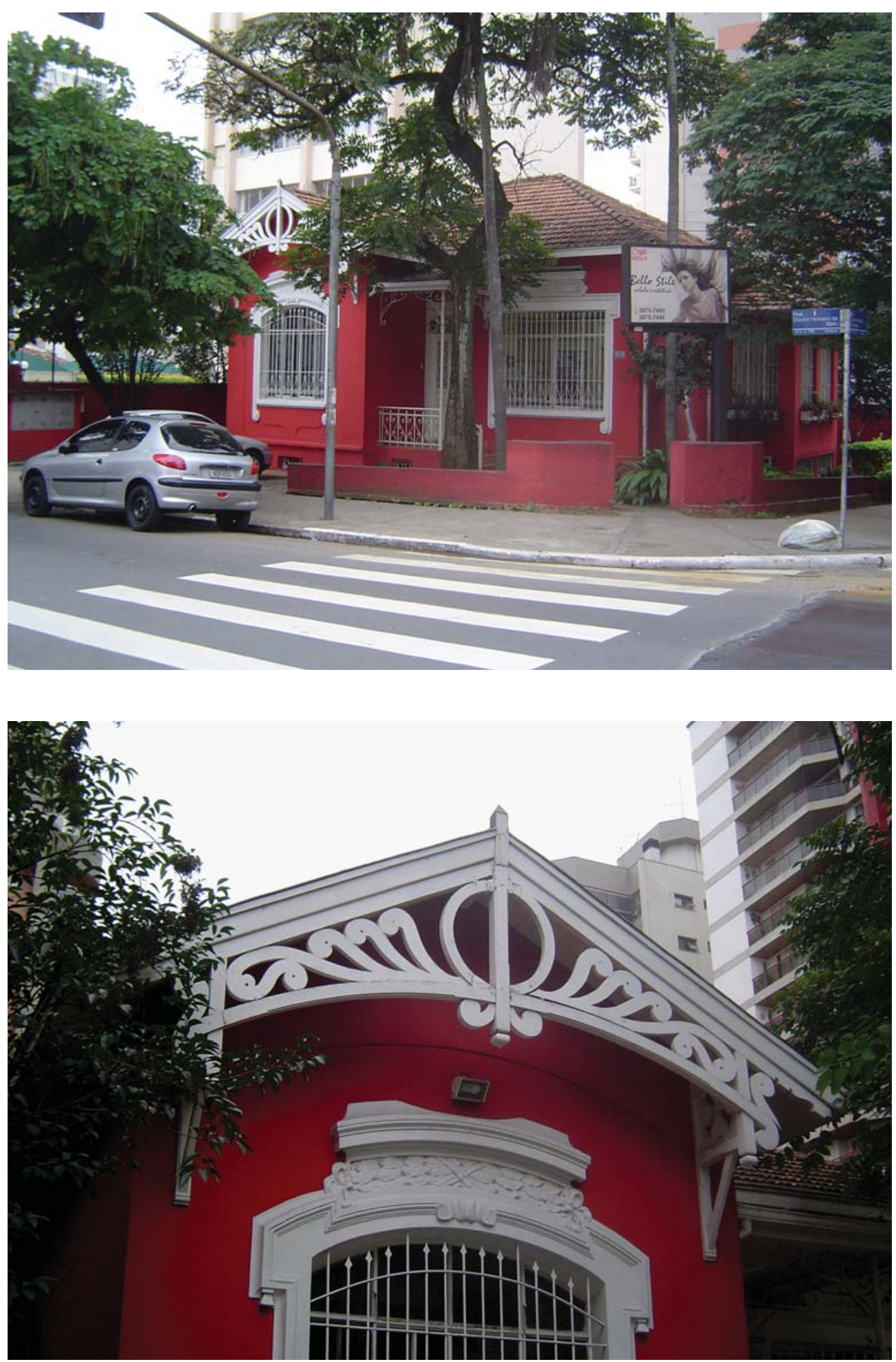

Figuras 38 e 39 - Bangalô (c. 1910) onde morou dr. Francisco Franco da Rocha, em Perdizes. No detalhe, empena de chalé. Fotografias de Paulo César Garcez Marins. 


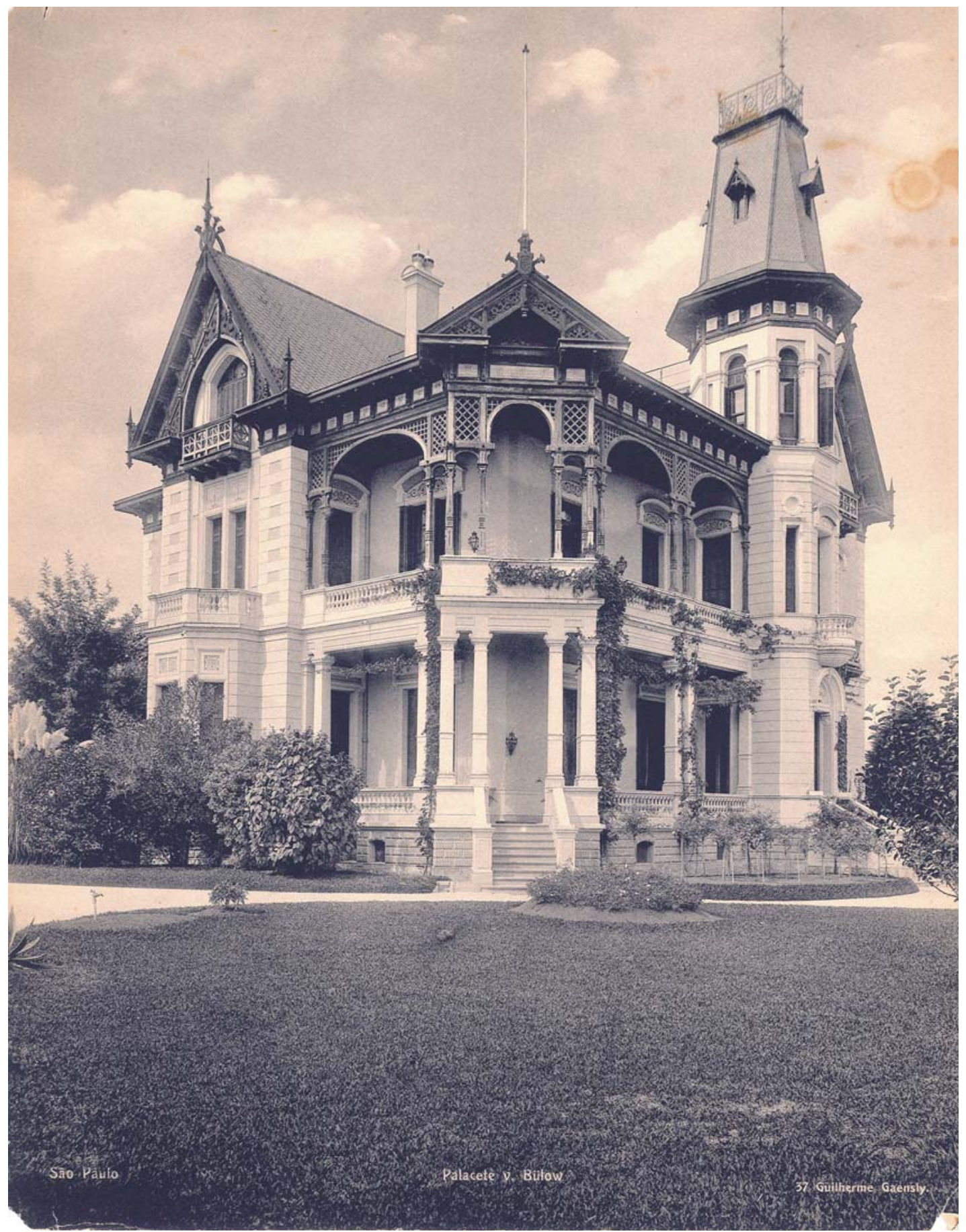

Figura 40 - Transformada em mero detalhe arquitetônico, a empena de chalé, neste projeto, restringe-se a assinalar a entrada principal da casa. Notar que as outras duas empenas da construção, embora apresentando os mesmos ornatos de madeira, denotam inspiração medievalizante, graças ao ângulo agudo dos telhados. GuiIherme Gaensly \& Lindemann. Vila Von Büllow (1 895), de autoria de August Fried. Fotografia, c. 1896-1900. Acervo Biblioteca da Faculdade de Arquitetura e Urbanismo da USP, São Paulo. 


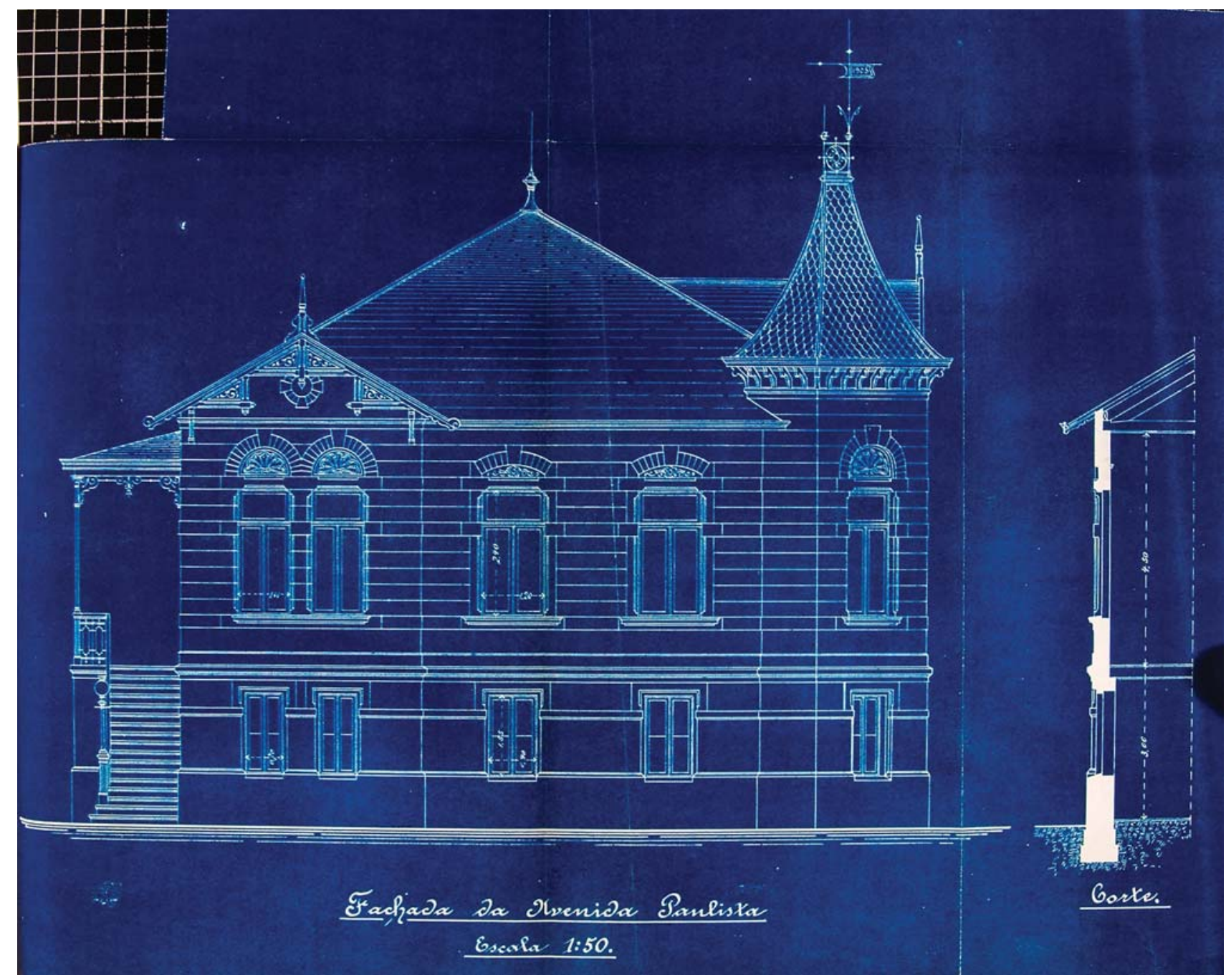

Figura 41 - Aqui, a típica empena de chalé coroa um corpo avançado, que se destaca da fachada principal. Solução característica dos chalés de fins do século XIX e do início do seguinte. Digna de nota neste exemplar, como em outros projetos eruditos contemporâneos, é a ausência de lambrequins. Anônimo. Projeto residencial de Guilherme von Eÿe, 1905. Desenho técnico. Acervo do Arquivo Histórico Municipal, São Paulo. Reprodução de José Rosael. 


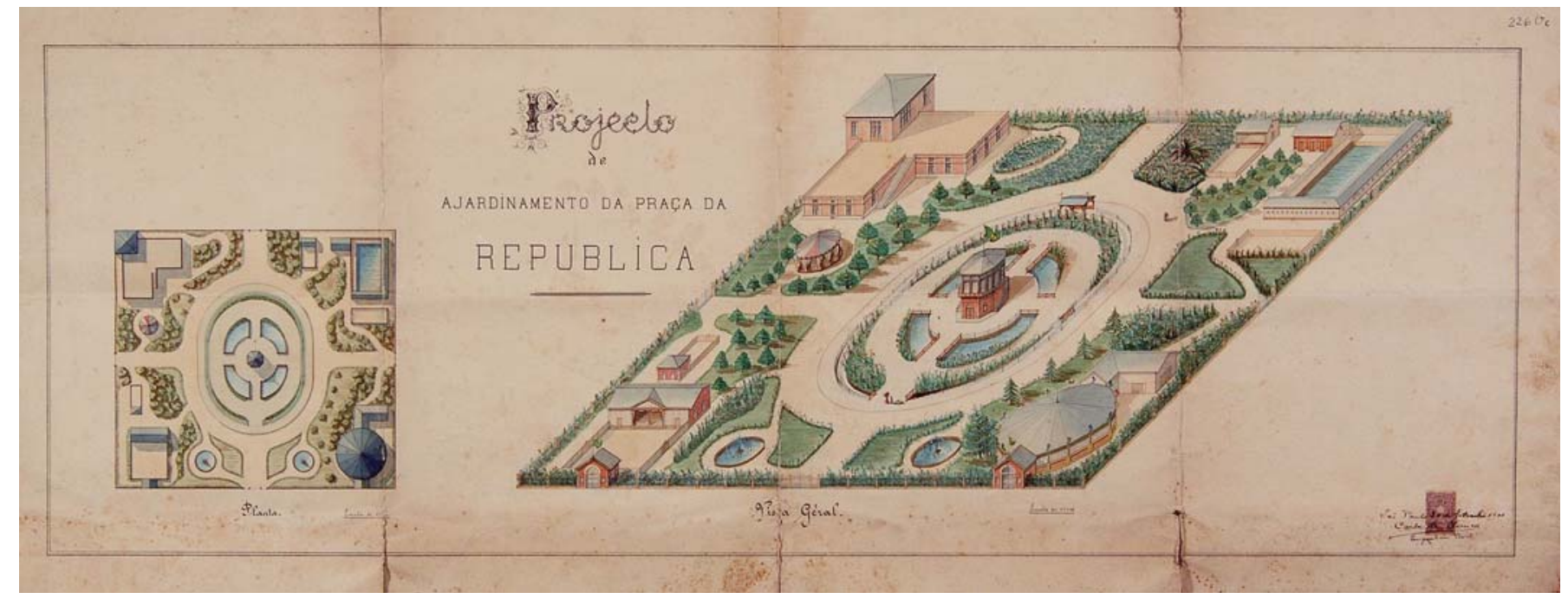

Figura 42A - Anônimo. Projeto da praça da República, de autoria do engenheiro Carlos de Serico, 1901 . Perspectiva aquarelada. Acervo do Arquivo Histórico Municipal, São Paulo. Reprodução de José Rosael.

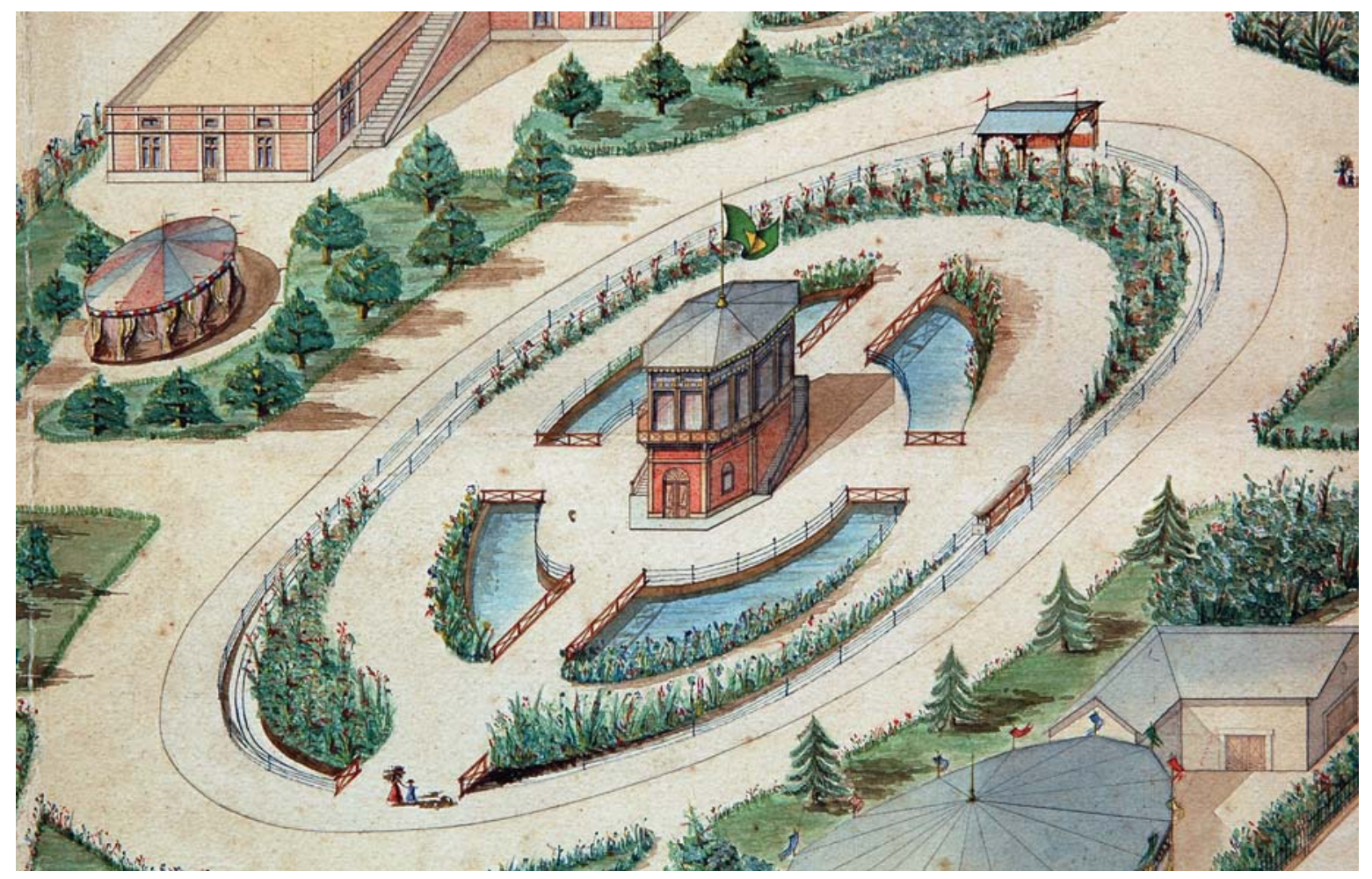

Figura 42B - Coreto com telhado lambrequinado. Detalhe da Figura 42A. Reprodução de José Rosael. 


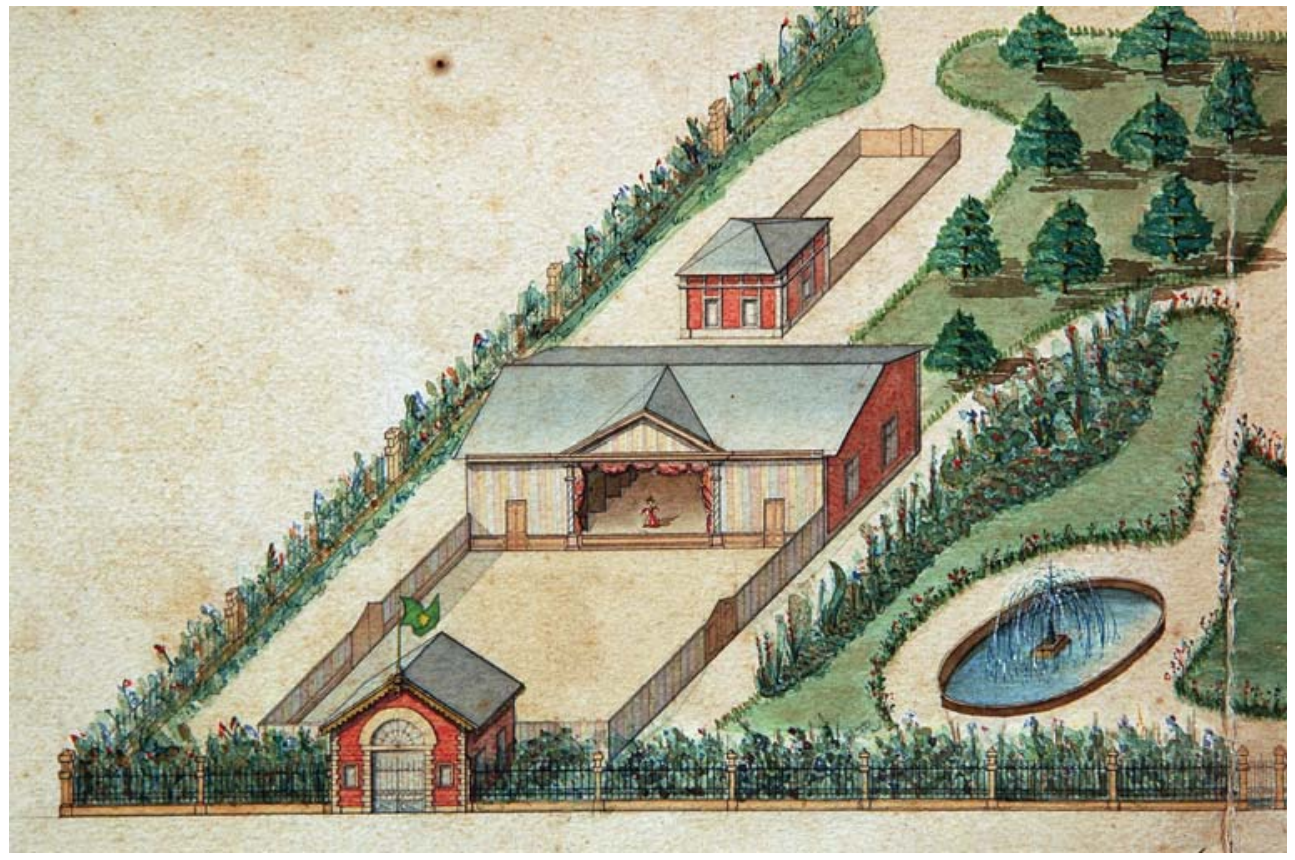

Figura 42C - Teatro com acesso protegido por telhado lambrequinado. Detalhe da Figura 42A. Reprodução de José Rosael.

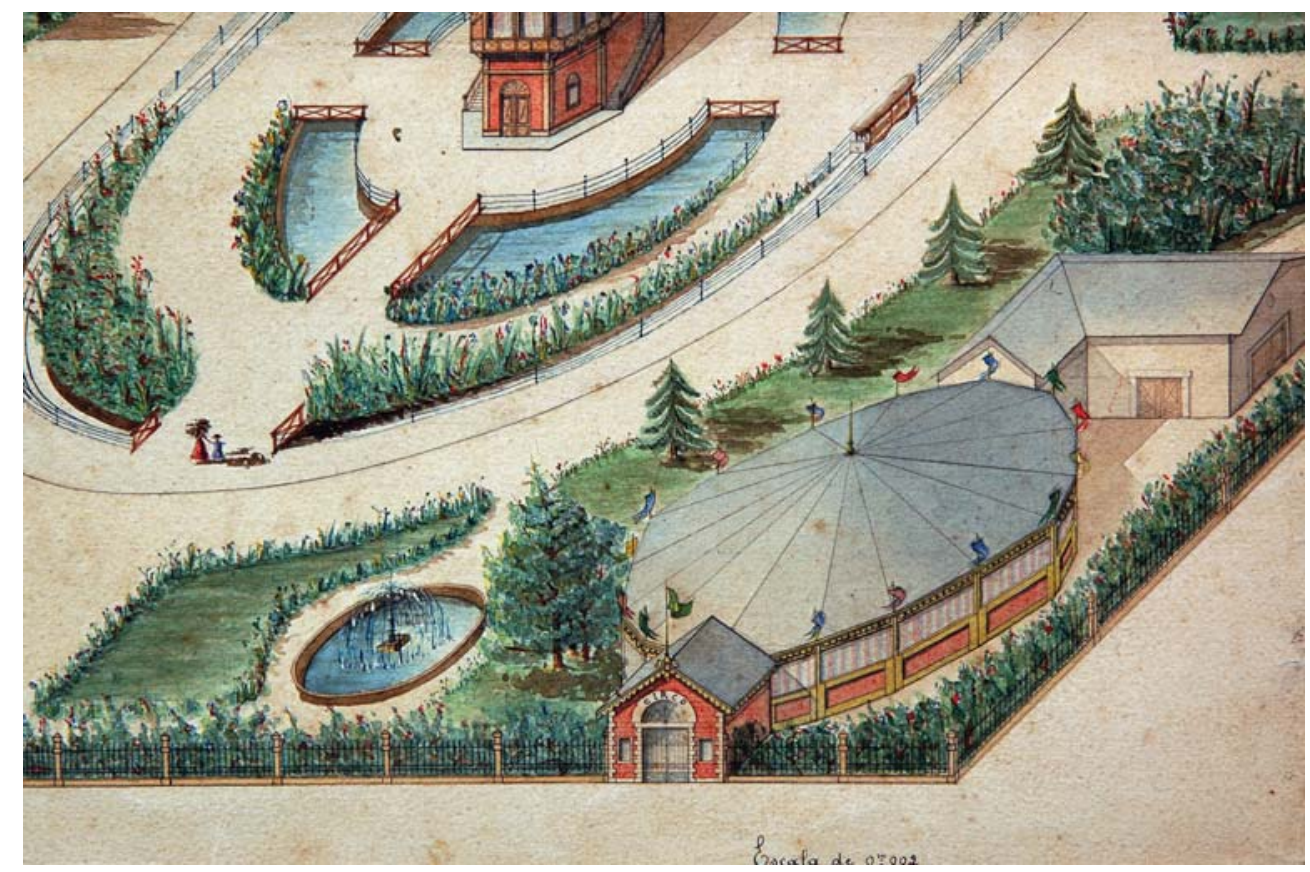

Figura 42D - Circo, com acesso coberto por telhado lambrequinado. Detalhe da Figura 42A. Reprodução de José Rosael. 


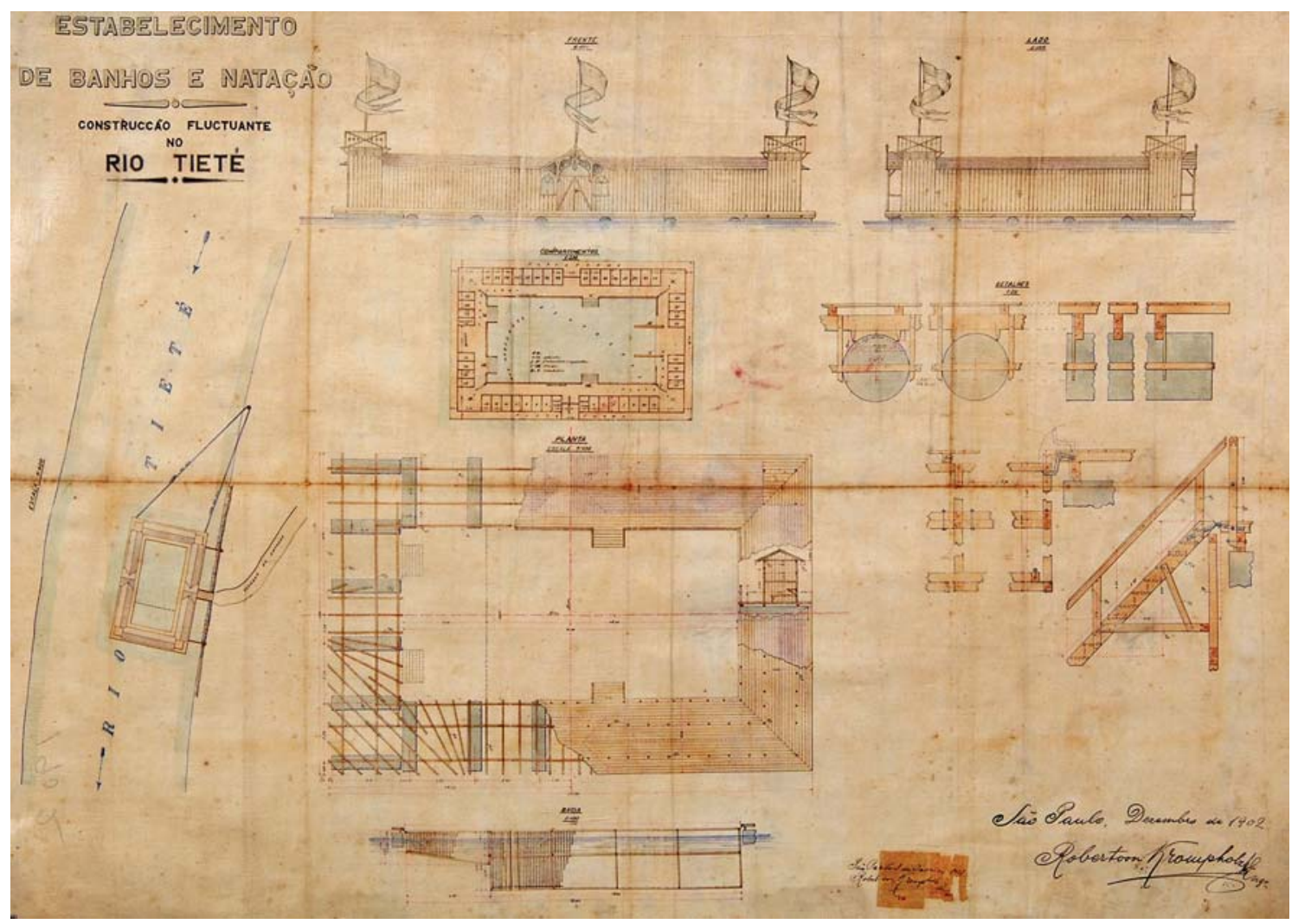

Figura 43A - Anônimo. Projeto de estabelecimento de banhos e natação, de autoria do engenheiro Robert von Krompholz, 1902. Desenho técnico. Acervo do Arquivo Histórico Municipal, São Paulo. Reprodução de José Rosael.

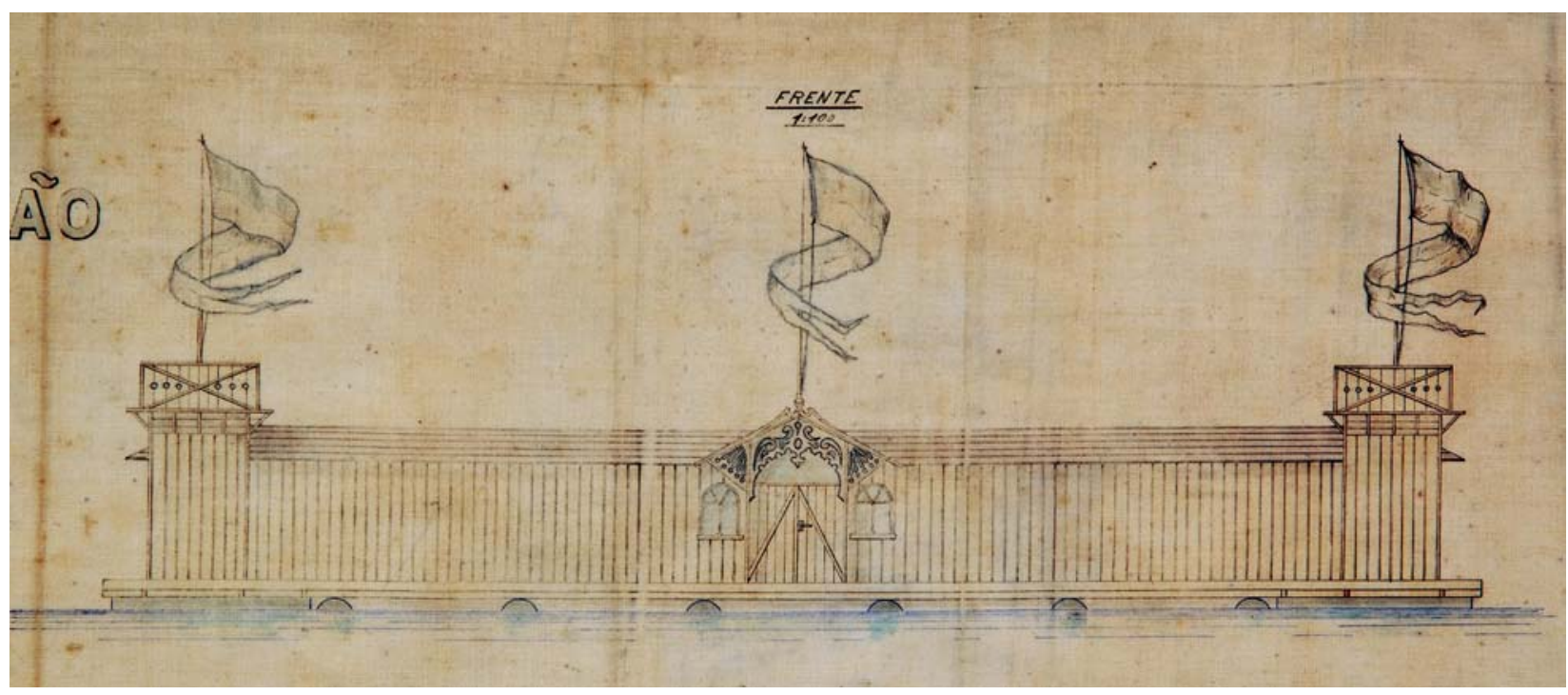

Figura 43B - Nos pórticos do estabelecimento de banhos viam-se empenas de chalé muito ornamentadas, mas desprovidas de lambrequins. Detalhe da Figura 43 A. Reprodução de José Rosael.Rosael. 
exemplares de mobiliário urbano, tais como, estações de trem suburbano, sanitários públicos, quiosques, coberturas de pontos de bondes, guaritas, etc.

Os chalés humildes - erguidos em bairros populares distantes, como Brás ou Mooca - resistiram certamente por muito mais tempo que os seus equivalentes eruditos situados em bairros ricos. Yan de Almeida Prado garantia, em 1960, que ainda restavam alguns exemplares de chalé espalhados pela avenida Rangel Pestana, na rua Piratininga e na rua do Gasômetro ${ }^{98}$. Mas não é de nosso conhecimento que tenha algum deles chegado até os dias de hoje. Diante desse quadro de avassaladora destruição, assume um status peculiar o sobrado achalezado existente na rua Roberto Simonsen, atualmente de propriedade da Secretaria Municipal de Cultura, ao qual já nos referimos. Embora do ponto de vista técnico não possa ser considerado um chalé genuíno, é hoje, a única testemunha de uma moda que vigorou intensamente em São Paulo há cerca de 130 anos atrás.

\section{REFERÊNCIAS}

\section{A. DOCUMENTAÇÃO PRIMÁRIA MANUSCRITA}

SÃO PAULO (Cidade). Arquivo Histórico Municipal Washington Luís (AHMWL). Livros de lançamento dos autos de alinhamento, v. 0376;0480;0481.

SÃO PAULO (Cidade).Arquivo Histórico MunicipalWashington Luís (AHMWL).Obras particulares, v. 021-128.

SÃO PAUlO (Estado).Arquivo Público do Estado. Obras Públicas. Correspondência de Serafim Corso ao presidente da Província, em que solicitava dilatação do prazo para a entrega das obras da fonte do largo de Palácio. 1 abr. 1886. Ordem 5195.

B. DOCUMENTAÇ̃̃O PRIMÁRIA IMPRESSA

SÃO PAULO (Cidade).Atas da Câmara da cidade de S.Paulo, 1873, v.49. São Paulo:Departamento de Cultura, 1948.

.Atas da Câmara da cidade de S. Paulo, 1880, v. 61. São Paulo: Departamento de Cultura, 1949.

\section{DOCUMENTAÇ̃̃o CARTOGRÁFICA}

SÃo PAUlO (Cidade). Comissão do IV Centenário da Cidade de São Paulo. São Paulo antigo: plantas da cidade. Planta n. 9. São Paulo, 1954. 1 mapa. Sem escala.

.Mappa topographico do Municipio de São Paulo: folha 51/12. São Paulo: SARA Brasil, 1930. 1 mapa. Escala 1:1000. 
D. ANÚNCIOS DE JORNAIS

ALTO negocio. Correio Paulistano, São Paulo, p. 4, 28 maio 1885.

ALUGA-SE. Correio Paulistano, São Paulo, p. 4, 1 maio 1885.

ANNUNCIOS - terrenos. Correio Paulistano, p. 3, São Paulo, 27 fev. 1878.

AVISOS - Construcção de chalets. Correio Paulistano, p. 3, São Paulo, 1 fev. 1878.

CARPINTARIA a vapor. Correio Paulistano, p. 3, São Paulo, 3 abr. 1881.

CARPINTEIRO francez. Correio Paulistano, p. 4, São Paulo, 11 out. 1861.

CASA de Saude. Diario Popular, p. 4, São Paulo, 30 dez. 1891.

EMPRESA Paulista de Eletricidade. Diario Popular, p. 2, São Paulo, 6 dez. 1888.

FABRICA de Santo Antonio. Correio Paulistano. p. 2, São Paulo, 26 jun. 1877

TELHAS francezas. Correio Paulistano.p. 3, São Paulo, 27 abr. 1877.

UTIL e rendoso emprego de capital. Correio Paulistano. p. 4, São Paulo, 21 jan. 1881.

VENDE-SE. Correio Paulistano, p. 4, São Paulo, 22 set. 1877.

E. REFERÊNCIAS BIBLIOGRÁFICAS

A CAPITAL paulista commemorando o centenario da Independencia. São Paulo: Sociedade Editora Independencia, 1920.

ALMANACH administrativo, commercial e industrial da Provincia de S. Paulo para o anno de 1885. São Paulo: Jorge Seckler, 1884.

ALMANACH administrativo, commercial e industrial da Provincia de S. Paulo para o anno de 1886. São Paulo: Jorge Seckler, 1886.

ALMANACH administrativo, commercial e industrial da Provincia de S. Paulo para o anno de 1887. São Paulo:Jorge Seckler, [1887?].

ALMANACH administrativo, commercial, industrial da Provincia de S. Paulo para o anno de 1888, 6. anno. São Paulo: Jorge Seckler, [1888?].

AMERICANO, Jorge. São Paulo naquele tempo, 1895-1915. São Paulo: Melhoramentos, 1957.

BRENNA, Giovanna Rosso del. Ecletismo no Rio de Janeiro (séc.XIX-XX). In: FABRIS,Annateresa (org.). Ecletismo. São Paulo: Nobel; Edusp, 1987.

BRUNO, Ernani Silva.Memória da cidade de São Paulo: depoimentos de moradores e visitantes, 1953-1958. São Paulo: Departamento do Patrimônio Histórico, 1981.

CAMPOS, Eudes. Arquitetura paulistana sob o Império: aspectos da formação da cultura burguesa em São Paulo. 1997.814 f.Tese (Doutorado em Arquitetura) - Faculdade deArquitetura e Urbanismo da Universidade de São Paulo, São Paulo, 1997.4 v.

Nos caminhos da Luz, antigos palacetes da elite paulistana. Anais do Museu Paulista: história e cultura material, São Paulo, n. 1, v. 13, p. 11-57, jan.-jun. 2005. 
DINIZ, Firmo de A. (Junius). Notas de viagem. São Paulo: Governo do Estado de São Paulo, 1978.

DOWNING,A. J. The architecture of the country bouses. New York: Dover, [1969].

FREYRE, Gilberto. Ordem e Progresso, v. 1. Rio de Janeiro: José Olympio, 1959, 2 v.

HOMEM, Maria Cecília Naclério \& MACHADO, Lúcio Gomes (coord.). Vila Penteado. São Paulo: FAU-USP, 1976.

IL BRASILE e gli italiani. Firenze: R. Bemporad \& Filho, [1907].

IMAGENS de São Paulo: Gaensly no acervo da Light, 1899-1925. São Paulo: Fundação Patrimônio Histórico da Energia de São Paulo, 2001.

KOENIGSWALD, Gustavo. São Paulo. São Paulo; s.n., 1895.

LAGO, Pedro Corrêa do. Iconografia paulista do século XIX. São Paulo: Metalivros, 1998.

LERNER, Dina; BITTENCOURT, Marcos (coord.). Patrimônio cultural: guia dos bens tombados pelo Estado do Rio de Janeiro, 1965-2000. Rio de Janeiro: Inepac, 2005.KOENIGSWALD, Gustavo. São Paulo. São Paulo: [s.n.] 1895.

KOSERITZ, Carl von. Imagens do Brasil. Belo Horizonte: Itatiaia; São Paulo: Edusp, 1980.

LAMERS-SCHÜTZE, Petra (coord.).Teoria da Arquitectura: do renascimento até nossos dias. Trad. Maria do Rosário Paiva Boléo. Köln:Taschen, 2003.

MARTINS,Antônio Egídio. São Paulo antigo (1554 a 1910). São Paulo: Conselho Estadual de Cultura, 1973.

MIDDELTON, Robin;WATKIN, David. Architettura dell'Ottocento, 1. Milano: Electa, 1980.

MIGNOT, Claude. L'Architecture au XIX ${ }^{e}$ siécle. Friburg: Office du Livre, 1983.

SANT'ANNA, Nuto. São Paulo Histórico, v. 4. São Paulo: Departamento de Cultura, 1937-1944. 6 v.

SALMONI, Anita; DEBENEDETTI, Emma. Arquitetura italiana em São Paulo. São Paulo: Perspectiva, 1981.

SÃO PAULO (Cidade). AHMWL. São Paulo em reconstrução: o centro da cidade entre $1899 \mathrm{e}$ 1914. São Paulo: 2003 (Inédito)

SÃO PAULO (Estado). São Paulo em três tempos. São Paulo: Imesp, 1982.

SESSO JR., Geraldo. Retalbos da velha São Paulo. São Paulo: Gráfica Municipal de São Paulo, 1983.

SEVERO, Ricardo.A arte tradicional no Brasil. Revista do Brasil, São Paulo, v. 4, p. 394-424, jan.abr. 1917.

SOCIETÉ DE PUBLICITÉ SUD-AMERICAINE MONTE DOMECQ ET CIE. O Estado de São Paulo. Barcelona:Thomas, 1918.

PRADO, J. F. de Almeida (Yan de Almeida Prado) Apontamentos para a história da arquitetura em São Paulo. In: GFAU. Depoimentos I. São Paulo: GFAU, 1960. p. 11-26. 
PRADO, J. F. de Almeida (Yan de Almeida Prado) Arquitetos de São Paulo em 1880. Habitat, São Paulo, n.3, p. 50-53, 1951.

S. Paulo antigo e sua arquitetura. Illustração brasileira, Rio de Janeiro, anno X, n. 109, [s.p.], set. 1929 .

PEVSNER, Nikolaus. Studies in Art, Architecture and Design. Vol. 1. London:Thames and Hudson, 1969. 2 vol.

TELLES, Pedro C. S. História da engenharia no Brasil, séc. XVI a XIX. Rio de Janeiro: Livros Técnicos e Científicos, 1984.

VASQUEZ, Pedro Karp. Álbum da Estrada União e Indústria. 2. ed. Rio de Janeiro: Quadratim G, 1998.

\section{F. DOCUMENTAÇÃO ELETRÔNICA}

CARLOS Botelho. Disponível em:<http://br.geocities.com/weber_ruiz/carlos_botelho.html > Acesso em: mar. 2008.

CRÊTE de faîtage em terre cuite. Disponível em:<http://grau.club.fr/cretedefaitage/aiguillecr. html>.Acesso em: set. 2007.

OSBOURNE House. Disponível em: <http://en.wikipedia.org/wiki/Osborne_House>.Acesso em: fev. 2008.

SHARAWAGGI. Disponível em: <http://.www.languagehat.com/archives/001729.php > Acesso em: fev. 2008.

RUSKIN, John. The Poetry of Architecture (1838). Disponível em: <http://www.gutenberg.org/ etext/17774>.Acesso em: fev. 2008.

RUSKIN, John. Lectures on Architecture and Painting (1853). Disponível em: <http://www. gutenberg.org/etext/23593>.Acesso em: fev. 2008.

\section{G. DOCUMENTAÇÃO FOTOGRÁFICA}

AZEVEDO, Militão Augusto de. Album comparativo da cidade de São Paulo, 1862-1887. Acervo do Museu Paulista da USP, São Paulo.

\section{H. ENTREVISTA}

Concedida ao autor pela pesquisadora Maria Lucia Mott, do Museu da Saúde Emílio Ribas, em março de 2008.

Artigo apresentado em 3/2008. Aprovado em 4/2008. 